\title{
Environmental Report of Purex Plant and Uranium Oxide Plant - Hanford Reservation
}

Richland, Washington

Safety and Environmental Engineering Analysis Department

April 1979

MASTER

Prepared for the United States

Department of Energy

Under Contract EY-77-C-06-1030

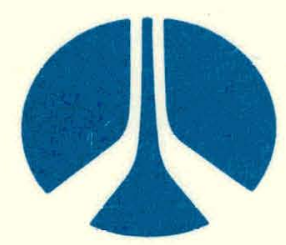

Rockwell International

Rockwell Hanford Operations

Energy Systems Group

Richland, WA 99352 


\section{DISCLAIMER}

This report was prepared as an account of work sponsored by an agency of the United States Government. Neither the United States Government nor any agency Thereof, nor any of their employees, makes any warranty, express or implied, or assumes any legal liability or responsibility for the accuracy, completeness, or usefulness of any information, apparatus, product, or process disclosed, or represents that its use would not infringe privately owned rights. Reference herein to any specific commercial product, process, or service by trade name, trademark, manufacturer, or otherwise does not necessarily constitute or imply its endorsement, recommendation, or favoring by the United States Government or any agency thereof. The views and opinions of authors expressed herein do not necessarily state or reflect those of the United States Government or any agency thereof. 


\section{DISCLAIMER}

Portions of this document may be illegible in electronic image products. Images are produced from the best available original document. 


\title{
Q1
}

\section{Rockwell International}

\author{
Rockwell Hanford Operations \\ Energy Systems Group \\ Richland, WA 99352
}

\author{
PREPARED FOR THE UNITED STATES DEPARTMENT OF ENERGY \\ UNDER CONTRACT EY-77-C-06-1030
}

\section{PRELIMINARY REPORT}

This is a report prepared by Rockwell Hanford Operations for the U. S. Department of Energy to present currently available information on the Purex and Uranium Oxide plants and their environs. The report does not include complete engineering and safety analyses required before startup can be authorizod, nor is it reprasanter tn fullfill the regulatinns of the Conunsil on Environmental Quality which implement provisions of the National Envirurimental Policy Act.

NOTICE

This Report was prepared as an account of work sponsored by the United States Government. Neither the United States nor the United States Department of Energy, nor any of their Employees, nor any of their Contractors, Subcontractors, or their Employees, makes any warranty, express or implied, or assumes any legal liability or responsibility for the accuracy, completeness, or usefulness of any information, apparatus, product or process disclosed, or represents that its use would not infringe privately owned rights. 
ENVIRONMENTAL REPORT OF PUREX PLANT

AND URANIUM OXIDE PLANT -

HANFORD RESERVATION, RICHLAND, WASHINGTON

April 1979

Prepared for the United States

Department of Energy

Under Contract EY-77-C-06-1030

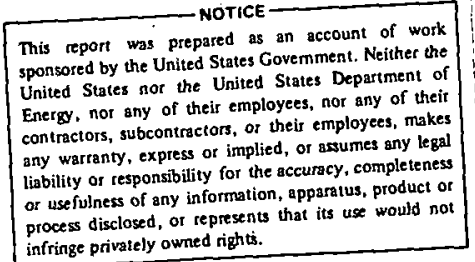

Rockwell International

Rockwell Hanford Operations

Energy Systems Group

Richland, Washington 99352 
Issue Approval:
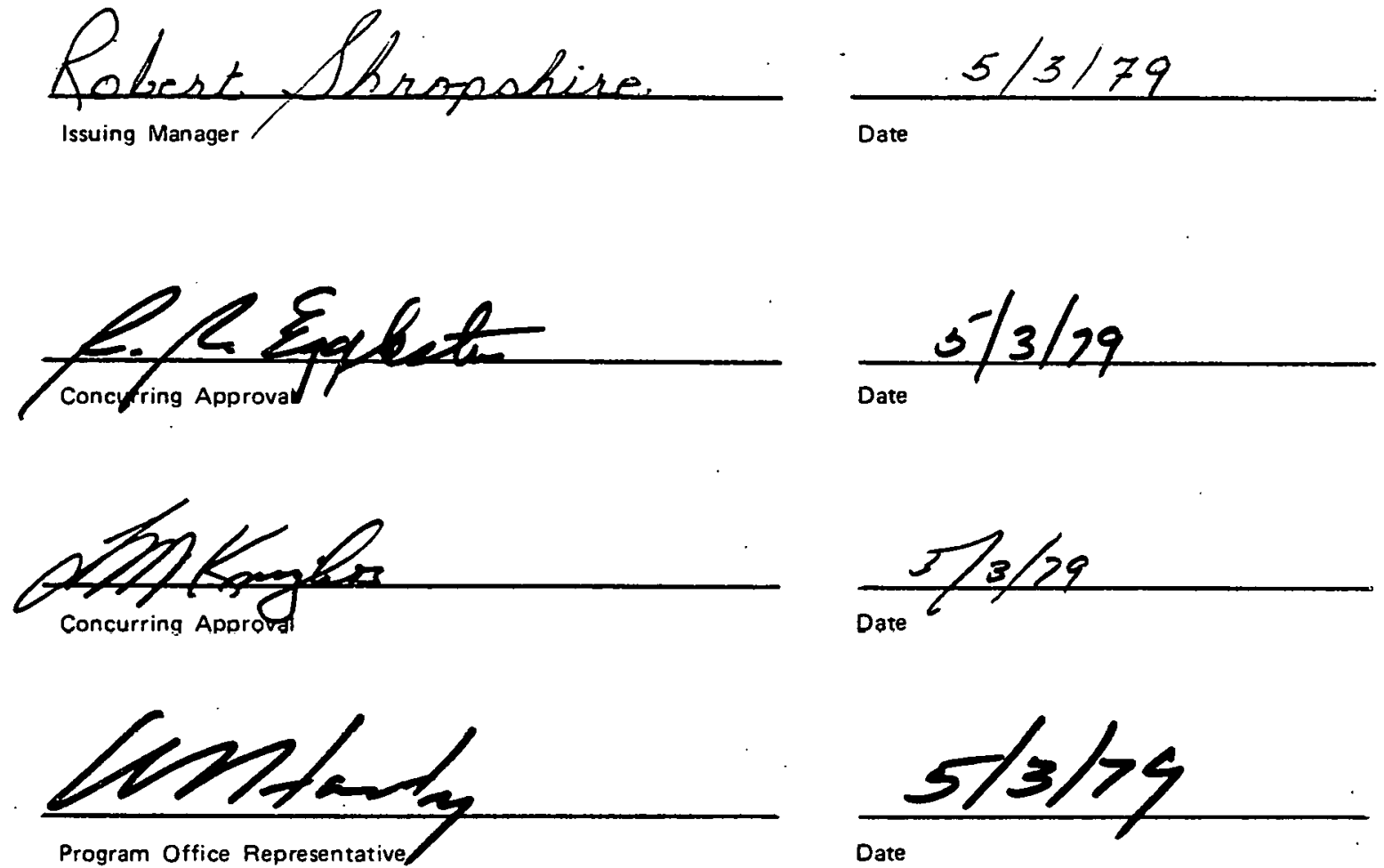
RHO-CD-742

FOREWORD

This environmental report presents the impacts of operating the Purex and Uranium 0xide Plants to support potential $N$ Reactor operation through 1990. In December 1975, the Energy Research and Development Administration issued ERDA-1538, a final environmental impact statement of waste management operations, Hanford Reservation, Richland, Washington. ERDA-1538 reassessed the environmental impacts associated with the continuation of the Hanford Waste Management Program.

In ERDA-1538, extensive historical, site, construction, programmatic, impact, alternatives and other data were presented which were pertinent to the operation of the facilities covered in this report. A concerted effort has been made in preparing this document to eliminate redundancy and unnecessary material by referencing the applicable data contained in ERDA-1538. Where appropriate for continuity or for the convenience of the reader, some material has been extracted from ERDA-1538 and included. The discussion of environmental effects resulting from the continued operation of these production facilities updates the data presented in ERDA-1538. Potential environmental impacts are expected to be reduced as the planned modifications are implemented. 
THIS PAGE

\section{WAS INTENTIONALLY}

\section{LEFT BLANK}




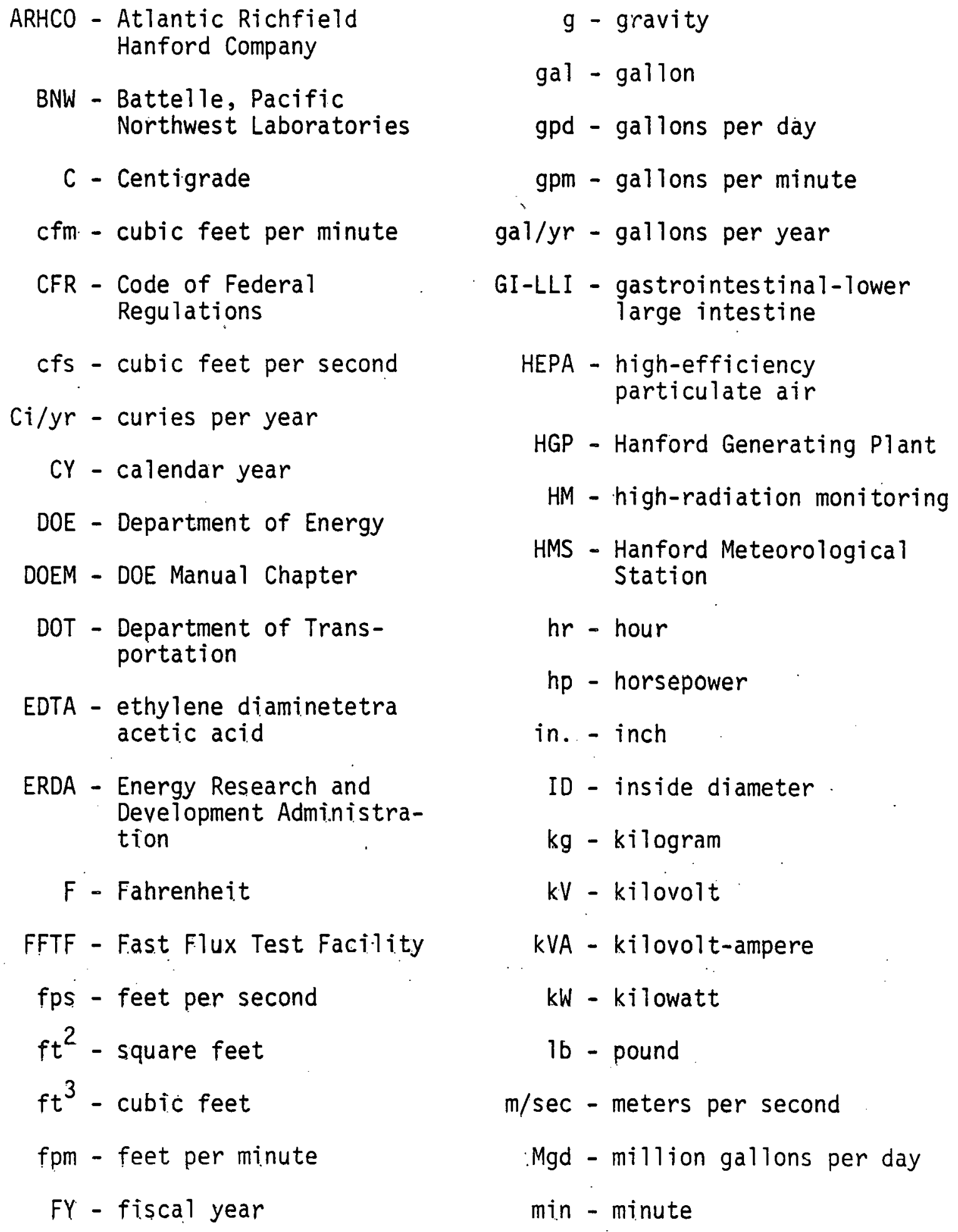




\section{LIST OF ABBREVIATIONS (Continued)}

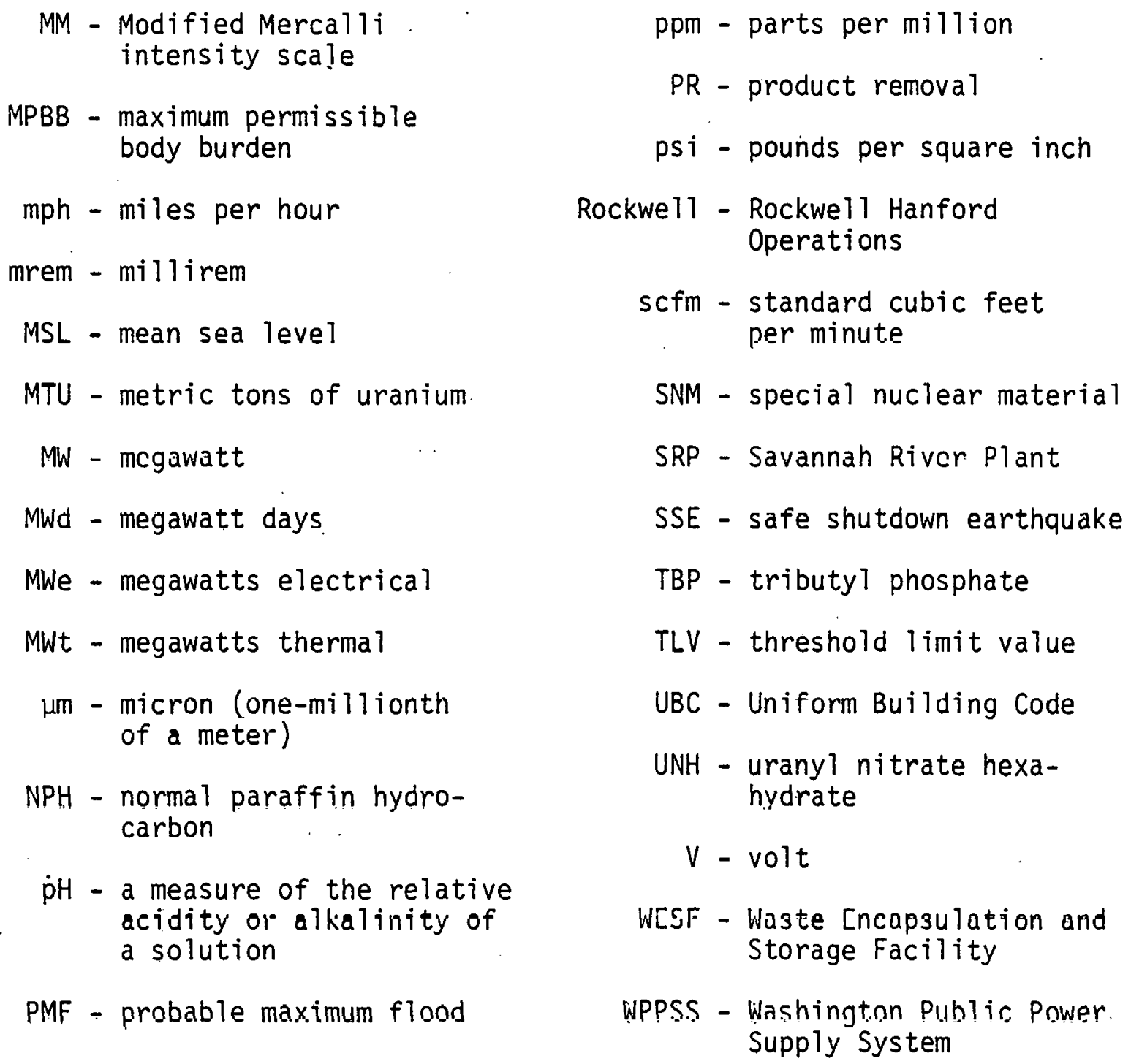


I. SUMMARY ...................... I- . . . .

I.1 DESCRIPTION OF SITE, PROGRAM AND FACILITIES ..... I-

I.2 ENVIRONMENTAL EFFECTS ............... I-4

I.2.1 Routine Operations .......... I-4

I.2.2 Effects of Postulated Accidents ..... I- I-5

II. DESCRIPTION OF SITE, PROGRAM AND FACILITIES ......... . II- I

II.1 CHARACTERIZATION OF EXISTING ENVIRONMENT ...... II-1

II.1.1. Hanford Reservation ........... II-1

II.1.2 Demography and Land Use ......... II-4

II.1.3 Historical and Archaeological Sites... . II-4

II.1.4 Hydrology ............... II-4

II.1.5 Ecology .............. II-5

II.1.6 Meteorology ............ II.-5

II.1.7 Geology and Seismicity ........ II-6

II.2 DESCRIPTION OF PROGRAM ............ II-8

II.2.1 Operational Relationships . . . . . . I II-8

II.2.2 Anticipated Benefits ......... II-12

II.2.3 Safeguards ........... II-13

II.3 DESCRIPTION OF FACILITIES ........... II-16

II.3.1 Purex Plant Facilities ......... II-16

II.3.2 Uranium 0xide Plant Facilities ..... II-61

REFERENCES FOR SECTION II .......... II-82

III. ENVIRONMENTAL EFFECTS . . . . . . . . . . . III-I

III.1 PUREX PLANT . . . . . . . . . . . . . . . TITT-1 T

III.1.1 Radiological Impacts ........... III-1

III.1.2 Nonradiological Impacts .......... III-10

III.1.3 Natural Forces. . . . . . . . . . . . III-16

III.1.4 Accident Impacts ......... III-19

REFERENCES FOR SECTION III . . . . . . . . III-7I

FIGURES:

II.1 Location of DOE Hanford Reservation Showing 50-Mile Radius From Hanford Meteorological Station (HMS) . . . II-2

II.2 Map of Hanford Reservation ............ II-3

II.3 Earthquake Zones of Washington . . . . . . . . II-8

II.4 Delailed Map of the 200 East Area .......... . II-17 


\section{FIGURES: (Continued)}

II.5 The Purex Plant . . . . . . . . . . . . . II-18

II.6 Cross Section and Ventilation Schematic Diagram of the Purex 202-A Building .......... . 11-18

II.7 Plan Views of the Purex 202-A Building. . . . . . . . II-19

II.8 Purex Process Simplified Flow Diagram ........ II-25

II.9 Simplified Schematic Diagram of the Purex Plant Liquid Effluents............ II-42

II.10 Simplified Schematic Diagram of the Purex Plant Gaseous Effluents ........... II-44

II.11 Plan Diagram of the Uranium 0xide Plant Complex .... II-62

II.12 Uranium 0xide Plant . . . . . . . . . . . . . II-63

II.13 Plan View of the Uranium Oxide Plant at Ground Level............... II 65

II.14 Uranium Oxide Process Simplified Flow Diagram . . . . II-66

II.15 Uranium Nitrate Calciner . . . . . . . . . II-69

TABLES:

III.1 Actual and Estimated Annual Liquid Waste Discharges to Cribs From the Purex Plant ............. III-3

III.2 Actual and Estimated Annual Liquid Waste Discharges to Ponds From the Purex Plant ............. III-3

III.3 Actual and Estimated Annual Gaseous Releases From the Purex Plant............ III-5

III.4 Estimated 50-Year Maximum Individual Dose Commitment From the Annual Effluent Release From Purex Plant During the 1972 Period

III.5 Estimated 50-Year Population Dose Commitment From the Annual Effluent Release From Purex Plant During the 1972 Period . . . . . . . . . III-6

111.6. Estimated 50-Year Maxtmum Individudi Dose Conmitment From the Annual Maximum Routine Effluent Release From Future Purex Plant Operation ........ III-7

III.7 Estimated 50-Year Population Dose Commitment From the Annual Maximum Routine Effluent Release From Future Purex Plant. Operation ......... . III-8

III.8 Principal Chemicals Released to Ground via Purex Plant Chemical Sewer............ III-11

III.9 Annual Emission of Pollutants From 200 Area Powerhouses 
TABLES: (Continued)

III.10 Purex Plant Historical Accidents with Potential Environmental Impacts............ III-28

III.11 Purex Plant Radiation Control Experience, 1966-1972 . . . III-31

III.12 Radionuclides Released From Purex Plant During Postulated Dissolving of Short-Cooled Fuel ...... III-33

III.13 Calculated Radiation Doses From Postulated Dissolving of Short-Cooled Fuel ......... III-36

III.14 Radionuclides Released to Environs From Postulated Uranium Fire in Purex Dissolver.......... . III-41

III.15 Calculated Radiation Doses From Postulated Uranium Metal Fire in Purex Dissolver........ III-43

III.16 Radionuclides Released From Postulated Burning Organic Solvent (ICW) ............. III-47

III.17 Calculated Radiation Doses From Postulated Organic Solvent Fire ............. III-48

III.18 Radionuclides Released From Postulated Nuclear Criticality in $1 \mathrm{BX}$ Column ........... III-52

III.19 Calculated Radiation Doses From Postulated Criticality in IBX Column ........... III-53

III.20 Radionuclides Released to Environs From Postulated Cask Car Collision and Uranium Fire........ III-55

III.21 Calculated Radiation Doses From Postulated Cask Car Collision and Uranium Fire ......... III-57

III.22 Actual and Estimated Liquid Waste Releases From the Uranium 0xide Plant . . . . . . . . . III-58

III.23 Actual and Estimated Gaseous Waste Releases From the Uranium 0xide Plant . . . . . . . . . 1II-59

III.24 Historical Accidents in the Uranium 0xide Plant.... . III-64

III.25. Conceivable Accidents Postulated for the Uranium Oxide Plant............. III-65

III.26 Radionuclides Released From Postulated Uranium Oxide Spill ................ III-67

III.27 Calculated Radiation Doses From Uranium Oxide Spill................... III-70 


\section{SUMMARY}

\section{I.1 DESCRIPTION OF SITE, PROGRAM AND FACILITIES}

The semiarid Hanford site occupies about 570 square miles of the southeastern part of the state of Washington. The area has a mild dry climate, and is characterized as a region of low to moderate seismicity. Although there are periods of high winds, tornadoes are rare and tend to be small. The Columbia River passes through the area providing hydroelectric power, irrigation water, salmon and steelhead trout--all of which are of considerable economic importance to the area.

The Purex Plant, the function of which is to separate, recover and purify plutonium, neptunium and uranium from $N$ Reactor irradiated fuel, is located in the 200 East Area, approximately seven miles south of the reactor. The Uranium 0xide Plant, which produces uranium trioxide powder from the uranium nitrate product solution from the Purex Plant, is 10cated in the 200 West Area about five miles west of the Purex Plant. The Purex Plant was constructed during the period 1953 to 1955 with a capital investment of approximately $\$ 77.1$ million. Technological, engineering and operating changes were made in the following years to improve environmental protection, process and equipment reliability, and plant production capacity. Since the end of the most recent operation in 1972 and the issuance of ERDA-1538 in December 1975, additional improvements have been made and/or are planned as discussed on pages II-56 through II-60. No fundamental changes in process flowsheets or operating methods will be made for future operations. Normal methods and the existing system will be used in managing the radioactive wastes described in ERDA-1538. The radioactive material is already in the irradiated fuel before the Purex Plant reprocesses it; Purex Plant operation does not create any new radioactivity. 
The Purex P1ant was operated from 1955 through 1972. Operations were suspended in September 1972, since all available irradiated fuel was reprocessed and only one reactor was still operating. Resumption of the Purex operation has been deferred in a planned manner since 1974 to allow the commitment of additional resources to waste management activities. During the intervening years, the Purex and Uranium Oxide Plants have been maintained in standby condition. The Purex Plant is tentatively scheduled to resume operations in FY 1983, in order to reprocess the fuel inventory which has accumulated since 1972, plus that which will be produced in future $N$ Reactor operation. For overall costeffectiveness, the Purex and Uranium Oxide Plants will be operated in sequence with the waste management facilities. Operation of Purex is needed to provide plutonium for research, reactor development and safety studies, and for national defense programs.

In previous operating years, the Purex final plutonium product has been a nitrate solution which has been converted into plutonium oxide or metal at Z Plant in the 200 West Area for appropriate future use. The $Z$ Plant production facilities are being deactivated and new plutonium conversion facilities are presently in final design for installation in currently unused space in the Purex 202-A Building.

The uranium nitrate product solution is shipped to the Uranium Oxide Plant $\left(\mathrm{UO}_{3}\right)$ located in the 200 West Area, about five miles west of the Purex Plant, where it is converted to uranium trioxide powder. The Uranium Oxide Plant operation makes several thousand tons of uranium available for recycle and reuse in the overall reactor and fuel production cycle. This avoids discarding it as waste and also by recycling, helps reduce both the demand for new uranium and the related economic and environmental impacts of the uranium exploration, mining and milling operations. 
The neptunium wi11 be recovered and, depending on program requirements, will be stored onsite or shipped to another DOE site for use in other programs.

Throughout the history of the Hanford Reservation, environmental measurements and comprehensive evaluation programs (treated in detail in ERDA-1538) in radiation biology, ecology, hydrology and meteorology, have been maintained and have measured the impact of these operations on the environment.

Anticipated benefits of Purex Plant operation are: (1) the avai1ability of plutonium for defense and research uses, which include the entire spectrum of life sciences that study and evaluate the significance of plutonium in man's environment; and (2) the use of plutonium to develop technology for reactor operations and for use in reactor development programs. The defense uses contribute to maintaining the security of the United States. The operation of Purex Plant also permits onsite processing of $\mathrm{N}$ Reactor-irradiated fuel.

The Purex Plant is basically a large concrete structure designed for chemical processing by remotely operated and instrumented equipment. Thick walls and remote operation provide radiation protection for employees, and the totally enclosed process is isolated from the environment. Effluents are monitored and treated so that routine releases to the biosphere will not endanger the public or the environment. Although the Uranium 0xide Plant is a concrete structure, remote equipment operation is. not needed since radiation is not a problem. Effluents released meet the applicable regulations for environmental safety.

The fuels reprocessing operations are done under appropriate safeguards for special nuclear material (SNM). These safeguards are designed to prevent unauthorized access to or removal of SNM, to detect unauthorized entry or material moves, and to protect people and SNM from hostile action. 


\section{I.2 ENVIRONMENTAL EFFECTS}

\section{I.2.1 Routine Operations}

The data and calculations indicate that there will be no significant adverse environmental impact from the resumption of full-scale operations of the Purex and Uranium Oxide Plants.

The Purex Plant contributes little to offsite radiation doses; however, both the maximum individual and population whole body 50-year dose commitments calculated from the 1972 data used in ERDA-1538, are higher than those estimated in this assessment for future operational perfods. The actual decreases are expected to be from $5 \times 10^{-3}$ mrem for the maximum individual and $9 \times 10^{-1}$ man-rem population 50 -year dose commitments in 1972, to less than $2 \times 10^{-3}$ mrem per year and $2 \times 10^{-1}$ man-rem per year, respectively, in the 1983 to 1994 period. These calculated future radiation doses are lower than those in 1972 due to effluent reduction programs and Purex process improvements that have been made and which are continuing. Also, both the maximum and the average annual fuel reprocessing rates will be lower than in 1972, and the Purex Plant will be operated sequentially with the Uranium Uxide Plant and the Wasto Processing Plant (B Plant). The Uranium 0xide Plant does not contribute measurably to offsite radiation doses.

At the Hanford Reservation boundary, all radionuclide concentrations resulting from Purex Plant effluents will be well below the values of Depártment of Energy Manual Chapter 0524 Appendix, Annex A, Table II for uncontrolled areas. ${ }^{*}$ With the exception of tritiun $\left({ }^{7} H\right)$ dind the notle gases (principally $8{ }^{5} \mathrm{Kr}$ ), the radionuclides released in the gaseous effluents are expected to meet Table I values of the Manual Chapter at the point of discharge from the plant, and in most cases will meet the even lower concentration values of Table II. In addition, the concentrations

\footnotetext{
*Standard for Radiation Protection, U.S. Department of Energy Manual Chapter 0524, March 30, 1977.
} 
of radionuclides (except tritium) in liquid effluents, averaged over any continuous 12-month period as specified by DOEM 0524 Appendix, Section C.2, are also expected to meet Table II values at the point of discharge from the plant.

All significant pathways are evaluated. This includes submersion in the airborne effluent plumes, consumption of drinking water and foodstuffs irrigated with Columbia River water, ingestion of radioactive iodine through the cow-to-milk pathway, consumption of fish, and other less significant pathways.

A summary of research and surveillance programs designed to assess the possible changes in the terrestrial and aquatic environments on or near the Hanford Reservation is presented in Section II.1.2 of ERDA-1538.

The nonradiological discharges to the environment of principal interest are chemicals, sewage and solid waste. These discharges will not lead to any significant adverse effects on the environment.

\section{I.2.2 Effects of Postulated Accidents}

A range of credible accidents was analyzed whose consequences could vary from low severity to high severity. Among those analyzed for the Purex Plant are dissolving improperly cooled (unaged) reactor fuel, a solvent fire, and a nuclear criticality accident. A large spill of uranium oxide was postulated and analyzed for the Uranium Oxide Plant. The accidents analyzed also include the collision of a cask car (delivering irradiated fuel to the Purex Plant) with a fossil fuel transport truck followed by a fire and the burning of some of the uranium. Of those studied, this would be the accident with the most severe offsite radiation exposure impacts. As a result, the maximum individual would receive thyroid and total external body dose (50-year commitment) of 0.1 and 0.0005 rem, respectively. This same postulated accident would also contribute to the largest calculated maximum offsite population thyroid and bone dose of 40 and 1,000 man-rem, respectively (50-year dose commitment). 
The most severe offsite radiation exposure effects resulting from a postulated accident within the Purex Plant would be the dissolving of inadequately aged fuel. In this case, the calculated maximum for the population 50-year dose commitment to thyroid and bone would be 7.7 and 0.16 man-rem, respectively.

The probability of natural catastrophes during the contemplated operating period and the resultant release of radionuclides is considered to be extremely low and to represent dn acceptable risk. 


\section{DESCRIPTION OF SITE, PROGRAM AND FACILITIES}

\section{1 CHARACTERIZATION OF EXISTING ENVIRONMENT* \\ II.1.1 Hanford Reservation}

In early 1943, the U.S. Army Corps of Engineers selected the Hanford site as the location for reactor and chemical separation facilities for the production and purification of plutonium for possible use in nuclear weapons (Manhattan Project). The Hanford Reservation now occupies about 570 square miles of the southeastern part of the state of Washington (Figure II.1). A total of eight graphite-moderated reactors using the Columbia River water for once-through cooling, and a new type of dual-purpose reactor ( $N$ Reactor) using recirculating water coolant, were eventually built along the Columbia River.

Currently, $\mathrm{N}$ Reactor is the only production reactor at Hanford in operation. During plutonium production, the byproduct steam is being used for electricity generation at the adjacent Hanford Generating Plant (HGP), which is owned and operated by WPPSS. The $N$ Reactor facility is located along the Columbia River in the $100 \mathrm{~N}$ Area.

The reactor fuel reprocessing and waste management facilities are located on a plateau about seven miles south of $\mathrm{N}$ Reactor in the 200 Areas (Figure II.2). Five chemical separations plants were originally built; of these only the Purex Plant remains in service for fuel reprocessing. One, B Plant in the 200 East Area, has been converted to waste processing, and a portion of $U$ Plant in the 200 West Area has been converted to the Uranium Oxide Plant.

The reactor Fuels Production Facilities are located in the 300 Area just north of Richland, along with extensive research and development facilities.

\footnotetext{
*Detailed discussions and data covering all aspects of the Hanford regional environment are presented in ERDA-1538.
} 


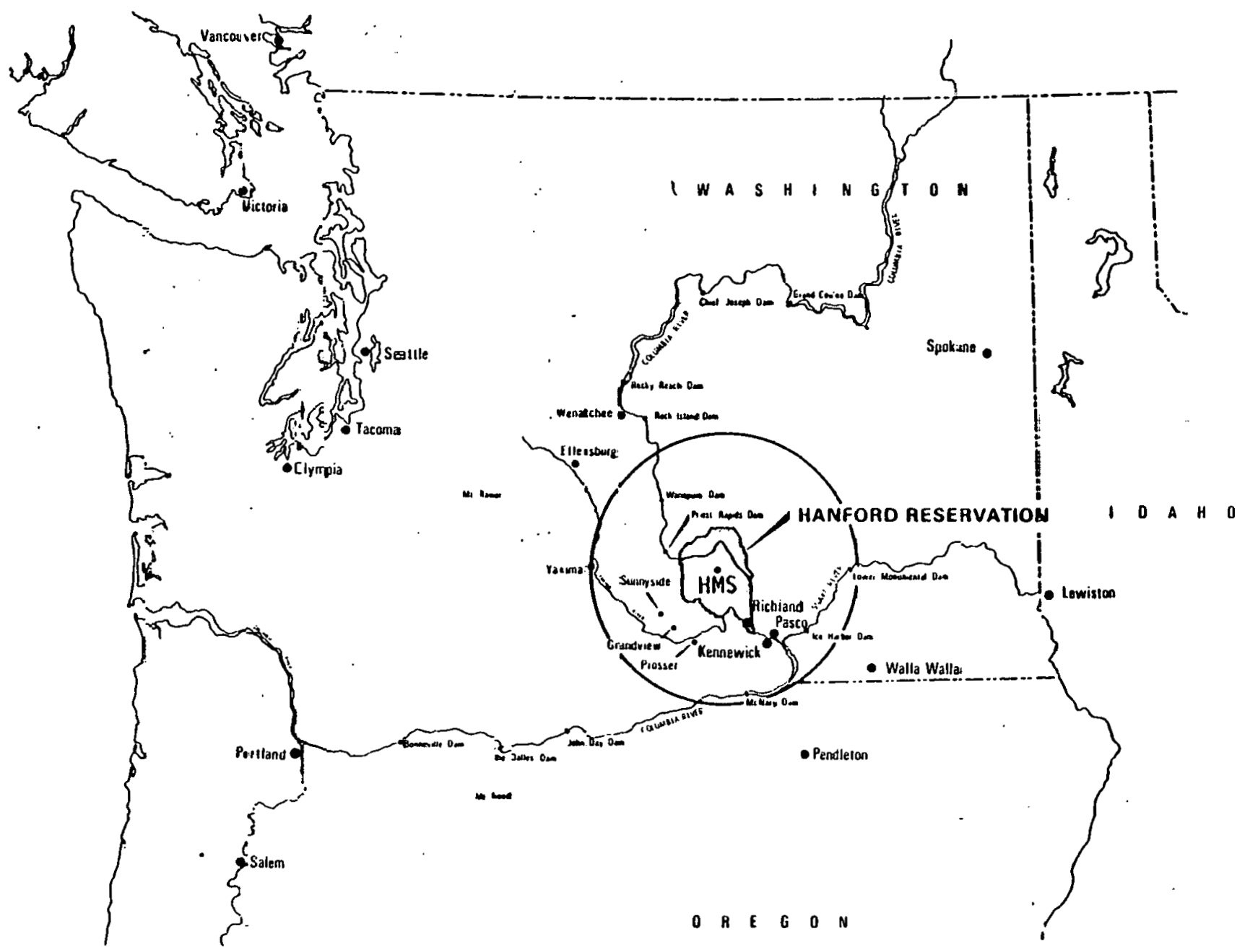

FIGURE II.]

LOCATION OF DOE HANFORD RESERVATION SHOWING 50-MILE RADIUS FPOOM HANFORD METEOROLOGICAL STATION (HMS) 


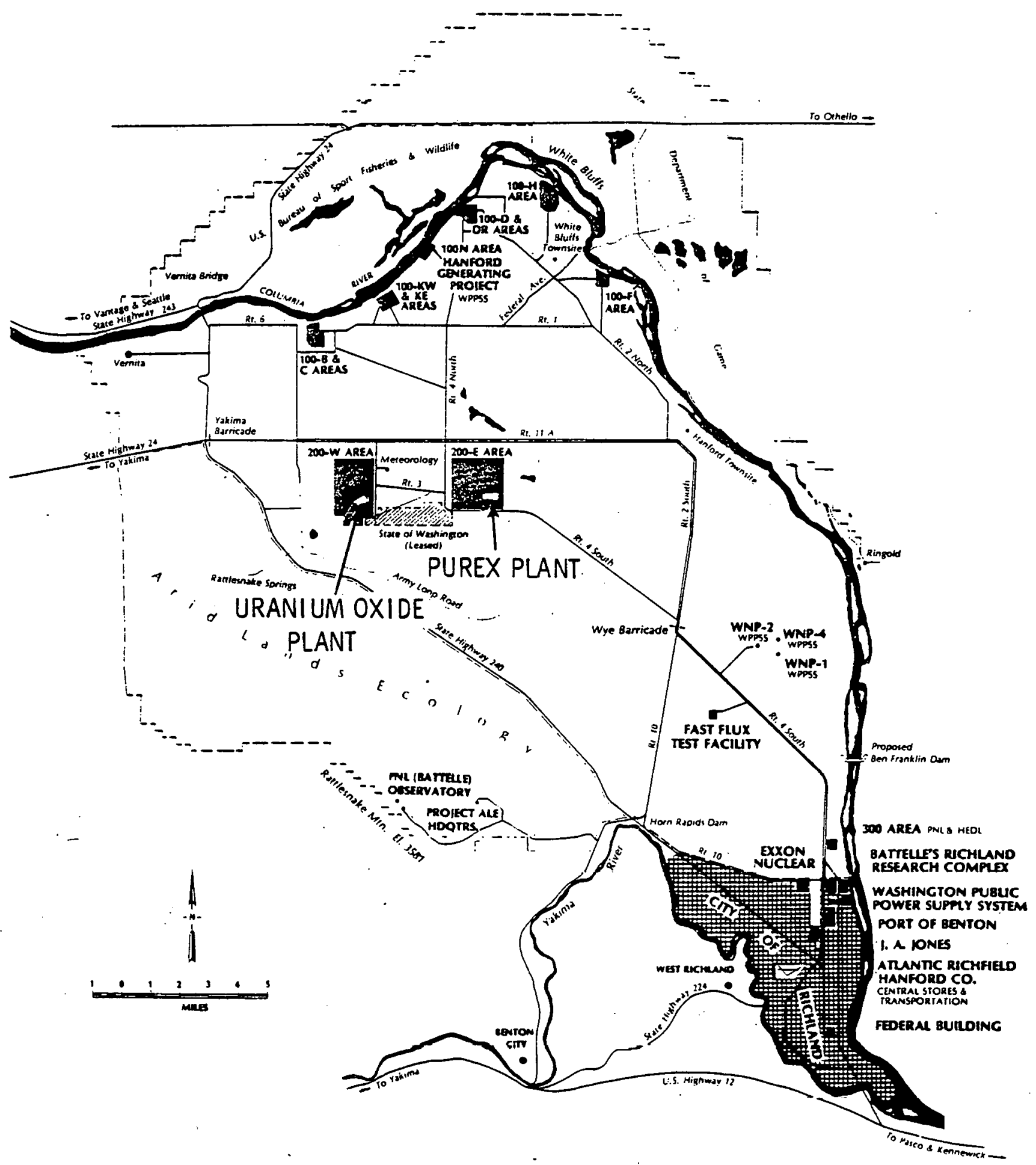

FIGURE II.2

MAP OF HANFORD RESERVATION 


\section{II.1.2 Demography and Land Use}

The population living within a 50-mile radius of the Hanford 200 Areas, centered on the Hanford Meteorological Station (HMS), is approximately 250,000 , * with the principal concentration of about 65,000 in the Richland, Kennewick, Pasco, Tri-Cities area 25 to 35 miles southeast of the HMS. Land uses in the surrounding area include urban, industrial, and irrigated and dry-land farming. Of the irrigated crops, alfalfa hay uses 30 percent of the total area, wheat 15 percent, and sugar beets about 8 percent. Water removal rights, other than Hanford's, amount to about 200,000 acre-feet per year within 50 miles of the $N$ Reactor, from an annual average river flow of about 120,000 cubic feet per second (cfs) or about 87 million acre-feet per year.

\section{II. i.3 Historical and Archaeological Sites}

Three sites listed in the National Register of Historic Places are within 50 miles of the Hanford Reservation. They are: (1) Marmes Rockshelter, (2) 0lmstead Place State Park, and (3) Whitman Mission National Historic Site. The remains of many Indian campsites and fishing grounds are found along the Columbia River within the Hanford Reservation boundary. Applications for listing 12 of these archaeological sites on the Hanford Reservation have been submitted to the National Register of Historic Places. There are no items of archaeological or historical interest in the 200 Areas.

\section{II.1.4 Hydrology}

The surface water and grnundwater hydrolony of the Hanford area is described in Section II.3.8 and Appendix II.3-D of ERDA-1538. A description of Columbia River flow, stage, temperature and water quality characteristics is included in those sections. A system of test wells

ॠThis total is predicted to rise to approximately 273,000 by 1990 . 
is in use throughout the Reservation for long-term monitoring of groundwater in both the confined and the unconfined aquifers. A map of these wells is presented in Appendix II.3-D of ERDA-1538. Recent studies and maps of the Hanford Reservation water table are also shown and discussed in ERDA-1538.

The U.S. Army Corps of Engineers has postulated a probable maximum flood (PMF) for the Columbia River basin, based on a combination of most severe climatic conditions. Contributing factors of winter snow accumulations, spring melting and runoff, and season rainstorms were maximized for the study. The projected flow for the PMF is 1.44 million cfs at the Hanford site compared with the long-term annual average flow of $120,000 \mathrm{cfs}$. The 200 Areas fuel reprocessing facilities, located at about 700 feet above mean sea level (MSL), are situated from 200 to 250 feet above the highest water elevation of the PMF.

\section{II.1.5 Ecology}

The Hanford Reservation is characterized as a shrub-steppe area with sparse vegetation dominated by sagebrush, bitterbrush and cheatgrass. There are no significant tree growth areas other than a few willows near surface waters.

The anadromous salmon and the steelhead trout are the fish of economic importance in the Culumbia River. About 9,500 fall Chinook salmon spawn in the Hanford reach of the river. The mule deer is the only big game mammal, while the cottontail rabbit is the most abundant sma11. game mammal on the Reservation. Sma11 mammals are abundant, particularly the Great Basin pocket mouse. The chukar partridge is the most important gamebird. Hunting is not permitted on the Reservation.

\section{II.1.6. Meteorology}

The climate has been recorded since 1912, and is characterized as mild and dry with occasional periods of high wind. The average maximum 
temperature of $91.8^{\circ} \mathrm{F}$ occurs in July; the average minimum temperature of $22.1^{\circ} \mathrm{F}$ occurs in January. The average annual precipitation is 6.25 inches. and occurs mainly in November through January. Tornadoes are rare in this region and tend to be smal1, with little damage when they do occur. In 30 years of observation, a single small tornado has been observed on the Reservation; this resulted in no damage. The maximum recorded straight wind velocity was 80 miles per hour from the southwest at the 50 -foot level of the HMS tower.

Charts ("wind roses") are included in ER.QA=1538 for wind measure= ments at the HMS located near the center of the Hanford Reservation approximately four miles west of Purex Plant and two miles northeast of the Uranium Oxide Plant. These show prevalent wind patterns in terms of joint wind speeds, directions and frequencies.

\section{II.1.7 Geology and Seismicity}

Eastern Washington is dominated by the Columbia Basin geologic province, which encompasses about 50,000 square miles. It is underlain by the vast field of lava flows of the Columbia River basalt group. Late in the Pleistocene epoch, large floods scoured and carved the Ringold formation surface beneath the Hanford Reservation. These floods, of about 18,000 to 12,000 years ago, deposited the sediments now found on the site.

The Hanford Reservation lies in a region of low to moderate selsmicity situated between the active seismic zones of western Washington and western Montana. It lies in Zone 2 of the seismic probability map (1949) of the Uniform. Building Code and the seismic risk map of the U.S. Coast and Geodetic Survey (1969), which implies the potential for moderate damage from earthquakes. The Puget Sound and northern Rocky Mountain areas are in Zone 3 , which implies the risk of considerable damage. 
The Hanford Reservation area has not experienced a damaging earthquake in historic time. The strongest earthquakes have not exceeded a value of four on the Modified Mercalli Intensity Scale (MM-IV), although intensities as high as MM-VII have been noted in the surrounding region. Two earthquakes, each of intensity MM-IV to MM-V, have occurred approximately 20 miles north of the 200 East Area where the Purex Plant is located (Figure II.2), both near the town of Corfu. In 1893, the Umatilla, Oregon area* experienced an MM-VII quake and in 1936, the Walla Walla, Washington area also had an MM-VII quake. In 1934, at Ellensburg, Washington, and in 1956 near 0thel10, Washington, ** short series of numerous brief shocks occurred. The strongest shocks had MM-VI maximum intensity, but they were highly localized. Ground motions in the Hanford area from the Umatilla and Corfu quakes were not greater than three percent of gravity acceleration $(0.03 \mathrm{~g})$, considerably less than those associated with Zone 2 designation.

Active fault zones in Washington, as deduced from earthquake activity, are shown in Figure II.3. However, no clear relationship of epicenters to specific surface faults or structures is yet recognized in eastern Washington.

The site considered to be the largest potential earthquake generator near Hanford is the postulated Rattlesnake-Wallula fault at the southeast end of the Rattlesnake Hills; there are no recognized faults closer to the site. The most severe probable earthquake for Hanford, postulated to originate at this site with an epicentral distance about 10 . to 12 miles from the Purex and Uranium Oxide Plants, is estimated to result in the maximum horizontal ground acceleration of $0.25 \mathrm{~g}$ and vertical acceleration of $0.17 \mathrm{~g}$; these values are greater than any measured or estimated for the Hanford Reservation that have been caused by any known quake of historic times. A quake this large, as noted in ERDA-1538, has

\footnotetext{
*Approximately 45 miles due south of the 200 East Area. **Approximately 25 miles northeast of the 200 East Area.
} 
an occurrence associated with an unlimited time span per occurrence, whereas the probability of an acceleration of $0.20 \mathrm{~g}$ would be once every 16,700 years, of $0.15 \mathrm{~g}$ once every 4,000 years, $0.10 \mathrm{~g}$ once every 1,850 years, and $0.05 \mathrm{~g}$ once every 840 years.

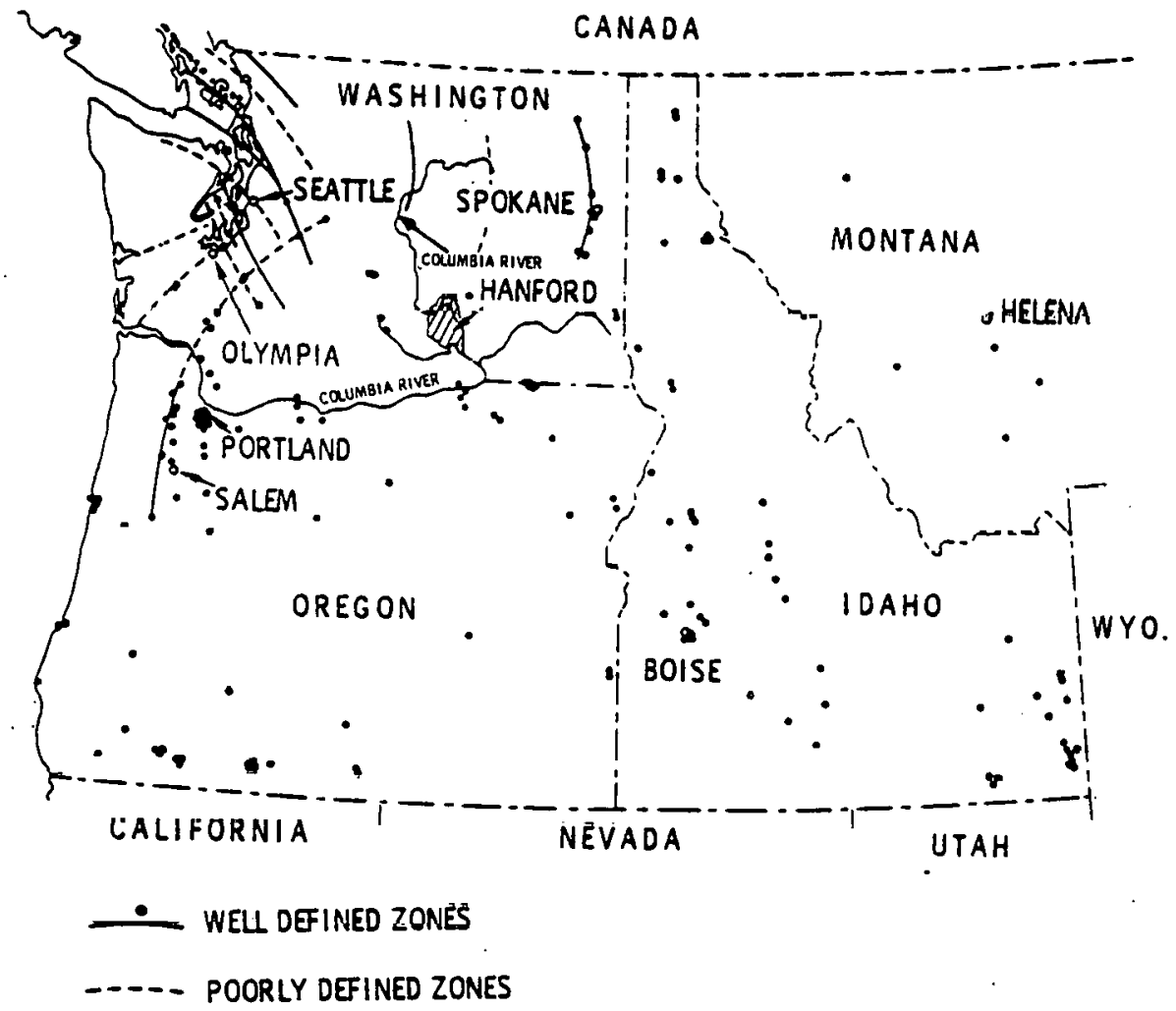

FIGURE II.3

EARTHQUAKE ZONES OF WASHINGTON

\section{II.2 DESCRIPTION OF PROGRAM}

\section{II.2.1 Operational Relationships}

The $\mathrm{N}$ Reactor is currently operating to produce plutonium for DOE research and for national defense commitments. During this operation the reactor heat produces steam that is provided to WPPSS for the production of electricity. Fuels production systems and facilities located in the 300 Area manufacture the fuel for the reactor operations. This 
fuel is irradiated to produce the quality of plutonium the current programs require. Following irradiation, the fuel is ejected into large water-filled basins where it remains in storage to await reprocessing by the Purex and Uranium 0xide production facilities located in the 200 Areas.

The operation of these production facilities in the 200 Areas involves the transfer of the irradiated fuel from $N$ Reactor storage to the Purex Plant, and the chemical reprocessing of the fuel elements to recover the plutonium, uranium and neptunium. The operation of the Purex Plant and the continued operation of $\mathrm{N}$ Reactor will affect the waste management operations at Hanford. The impact on these operations has been evaluated and is discussed in Sections III and $V$ of ERDA-1538.

Exact production plans and schedules have not been firmly established for future $N$ Reactor operations. Schedules for the Purex Plant will be determined by $N$ Reactor programs and will be set to provide the best balance among the factors of overall cost effectiveness, the maintenance of a fully trained work force, the effective operation of uranium oxide and waste management facilities, and the elimination of extended interim plant shutdowns.

If the reactor is operated in the 6 percent $240 \mathrm{Pu}$ production mode during the period FY 1983 to 1990 (a recent study basis), approximately 7,100 metric tons of uranium (MTU) fuels, total, will be discharged for reprocessing. This includes the current backlog. If the reactor remains on 12 percent $240 \mathrm{Pu}$ production mode, the total will be about 5,200 MTU.

For the production of plutonium containing 6 percent $240 \mathrm{Pu}$, annual reactor discharge is about 700 to 750 MrU containing approximately 950 to 1,000 grams of plutonium per metric ton. For the production of plutonium containing 12 percent $240 \mathrm{Pu}$, annual discharge is about 300 to 325 MTU containing approximately 1,900 to 2,000 grams of plutonium per metric ton. Some plutonfum with about 9 percent 2" $0 \mathrm{Pu}$ has been 
produced in $\mathrm{N}$ reactor. Approximately 335 MTU containing about 460 to 470 kilograms of plutonium of this composition is in storage and will be reprocessed during the scheduled campaigns.

Because of the uncertainties in schedules and future programs, this report has been based on the annual impacts of an assumed maximum Purex Plant production rate of 1,000 MTU per year rather than on the total tonnage and time span. Since it is obvious that the maximum rate wil1 not be reached in most of the operating years, 1,000 MTU per year represents the upper limit of impact that will be incurred annualiy.

When the Purex Plant is restarted, it will be operated sequentially with the Waste Processing Plant ( $B$ Plant) and the Uranium 0xide Plant until all current and future irradiated $N$ Reactor fuels have been reprocessed. In the sequential mode, the Purex Plant will be operated on a "campaign" basis, with two to four campaigns per year, reprocessing a total of from 500 MTU per year to a maximum of about 1,000 MTU per year.

Uranium recovered as uranyl nitrate solution from the Purex Plant will be shipped by tank truck to the Uranium Oxide Plant in the 200 West Area.

The Uranium 0xide Plant will be operated in one or two short campaigns each year to convert the uranyl nitrate to uranium oxide $\left(\mathrm{UO}_{3}\right)$. The $\mathrm{UO}_{3}$ will be packaged for shipment to either the gaseous diffusion plant in Paducah, Kentucky, to be reenriched in the $235 \mathrm{U}$ isotope, or to the National. Lead Company in Fernald, Ohio, for conversion to metal. Neptunium-237 recovered as a nitrate solution in the Purex Plant will be purified, and as governed by program requirements, will either be stored onsite or transported in Department of Transportation-approved containers to the Savannah River Plant, Aiken, South Carolina, to be used in the production of $238 \mathrm{pu}$. 
The Purex Plant plutonium nitrate product solution will be converted into plutonium oxide powder in conversion facilities presently in design for installation in existing unused space in the Purex Plant $\mathrm{PR}$ Room, in $\mathrm{M}$ Cell and $\mathrm{N}$ Cell. The resultant final plutonium oxide product will be shipped directly to customers or placed in storage, as appropriate. This will permit deactivation of the corresponding oxide processing lines in $\mathrm{Z}$ Plant.

The solvent extraction cycle current acid waste (CAW) from the Purex Plant operations will be processed in B Plant where most of the cesium and strontium fission products will be removed from the waste. The recovered cesium and strontium fractions will be encapsulated and stored in the Waste Encapsulation and Storage Facility (WESF). See ERDA-1538, Section II.1.1.2.2.1 for detailed discussion of B Plant waste separation and encapsulation. The encapsulation now in progress will be continued until current strontium and cesium inventories have been processed; WESF will then go on standby until new inventories are accumulated from the reprocessing of $\mathrm{N}$ Reactor fuels.

The high-heat, high-level radioactive aqueous waste stream from B Plant operations will be made alkaline and stored in double-wall underground tanks for a period of up to five years after discharge from the reactor. This storage period will allow decay of most of the remaining short-lived and intermediate-lived radionuclides with halflives of up to about one year. The alkaline waste wi. 11 then be converted to damp, semi-solid salt and residual liquid waste in the new 242-A Vacuum Evaporator-Crystallizer.

Each metric ton of reactor fuel reprocessed through the Purex Plant will represent from 220 to 250 gallons of CAW to be processed through B Plant. This volume, in turn, will represent from 370 to 420 gallons 
of alkaline waste for storage, equivalent to 60-70 gallons of salt cake and 45-50 gallons of residual liquid. In addition, each MTU reprocessed will also result in 1,300 to 1,350 gallons of low-heat waste from the Purex Plant (coating waste, organic wash waste and laboratory waste) to be evaporated in the 242-A Vacuum EvaporatorCrystallizer to produce about 50-55 gallons of salt cake and 35-40 gallons of residual liquid waste.

\section{II.2.2 Anticipated Bencfits}

\section{I1.2.2.1 Purex Plant Operation}

The operation of Purex facilities will permit onsite reprocessing of $\mathrm{N}$ Reactor-irradiated fuel thus reducing need and cost for on-going storage of $\mathrm{N}$ Reactor spent fuel at Hanford. By reactivating the Purex$\mathrm{UO}_{3}$ facilities in 1983, the need for additional costly fuel storage facilities will be eliminated.

Plutonium now in the stored irradiated fuels will be, made available for national defense needs, for reactor safety programs, and for nuclear research and development work.

The Purex Plant will be operated sequentially with B Plant and the Uranium Oxide Plant, thus representing the most cost-effective usc of the same pool of experienced manpower to operate all three facilities.

It is anticipated that benefits will be derived frum avoiding the need to send the fuels offsite. from avniding the related costs and offsite population and environmental exposures, and from using locally available skilled and nonskilled labor forces. 


\section{II.2.2.2 Uranium Oxide Plant Operation}

Operation of the Uranium Oxide Plant provides the benefit of making several thousand tons of uranium available for recycle and reuse in the overall reactor and production fuel cycle. This avoids the undesirable alternative of storing the uranium as a solution (which would require building new tanks for the necessary storage capacity) and the equality undesirable alternative of discarding it as waste. Recycle also helps reduce both the demand for virgin uranium and the related economic and environmental impacts of the uranium exploration, mining and milling operations. Uranium Oxide Plant operations also help to achieve the most cost-effective use of the 200 Areas' work force since the plant is operated by members of the Purex Plant work crews in al ternating sequence with the Purex Plant.

\section{II.2.3. Safeguards}

Safeguards and special precautions apply not only to individual facilities but also to the Hanford operations in general. Each contractor in coordination with DOE is responsible for industrial security and safeguards.

The safeguarding of special nuclear material (SNM) consists of five basic elements:

- the accountability system. which maintains records of SNM additions and withdrawals, and which ensures continuous knowledge of amounts of SNM in process and inventory;

- the prevention of unauthorized access to and/or removal of SNM;

- the detection of unauthorized personnel entry and/or removal of Sill:;

- the timely and effective response to threats or intrusions in order to prevent removal and/or provide recovery of SiM;

- the protection of people, facilities and SNM against overt planned or impulsive (hostile) action. 
The Purex Plant, which handles and temporarily stores SNM, is a protected area appropriately fenced, guarded and locked. It is located inside the 200 East Area, which is a limited access area also appropriately fenced, guarded and locked. However, because the Purex Plant, which has not operated since 1972, does not now fully conform to the safeguards and security requirements of DOE Manual Chapters 2401 and 2405, the necessary upgrading is in progress. The improvements will include:

- a new bullet-resistant guardhouse with expanded communications, emergency power, and computerized alarm monitoring and assessment capabilities;

- strategically placed SNM detectors for both people and vehicular traffic;

- devices for detecting metal and explosives;

- personnel entry and exit radiation monitors

- closed-circuit television cameras in conjunction with SNM detectors and intrusion alarms;

- special door locks at key locations;

- intrusion detection systems in appropriate locations;

- security grills on exhaust ducts and steel plate door reinforcements as needed.

New cables, alarms, communications equipment, emergency power, and built-in system function check capability will be included as integral parts of the total upgrading project.

Entry to the 200 Areas and to each of the individual protected areas through gates and manned stations is controlled by armed security guards and is limited to those people who are on official business and carry the proper identification and authorization. The 200 East Area is located near the center of the Hanford Reservation, access to the central portion of which, is also restricted by armed security guards and 1 imited to those people who are on official business and carry the proper identification and authorization. 
All personnel and vehicles entering and leaving the Reservation, the 200 Areas and the protected areas, are subject to search. Business visitors are admitted only if they carry proper security clearance and identification and are accompanied by suitable official escort. Records are kept of all visitors.

Within all plants and facilities, access to SNM that has been adequately separated from other radioactive elements is under the direct control of a responsible assigned individual and is strictly limited to duly authorized persons. Rigorous administrative procedures, records and redundant control routines, are designed to reduce the probability of accidental removal and deliberate diversion of SNM to the absolute minimum.

Electronic monitoring and visual inspection of people entering and leaving the protected areas, and of the possessions and vehicles of such persons, are done to detect and prevent potential deliberate theft and accidental diversion of SNM, and to ensure that weapons or other prohibited articles are not brought into these areas.

Instruments and alarms of various types are strategically located to detect and indicate deliberate unauthorized attempts to intrude in vaults, restricted areas or facilities, or to gain access to SiM. Random checks of SNM storage locations are made on a 24-hour-per-day basis by roving security guards using appropriate surveillance techniques.

Armed guards protect against overt hostile action, physical violence and forced entry. The guard force is trained and equipped for immediate response to prevent or contain such a situation and to reestablish control following the situation without loss or compromise of SNM.

Security guards also provide escort and protection during the movement of SNM outside the fenced facilities in the course of transfer of these materials from one location to another on the Hanford Reservation. 


\section{3 DESCRIPTION OF FACILITIES}

\section{II.3.1 Purex Plant Facilities}

\section{II.3.1.1 General Description}

The Purex Plant, located in the southeast corner of the 200 East Area (shown in Figure II.2), is a complex of several buildings and supporting facilities. A detailed map of the 200 East Area is given in Figure II.4.

The 202-A Building, in which the fuels are reprocessed, is shown in Figure II.5. The view is of the north face showing the annex (offices, laboratories, etc.) and main entrance.

The structure is of reinforced concrete and is about 1,000 feet long, 120 feet wide at its maximum, and 100 feet high with about 40 feet of this height below grade. It consists of three main structural components: (1) a thick-walled, concrete "canyon" in which the equipment for radioactive processing is contained in cells below grade; (2) a pipe, sample and storage gallery section; and (3) a. steel-and-transite annex that houses offices, process control rooms, laboratories and the building services. The basic features and arrangement are shown by vertical cross section and plan views in Figures II.6 and II.7, respectively. The portion of the canyon below grade is subdivided into a row of process equipment cells paralleled by a ventilation air tunnel and a pipe tunnel through which intercell solution transfers are made.

The air tunnel exhausts the ventilation air from the cells to the main ventilation filters and stack. Running nearly the full length of the canyon building above the cells and the pipe trench, is a craneway for three gantry-type maintenance cranes that are used to handle cell cover blocks, remotely remove and replace process cell equipment, and charge irradiated fuels into the dissolvers. 


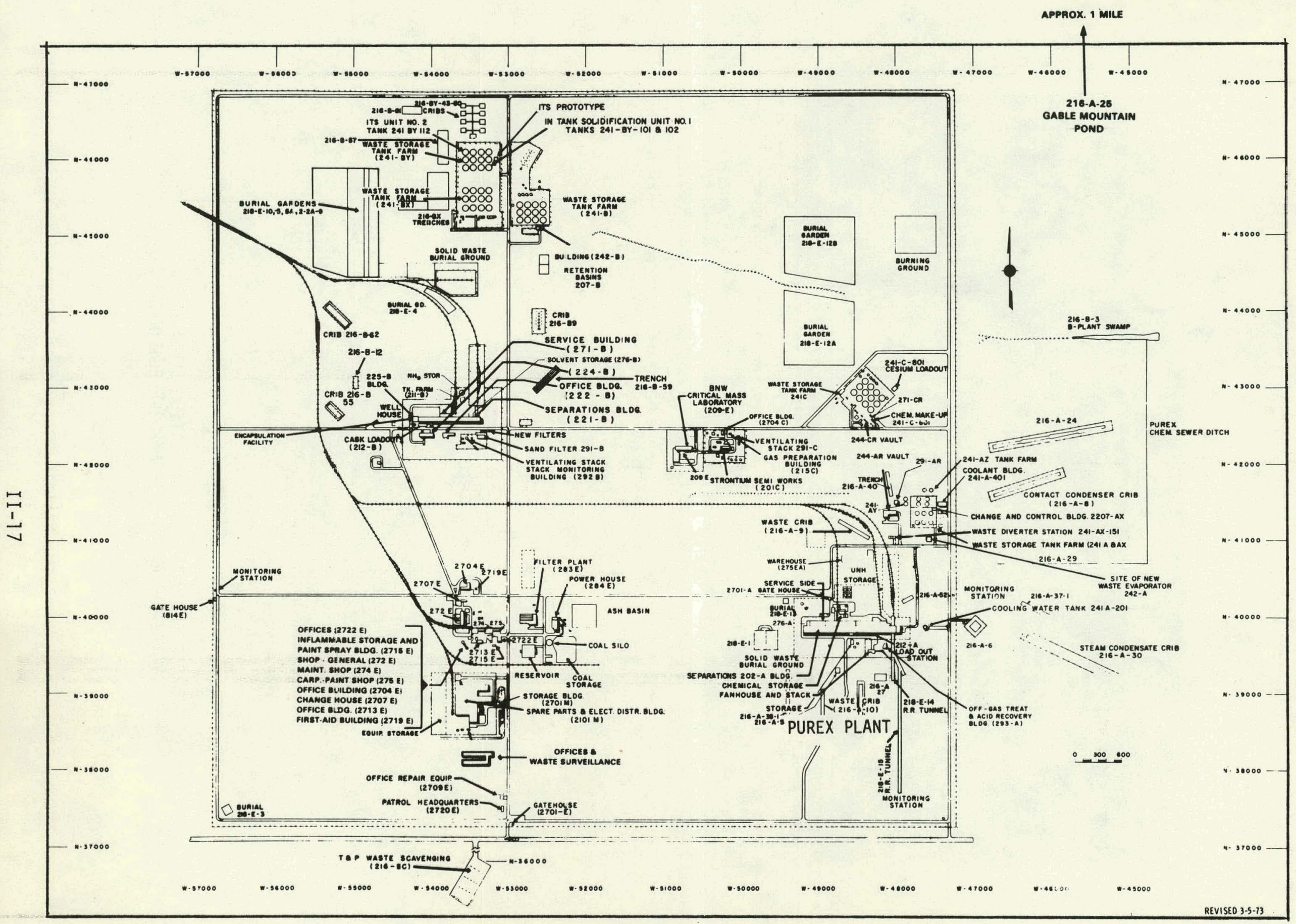




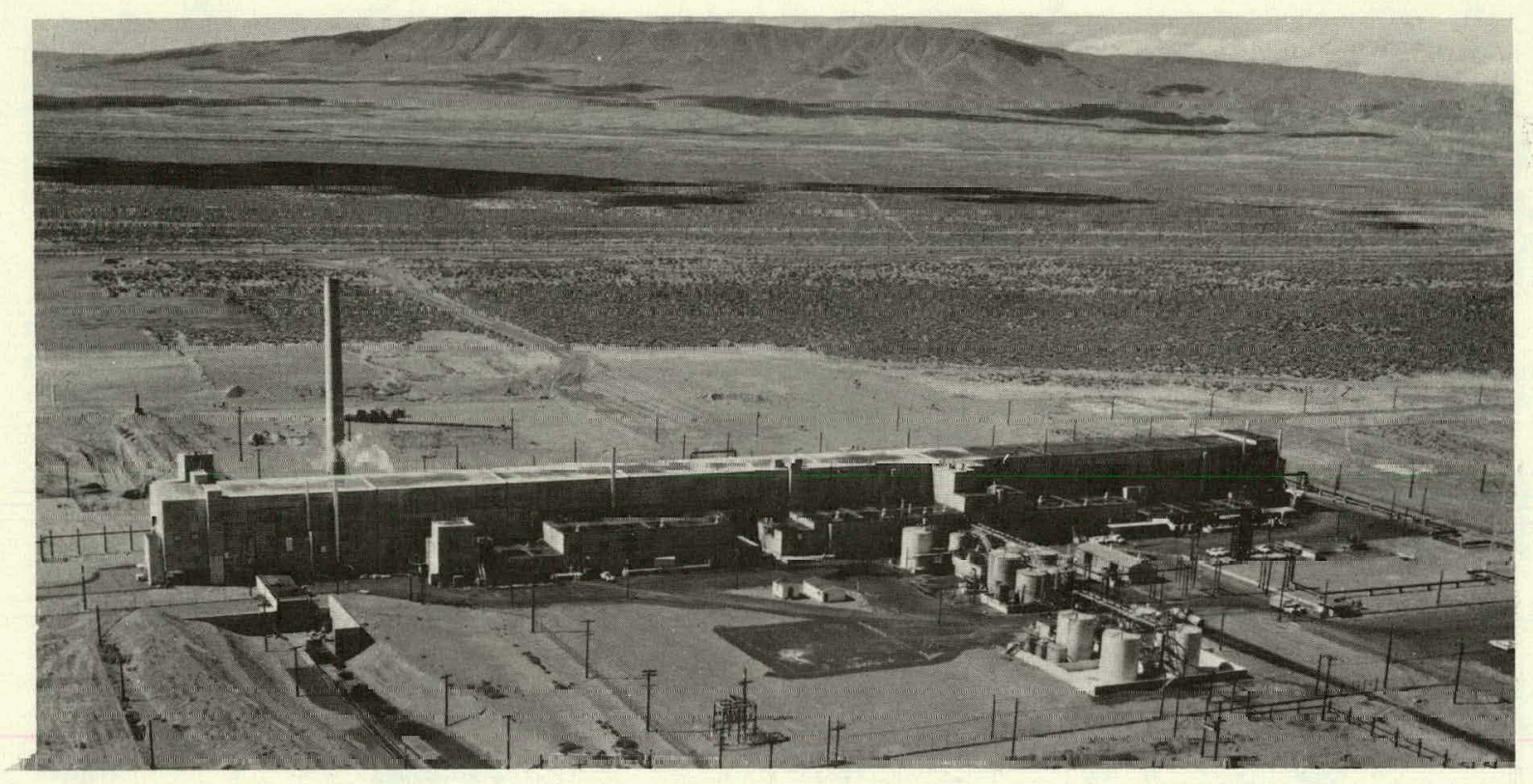

\section{FIGURE II. 5}

THE PUREX PLANT

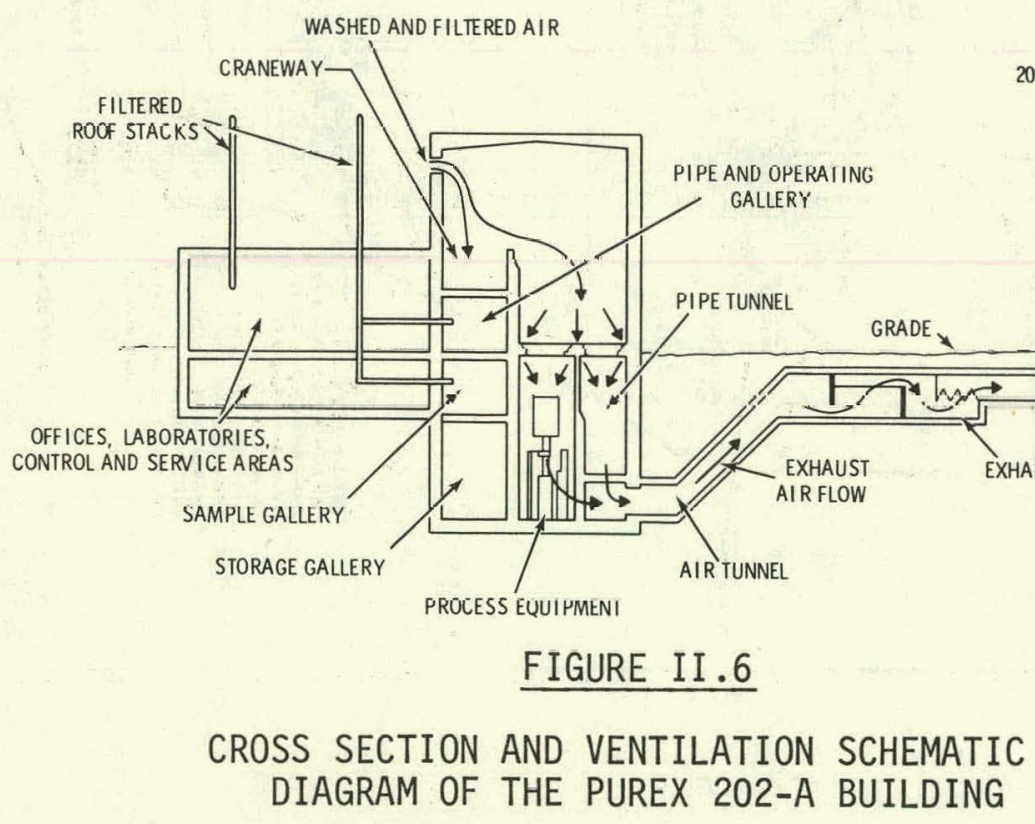




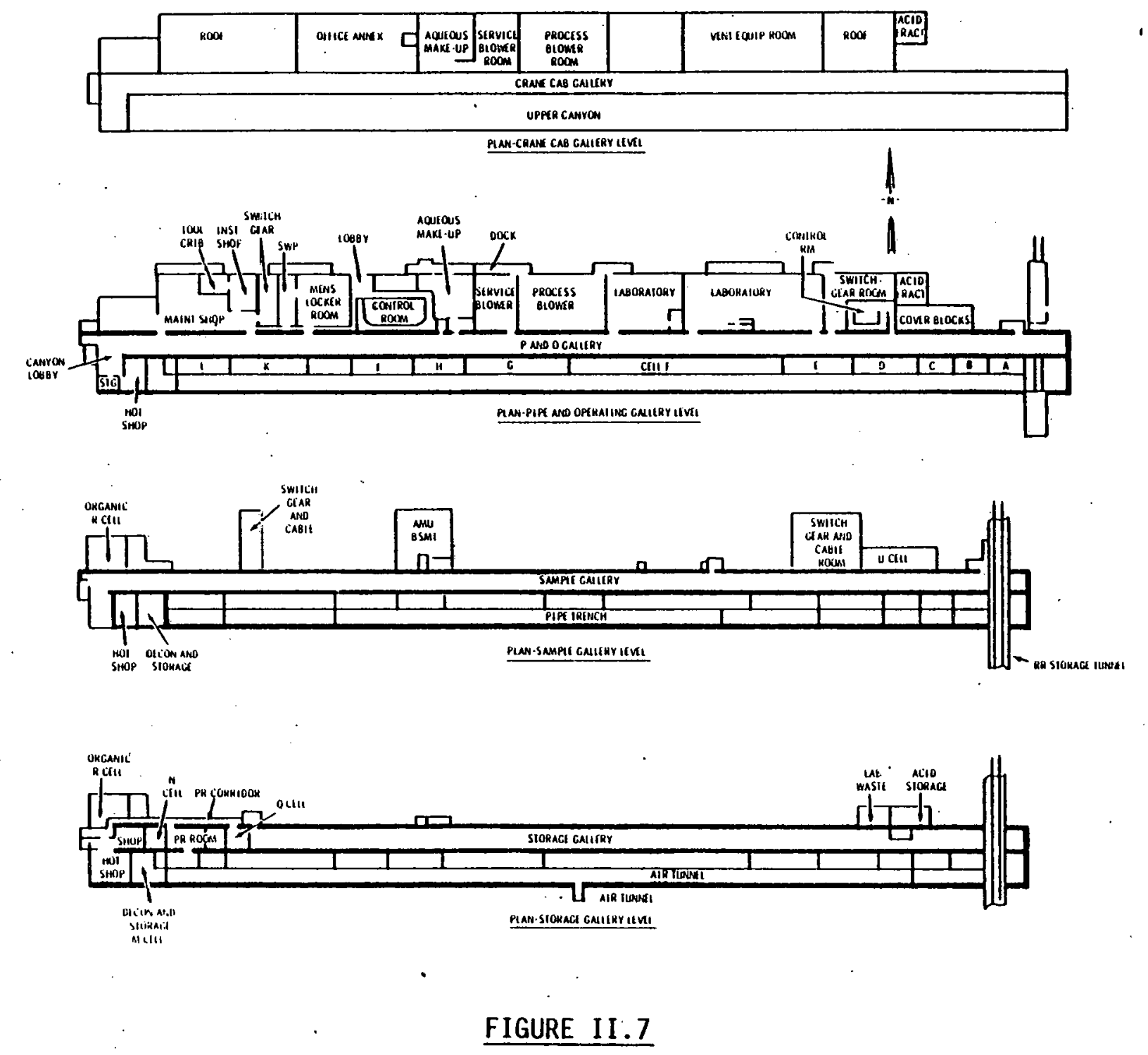

PLAN VIEWS OF THE PUREX 202-A BUILDING 
The galleries contain service piping to the cells, samplers for obtaining process samples, and electrical switchgear.

The service section next to the galleries consists of two separate annexes. The larger annex contains the maintenance shops, offices, lunchroom, locker room, radiation zone entry lobby, blower room, a switchgear room, compressor room, central control room and the aqueous makeup facility. The smaller annex contains the analytical laboratory, the head-end control room and a switchgear room. These general features are illustrated in Figure II.7.

The 202-A Building canyon contains a single row of 12 process cells 813 feet long overal1. The cells are 14 feet wide and 39.5 feet deep; lengths of the cells vary depending on function. At the east end (headend $L$ are a storage bas in for temporary storage of irradiated fuels, and the railroad tunnel, an integral part of the canyon, used for bringing in the irradiated fuels and for delivering and removing process equipment.

The first three cells, $A, B$ and $C$, are the cells in which fuels are declad chemically and dissolved. They are essentially identical in function and equipment; in addition to the dissolver, the cells contain ancillaries for processing off-gas from the dissolver. These ancillaries are a down-draft condenser, ammonia scrubber and absorber, steam and electric heaters, silver reactor and filter.

Cells $D, E$ and $F$ are used for preparation of the metal solution feed for the solvent extraction columns, for the recovery of nitric acid used in the process, and for treatment of the aqueous high-level waste from the fuel reprocessing steps.

In $G$ Ce11, all the used process organic solvent except that from the second uranium cycle, is treated to remove impurities and prepared for recycle and reuse. 
The solvent extraction processing steps are carried out in $\mathrm{H}, \mathrm{J}, \mathrm{K}$ and $L$ Cells, which contain the tanks, solvent extraction pulse columns, concentrators and auxiliaries needed in the continuous counter-current aqueous-organic stream flow operations.

Next to $L$ Ce11, at the west end of the canyon, there is a decontamination and semi-remote hot shop in $M$ Cell for repair and maintenance work on process equipment. A portion of this cell will be partitioned off for use in the new plutonium nitrate conversion facility (Section II.2.1.).

Four other cells, not included in the canyon proper but having specific functions in the overall process, are:

- $\underline{\mathrm{NCell}}$ - conversion of plutonium nitrate to plutonium dioxide (formerly used for plutonium product purification by ion exchange but no longer used for this purpose, having been replaced by the $L$ Cell third plutonium cycle);

- Q Cell - the neptunium recovery and purification facility located at storage gallery level in the west end next to the product removal room; $Q$ Cell includes a control room, a shielded hot cell, a maintenance room with shielded access glove boxes, a product loadout room, and an aqueous makeup area;

- $\underline{R}$ Cell - located at the west end on the north side of the 202-A Building; $R$ Cell houses the equipment used for chemical treatment of the used organic solvent from the second uranium cycle;

- U Cell - the acid storage vault located along the north wall of 202-A Building just east of the head-end control room; it is constructed below grade with concrete cover blocks one foot above grade forming the roof, and contains four tanks that are used to collect low-activity laboratory 
RHO-CD-742

waste and to store recovered nitric acid that is returned to the process.

Next to $U$ Cell is the 206-A Building that houses the vacuum acid fractionator. Recovered acid from the fractionator is stored in $U$ Cell.

The PR Room is located at the west end of the storage gallery adjacent to $L$ Cell. This room contains two plutonium sampler tanks shielded from the working area by concrete walls. Equipment within a transparent enclosure built on a stainless steel framework is operated by extension handles on the valves. A doorway from the PR Room provides access to $\mathrm{L} \mathrm{Cell}$ in case nonroutine contact maintenance of the third plutonium cycle equipment is required.

The 291-A Building is the main ventilation exhaust facility for the 202-A Building and consists of tunnels, two underground glass fiber filters in parallel (each consisting of two separate filters in series), and the 200-foot-tall stack through which canyon exhaust air is discharged to the atmosphere. A third main ventilation filter has recently been installed in parallel for use on a standby (backup) basis following resumption of plant operation.

The 293-A Building is a small reinforced concrete structure near the 291-A Exhaust Stack. It contains the 202-A Building dissolver offgas backup process equipment that removes most of the oxides of nitrogen for recovery as nitric acid before the off-gas is released through the stack to the environs.

The 294-A Building is a covered concrete cell below grade near the 293-A Building. It contains three glass fiber backup filters, one for each of the dissolver off-gas streams from the 202-A Building; they provide redundancy to the similar filters in each of the dissolver cells. These filters are upstream from the 293-A Building. 
In addition to the above facilities, there are two burial tunnels (actually one branched tunnel) extending southward from the 202-A Building, in which large pieces of failed process equipment are stored on abandoned railroad cars. These tunnels are earth-covered extensions of the rail spur on which reactor fuels are delivered to the plant for chemical reprocessing. The tunnels serve as intermediate storage for solid radioactive waste too radioactive and too bulky to remove from the canyon to the burial ground until significant radioactive decay of the fission products has occurred.

\section{II.3.1.2 Operational Programs}

The function of the Purex Plant is to separate, recover and purify three principal products (plutonium, neptunium and uranium) from irradiated nuclear reactor fuels.

The uranium product is produced as a nitrate solution which is converted to the oxide $\left(\mathrm{UO}_{3}\right)$ in the Uranium Oxide Plant and then shipped to another DOE site for reintroduction to the fuel cycle.

Up to the present, the final plutonium product from the Purex Plant has also been a nitrate solution. This has been transferred to Z Plant for conversion to either oxide or metal as the final Hanford product form. Currently, however, work is in progress to equip the Purex Plant with the capability to make plutonium oxide $\left(\mathrm{PuO}_{2}\right)$ as the final product.

The conversion will produce a solid stable product that will be sealed in containers for transfer to the customer or to interim storage in the 200 West Area. This processing will be done in new facilities installed in the idle $N$ Cell (Section II.3.1.1), the PR Room, and the adjacent $M$ Cell in the canyon (now used only occasionally for equipment maintenance and decontamination). 
Depending on DOE program requirements, the neptunium product will be shipped offsite (to Savannah River Plant) or will be stored onsite at Hanford.

The high-level radioactive waste is transferred to $B$ Plant for fission product separation and preparation for storage. (Refer to ERDA-1538 for a comprehensive discussion of the waste management program.) Process condensate discharged from the plant (normally only that from the final uranium cycle concentrator) is sent to an underground crib (covered trench). Steam condensates and the condensate from the ammonia scrubber waste concentrator are also discharged to cribs. Cooling water is discharged to a surface pond. Radioactive solid waste is disposed of onsite according to bulk and the amount and type of radioactive material present. Nonradioactive solid waste is buried in the central landfill disposal site near the center of the Hanford Keservation.

\section{II.3.1.3 Operational Systems}

A schematic flow diagram of the Purex process is given in Flgure II.8.

The $N$ Reactor fuel elements are metallic uranium clad in Zircaloy, a zirconium-tin alloy. There are two principal types of fuel elements, designated the Mark I-A and the Mark IV, to be reprocessed at the Purex Plant. They are basically the same design, but differ primarily in length (and therefore in weight per element) and degree of enrichment, that is, the initial concentration of $235 \mathrm{U}$. The design is that of a tube within a tube. There are differences also in cladding thicknesses and thus minor differences in the amount of uranium per unit of length.

The Mark I-A, called the "spike"; is 21 inches long and has a total uranium weight of 36.6 pounds. The outer tuhe has an initial enrichment of 1.25 percent $235 \mathrm{U}$, the inner tube is 0.95 percent ${ }^{235} \mathrm{U}$, and the 


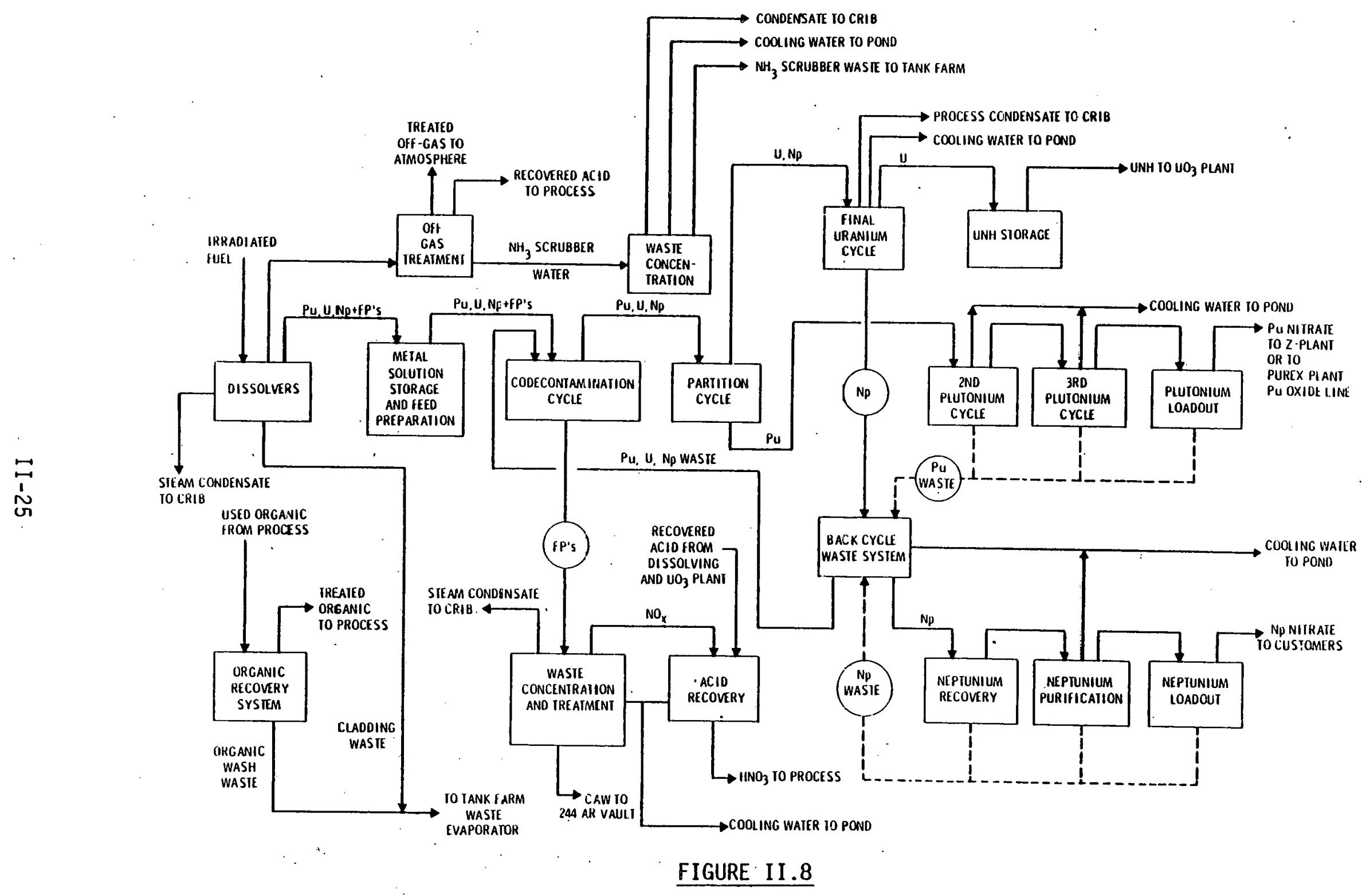

PUREX PROCESS SIMPLIFIED FLOW DIAGRAM 
initial average for the total element is 1.15 percent ${ }^{235} \mathrm{U}$. This type of element is used to obtain the desired reactivity pattern in the iv Reactor, and represents approximately 20 percent of the total reactor charge.

The Mark IV element, representing approximately 80 percent of the reactor core load, is 26 inches long and has a uranium weight of 51.7 pounds. Both the inner and outer tubes are enriched initially to 0.95 percent ${ }^{235} \mathrm{U}$.

The average concentrations of $235 \mathrm{U}$ in the Mark IV fuel after irradiation, range from 0.83 percent when the reactor is operated to produce plutonium containing 6 percent ${ }^{240} \mathrm{Pu}$, to 0.75 percent $235 \mathrm{U}$ when the reactor is producing 12 percent $240 \mathrm{Pu}$. For the Mark I-A fuel, the corresponding $235 \mathrm{U}$ average values are 1 percent and 0.85 percent. Natural uranium contains 0.71 percent ${ }^{235} \mathrm{U}$.

The wcights and dimensions given in the preceding paragraphs are typical; however, there are several minor deviations in cominton use for basically similar fuel elements.

Hcad-End Fucl Decladding and Dissolving

Decladding. The cladding is dissolved in a boiling mixture of ammontum fluoride and ammonium nitrate solution and is sent to underground waste tanks to await future evaporation to salt form.

As the cladding is dissolved, the exposed uranium is slowly attacked by the decladding solution and a smali amount of urantum fluorlde (UF 4 ) is formed. This collects in the dissolver as a solid (precipitate), some of which is carried with the cladding waste solution during removal from the dissolver. To prevent loss of this uranium to waste, the cladding solution is first centrifuged to recover the uranium and then sent to waste storage. 
The $\mathrm{UF}_{4}$ remaining in the dissolver is a potential source of hydrofluoric acid which would cause corrosion of the dissolver vessel if allowed to remain during the nitric acid dissolving of the declad fuel. To prevent this, the $U F_{4}$ remaining in the dissolver is converted (metathesized) to uranium hydroxide and potassium fluoride by the addition of potassium hydroxide to the dissolver. The potassium fluoride is highly water-soluble and is readily removed to waste storage with water rinses. The uranium is recovered and returned to the process. (The treatment and disposal of the high-level radioactive waste from the Purex process are discussed in detail in ERDA-1538.)

The off-gas from the decladding step contains hydrogen and ammonia, both kept well below their respective lower explosive limit concentrations by dilution with the large flow of process air through the system. The decladding off-gas stream is scrubbed with water, filtered and discharged to the atmosphere. The scrubber water containing the radionuclides is concentrated and sent to underground storage.

During cladding removal, the main flow of dissolver off-gas passes through two glass fiber filters in series and out the 291-A Exhaust Stack to the atmosphere.

Dissolving. After completion of decladding, the uranium is dissolved in nitric acid, and the metal solution is transferred to accountability and storage tanks in D Cell.

The off-gas from the dissolving step is heated by steam and electric neaters and passed through a silver reactor for the removal of radioiodine, then to the in-cell glass fiber filter, the 294-A Building secondary filter, and into the 293-A Building backup facility. In the 293-A Building, most of the remaining oxides of nitrogen are removed from the off-gas by two acid absorbers in series. The off-gas is then 
discharged via the main ventilation stack to the atmosphere. The dilute nitric acid produced in the absorbers is sent to the 206-A Building where it is concentrated and recycled to the process.

\section{Feed Preparation}

The metal solution from the dissolving step is given any needed adjustments in composition or concentration, and rework solutions (returned from subsequent process steps) containing products for recovery are added for recycle.

At this point, the solution ready to go to the solvent extraction cycles is a slightly acidic aqueous solution of uranium nitrate containing approximately $0.5 \mathrm{~g}$ of plutonium per liter and essentially all of the nonvolatile fission products and trace levels of neptunium.

\section{First Decontamination and Partition Cycle}

In this cycle, the uranium, neptunium and plutonium are extracted in the HA Column into an organic solvent to separate them from the bulk of the fission products and from the americium and curium that remain in the aqueous stream. This highly radioactive stream of aqueous waste is sent to B Plant for separation of strontium and cesium. This firstcycle waste stream routinely contains an average of 0.1 percent of the plutonfum, 0.05 to 0.08 percent of the uranium, 10 to 15 percent of the neptunium, and 99:99 percent of the fission products, plus the remainder of the transuranium elements initially. in the feed stream.

The uranium-plutonium-neptunium organic product stream then flows to the IBX Column and is contacted with a counter-current flow of aqueous phase. This aqueous phase contains a chemical reducing agent that causes the plutonium to transfer into the aqueous phase which then leaves the bottom of the column. The uranium and neptunium remain in the organic solvent stream that flows out the top of the column. 
This organic stream leaving the $1 \mathrm{BX}$ Column is fed to the $1 \mathrm{C}$ Column in which the uranium and neptunium are counter-currently stripped from the organic phase into a very dilute aqueous nitric acid stream. The used stripped solvent is chemically treated and prepared for recycle and reuse in the process.

The aqueous uranium product stream (containing most of the neptunium) leaving the $I C$ Column is only about 15 percent as concentrated as the starting metal feed solution. It is fed to a steam-heated concentrator where it is concentrated by a factor of 7 to 8 , with the overhead process condensate being recycled as part of the aqueous strip in the IC Column. The concentrator is designed and operated so that any entrained organic solvent that might enter with the $1 \mathrm{C}$ Column feed stream is removed overhead by the steam-stripping action of the vapors rising through the bubblecap trays of the tower. This prevents accumulation of an organic phase in the concentrator and reduces the probability of formation of the potentially explosive "red oil," a complex of nitrated degraded solvent with uranium or other heavy metais. $(1,2)$ Red oil can form and explode only if solution overconcentration occurs and if the uranium (or plutonium) concentration rises far above normal flowsheet value. Therefore, the concentrator steam supply is automatically controlled to $30 \mathrm{psig}$, limiting the temperature of the solution to a maximum of $275^{\circ} \mathrm{F}$. The steam coil condensate is sent to an underground crib via a line equipped with monitoring, diversion, and alarm capability to signal the failure and leakage of the coil and prevent or minimize release of radionuclides to the subsurface soil.

\section{Final Uranium Cycle}

The concentrated uranium product solution is adjusted as feed for the final uranium cycle. This cycle provides separation of the neptunium and final decontamination from plutonium and fission products; it consists of extraction into the organic phase in the 20 Column 
(analogous to the HA Column) followed by stripping back into the aqueous phase in the $2 E$ Column. The uranium product solution leaving the $2 E$ Column is concentrated and shipped to the Uranium Oxide Plant.

The final uranfum concentration step includes basically the same elements as described for the $1 C$ Column with the exception that the process condensate is sent to the 216-A-10. Underground Crib for final disposal instead of being backcycled within the process. This condensate stream is estimated to meet the limits of DOEM 0524 Appendix. Annex $\dot{A}$, Table II, when the radionuclide content of the stream, as discharged, is averaged over a period of one year as permitted by Section C.2 of DOEM 0524 Appendix.

The aqueous waste from the 20 Column contains the residual plutonium and fission products and essentially all the neptunium at this point. It is routed to the backcycle. waste concentrator from where part of it is returned and fed to the HA Column along with virgin feed metal solution; part of it is routed to the final neptunium cycle.

Second and Third Plutonium Cycles

The aqueous plutonium-bearing stream leaving the $\mathrm{BX}$ Column is contacted with organic solvent in the lB̈S Column for uranium decontamination. This organic stream is then recycled to the partition column feed tank and the aqueous plutonium stream is processed through a second extraction and stripping cycle for added purification from uranium, fission products and other metallic impurities. Nuclear criticality safety is maintained by a combination of limited plutonium concentration in solution and equipment geometry, with seven-inchdiameter columns. See Section III.l.4 for a summary of nuclear criticality prevention.

The third plutonium cycle, similar in principle to the second cycle but smaller in size, completes the purification of the plutonium product. 
The extraction (3A) and stripping (3B) columns, solvent stripping, product concentration, and batch accumulation facilities are in an integrated package in L Cel1. Nuclear criticality safety is provided by equipment design and geometry coupled with stream concentration and process flowsheet administrative controls.

The plutonium product stream from the $3 B$ Column is steam-stripped to remove residual organic solvent and reduce the probability of red oil formation; it is then concentrated to product level concentration, sampled, analyzed, and will be sent to the new plutonium conversion facility being built in the Purex Plant where the nitrate solution will be concentrated and converted into the oxide, sealed in containers and transferred to temporary storage or to the customer.

The overhead process condensates from stripper and concentrator containing trace amounts of plutonium are routed to the third plutonium cycle feed tank for rework. The cooling water from the respective condensers goes into the cooling water header and out to the surface pond.

\section{Neptunium Recovery}

The waste stream from the final uranium cycle contains most of the neptunium. It is collected along with other aqueous waste streams and concentrated in the backcycle waste concentrator from which part is sent to the HA Column and part to the neptunium recovery cycle in $\mathrm{J}$ Cell. Here, in a continuous extraction-stripping cycle, neptunium continues to accumulate as other nuclides (e.g., plutonium, uranium and fission products) are removed and returned to the backcycled waste system. This operation continues until the neptunium concentration reaches the desired 
level, after which it is transferred to the purification system in $Q$ Cel1. Here it is loaded on an ion exchange resin; washed to remove residual fission products, plutonium, etc.; and is then eluted from the resin and stored as a solution awaiting shipment offsite.

\section{Solvent Treatment}

The solvent ( 30 volume percent tributyl phosphate in a kerosenetype normal paraffin hydrocarbon as a diluent) is treated after use to remove impurities and chemical and radiolytic degradation products that interfere with proper process operation. Two separate systems are used. The first, located in $G$ Cell, processes all the solvent except that from the final uranium cycle. This is processed separately in the second system in $\mathrm{R}$ Cell because the required purity (decontamination) of the final uranium product is not attainable if treated solvent from the first system is used in the final uranium cycle.

One chemical wash treatment is made with dilute sodium carbonate solution in each of the two systems after which the solvents are slightly acidified with nitric acid and returned to the main process. The chemical wash wastes are combined and sent to underground tanks to await future evaporation to salt.

\section{Acid Recovery}

Nitric acid is one of the principal chemicals used in the Purex process. In addition to its function of dissolving the irradiated fuels, it is also used in the solvent extraction cycles where it heips to force the transfer of uranium (and plutonium) from the aqueous phase into the organic extractant. Because of its large-volume use, it is recovered and reused as much as possible.

Acid recovery from the dissolving cycle has previously been summarized. Another major recovery source is the aqueous high-acid waste from the solvent extraction cycles. Oxides of nitrogen are 
produced by the deacidification and partial denitration of this waste, and are converted in an absorber to an aqueous solution of 25 weight percent $\mathrm{HNO}_{3}$. This is fed to the acid fractionator in the 206-A Building along with dilute acid streams returned from the dissolver off-gas facility (293-A Building) and the 50 weight percent $\mathrm{HNO}_{3}$ from the Uranium Oxide Plant. The fractionator operates under a partial vacuum, continuously concentrating the 25 percent acid to 50 weight percent acid; this is then stored in $U$ Cell and subsequently returned to the dissolvers and the solvent extraction streams.

The $\mathrm{F}$ Cell acid absorber releases a small amount of oxides of nitrogen to the vessel vent system and from there to the atmosphere via the main ventilation stack. This amounts to approximately 250 to $300 \mathrm{~g}$ of $\mathrm{NO}_{x}$ per minute, or about 50 to 60 parts per million (ppm) in the flow of air leaving the stack. The process condensate from the acid fractionator is recycled to the acid fractionator, the condensate recycle system and the back-up facility. The steam condensate goes directly to the Purex chemical sewer and then to B-Pond.

\section{Waste Treatment - High Level Waste}

The aqueous waste from the HA Column contains a significant fraction of the halogens and tritium, and essentially all of the fission products except the fission gases that enter the Purex process. It also contains all of the nitric acid fed to solvent extraction except that associated with the various product streams as discussed in the preceding paragraphs. This waste s.tream is routed.to the high-level waste concentrator feed tank, diluted to enhance acid recovery, and is then sent to the waste concentrator.

The concentrated waste, partially deacidified by boiling acid overhead as described in the preceding discussion, overflows continuously from the concentrator to a waste receiver tank. After it has been sampled, analyzed, and confirmed for transfer, it is partially 
denitrated by the addition of sugar solution. The gases produced, principally carbon dioxide and oxides of nitrogen, are routed back to the vapor tower of the concentrator, and up to 50 percent of the oxides of nitrogen are recovered as nitric acid.

The concentrated, deacidified waste. is transferred from the Purex Plant to B Plant for fission product separation.

\section{Backeycle Waste}

The backcycle waste system accumulates product-bearing aqueous waste streams from the uranium, plutonium and neptunium cycles following the partition cycle. This waste is concentrated by a factor of 6 to 7 and recycled to the solvent extraction process. This provides recovery of products lost from the individual product purification cycles by reextraction in the $H A$ Column. The backcycle waste system also furnishes feed solution to the second neptunium cycle and provides the nitric acid needed for efficient extraction operation of the HA Column.

The overhead condensate from the waste concentrator was formerly discarded to an underground crib, but is now routed to a concentrator where it is reevaporated along with the principal uranium product stream as part of the Purex condensate recycle program.

\section{II.3.1.4 Water Use, Services and Utilities}

Water

Water for the Purex Plant is drawn from the Columbia River and pumped to the 282-E Building in 200 East Area from B Reactor pumphouse with $D$ Reactor pumphouse as backup. Dual supply mains are also available on this export system, which supplies both the 200 East Area and the 200 West Area. 
The 282-E Building raw water system consists of a 3-million-gallon reservoir and five pumps having a combined capacity of 28,000 gallons per minute $(\mathrm{gpm})$.

The sanitary water system treatment and pumping facilities are located in the 283-E Building, and are supplied by the raw water system. The sanitary system consists of the usual treatment facilities, including a 400,000-gallon clear well and five pumps. Both raw and sanitary water systems supply the Purex Plant. Normal supply rates during Purex process operations are 7,000 gpm and $300 \mathrm{gpm}$ for the raw water and sanitary water, respectively. Total raw water demand in 200 East Area is approximately 18.5 million gallons per day (Mgd) and sanitary water total demand is about $1.5 \mathrm{Mgd}$.

A 50,000-gallon high tank, located about 250 feet northwest of the 202-A Building, supplies the water required for emergency use in case of interruptions in normal supply. Analys is of flow tests indicates that the Purex Plant water supply is adequate for current and projected protection needs.

The pumping facilities for both the raw water and sanitary systems are arranged to sound an alarm in the powerhouse (284-E Building) in the event of abnormally low water pressure conditions.

\section{Electric Power}

Electric power is supplied to Purex Plant through the 251-W Substation, which is located about four miles northwest of the Purex area. Incoming power to the substation is supplied by the Bonneville Power Administration by two parallel 230-kilovolt (kV) 1 ines.

There have been few power outages in more than 20 years; the maximum outage lasted five minutes. The power supply to the 251-W Substation is considered reliable. 
From the 251-W Substation, the Purex Plant is supplied by two 13.8-kV overhead lines. If one line becomes impaired, the load is automatically switched to the other line. A third line is available but requires manual switching at the plant.

An emergency power supply is also available from the 200 East Area powerhouse steam turbine generator. Supply from this 750-kilowatt (kW) generator at 2,300 volts is automatically switched to the Purex emergency circuit to supply two 500-kilovolt-ampere (kVA) transformers. These transformers are normally on the line, but are needed only in the event of the use of the emergency power supply. The power system on the emergency circuits is connected to the instrument air compressors to ensure the air supply necessary for a safe shutdown.

Having two 3,750-kVA transformers helps ensure against plant shutdown since one transformer, in combination with the emergency power supply, is capable of carrying the plant load.

\section{Compressed Air}

Service air is supplied by two compressors with a third on standby. This air, at 100 pounds per square inch (psi), is used for operating sampler jets, blowing out transfer lines, operating steam jets in case of steam supply failure or blockage, and blowing water from coils. When the steam coils in the concentrators are not in use (i.e., when the steam is turned off) air pressure is automatically applied inside the coils. This effectively prevents radionuclides from leaking into the coils from the process side if holes should develop in the coil walls, and thereby prevents contamination of subsequent cooling water and/or steam condensates. 
Instrument air is supplied at 80 psi by one of two compressors each with a capacity of 370 standard cubic feet per minute (scfm). The air is dried and distributed through pipes in the gallery to points of use. The compressors are connected to the emergency electrical supply system so that there will be instrument air available at all times. The second compressor is on standby.

Air mask breathing air is supplied at 50 psi by another compressor with a capacity of $105 \mathrm{scfm}$. The air is passed through a water separator and a filter to piping that serves the sample gallery, laboratory, regulated shop, railroad tunnel, decontamination cell, hot shop, PR Room, 276-A Building, crane maintenance platform, acid storage vault and the laboratory ventilation equipment room.

\section{Vacuum System}

The vacuum system consists of two, 940-scfm water-sealed rotary vacuum pumps located in the Sample Gallery. It supplies the vacuum for a network of 150 air samplers positioned throughout the canyon proper, the sample and operating galleries, unregulated service areas, laboratories, and the 202-A Building vent stacks (excluding the main ventilation exhaust stack). Because the air samplers monitor the air for radionuclide content, the vacuum pumps are connected to the emergency electrical supply.

\section{Steam}

Steam used in the Purex Plant is produced in the 200 East Area powerhouse (284-E Building) by three 80,000-pound-per-hour (1b/hr) and two $90,000 \mathrm{ib} / \mathrm{hr}$ stoker-fired boilers at $250 \mathrm{psi}$. Under maximum steam demand conditions, one boiler is available on a standby basis. Steam produced in the 284-E Building also operates an automatic steam-driven 
750-kW generator located in the building that supplies emergency power to the Purex Plant and other facilities in the 200 East Area.

Purex Plant steam use during full operation averages 100,000 to $125,000 \mathrm{lb} / \mathrm{hr}$; most of this is used in the process solution concentrators (evaporators). Other uses are for heating and ventilating, process steam jets and outside facilities. High-pressure steam is supplied to the canyon's emergency exhaust ventilation turbine-driven fan before the steam line enters the 202-A Building. This turbine has priority demand on the high-pressure steam, and if other demands reduce the pressure on the turbine system below an established minimum, the other uses are throttled back to maintain this minimum.

\section{Fire Protection Systems}

The Purex 202-A Building is a heavy-walled reinforced concrete structure with a poured concrete roof. The roof is a minimum of 12 inches thick and is built up with asphalt and gravel. The 202 Annex Building is steel and transite construction also with a built-up asphalt roof.

In the 202-A Building the RT-A Tank (fresh makeup solvent) and most of the canyon cells, especially those containing the large inventories of organic solvent (viz., G, R, H, J and K Cells) are equipped with an automatic sprinkler foam system using the "Light Water" $(R)$ aqueous film forming foam system which simultaneously applies foam to the adjoining air exhaust tunnel. Detection of fire in these cells is by ratecompensated thermal detectors that sound alarms locally and at the central fire station between 200 East and 200 West Areas. Detectors are spaced approximately every 20 feet and are tested and supervised. Fire fighting personnel and equipment can arrive on the scene from the central fire station located midway between the 200 Areas within six minutes.

(R) Registered, 3M Company, Inc. 
Fire protection in the other canyon process cells is provided by a system of peripherally mounted spray nozzles controlled by manual gate valves. The nozzles were installed at the time of construction and are mounted at 9- to 12-foot spacings in the cells.

Manual actuation of the systems is dependent upon the detection of abnormal conditions by photoelectric flame detectors, set approximately every 40 feet through the cells. The fire detection units actuate alarms in the central control room and in the dispatcher's office.

An automatic water spray system in the main ventilation exhaust tunnel, presently under construction, will prevent heat and burning material coming from a fire in a process cell from reaching the 291-A Building exhaust filters.

Fire detection and suppression (Halon 1301) will be installed in the canyon cranes.

Automatic sprinkler protection on standard wet and dry pipe systems is installed in the "hot" shop and the storage portion of the storage gallery in the canyon building. In addition, $N$ Cell, Q Cell and the plutonium storage area, have automatic wet pipe sprinklers with both local and 200 Area central fire station alarms. All sprinkler installations are low-temperature closed-head systems.

Automatic sprinkler protection on standard wet and dry pipe systems is also installed in the 202 Annex Building, including the laboratories, laboratory storage area, aqueous makeup area, offices and shops.

All fire protection valves and flow systems are inspected monthly and tested at least annually, for critical components such as primary valves that control water to the fire protection systems. The inspection and test procedures meet the requirements of the DOE formal subject guide. 


\section{II.3.1.5 Radioactive Effluents and Solid Waste}

Radioactive contaminated materials are discharged from the Purex Plant in liquid, gaseous and solid form. The products (uranium, plutonium and neptunium) are packaged and moved under controlled conditions without significant environmental impacts to other onsite or offsite locations. Waste is handled according to form and composition. The principal radionuclides released in gaseous waste are tritium $\left({ }^{3} \mathrm{H}\right)$ and the noble gases, mainly ${ }^{85} \mathrm{kr}$, with minor amounts of others such as fission products and activated nuclides. Liquid and solid wastes generally contain a broad spectrum of reactor-produced radionuclides, but composition and concentrations vary widely depending on the origin and type of waste.

\section{Liquid Effluents}

The principal low-level radioactive liquid effluents from the Purex Plant are shown in the schematic diagram of Figure II.9. (The highlevel wastes are summarized in Section II.2.1 and discussed in detail in ERDA-1538.)

The largest-volume effluent streams are the process cooling water (2.6 billion gallons per year) and the chemical sewer waste ( 280 million gal/yr). The steam condensate averages 60 to 65 million gallons annually; process condensates and ammonia scrubber waste are less than 10 million gal/yr.

Cooling water and chemical. sewer waste do not have direct contact with process solutions and are disposed of to surface ponds as shown in the schematic diagram. The potential does exist for contamination of the chemical sewer effluent, e.g., with acid fractionator steam condensate. The resultant concentration has been determined to be within the values specified in DOEM 0524 Appendix, Annex A. Nevertheless, 
the chemical sewer stream will be equipped with radiation monitoring instruments, alarms and control diversion valves that will automatically signal the presence of radionuclide contamination and divert the contaminated effluent to a covered receiver basin from which it can be returned to the 202-A Building. This is illustrated by the dashed 1 ines in Figure II.9.

Steam condensate does not come in contact with process solutions and is contamination free except for residual contamination in the pipe caused by an earlier heat exchanger failure. This stream routinely meets the limits of DOEM 0524, Appendix A, Table II. However, because of both the line contamination and the possibility of steam coil leaks, the steam condensate is sent to the 216-A-30 Crib (as shown in Figure II.9) even though it routinely contains less than $5 \mathrm{Ci}$ of total radionuclides annual1y. These discharge lines are equipped with radiation monitors and the capability of diverting the contaminated water to the covered receiver basin.

Ammonia scrubber waste, which ranges from 4 to 6 million gallons annually and contains a total of less than $300 \mathrm{Ci}$ of tritium and less than $5 \mathrm{Ci}$ of combined fission product and transuranic nuclides, is evaporated to reduce the amount of radionuclides discharged to the soil. The condensate from this step is routed to the 216-A-36B Crib. Since it is possible that the condensate may occasionally be contaminated, this stream will also be equipped with improved monitoring and diversion capability. The concentrated liquid from the evaporator contains essentially all the radionuclides and is sent to an underground storage tank. 


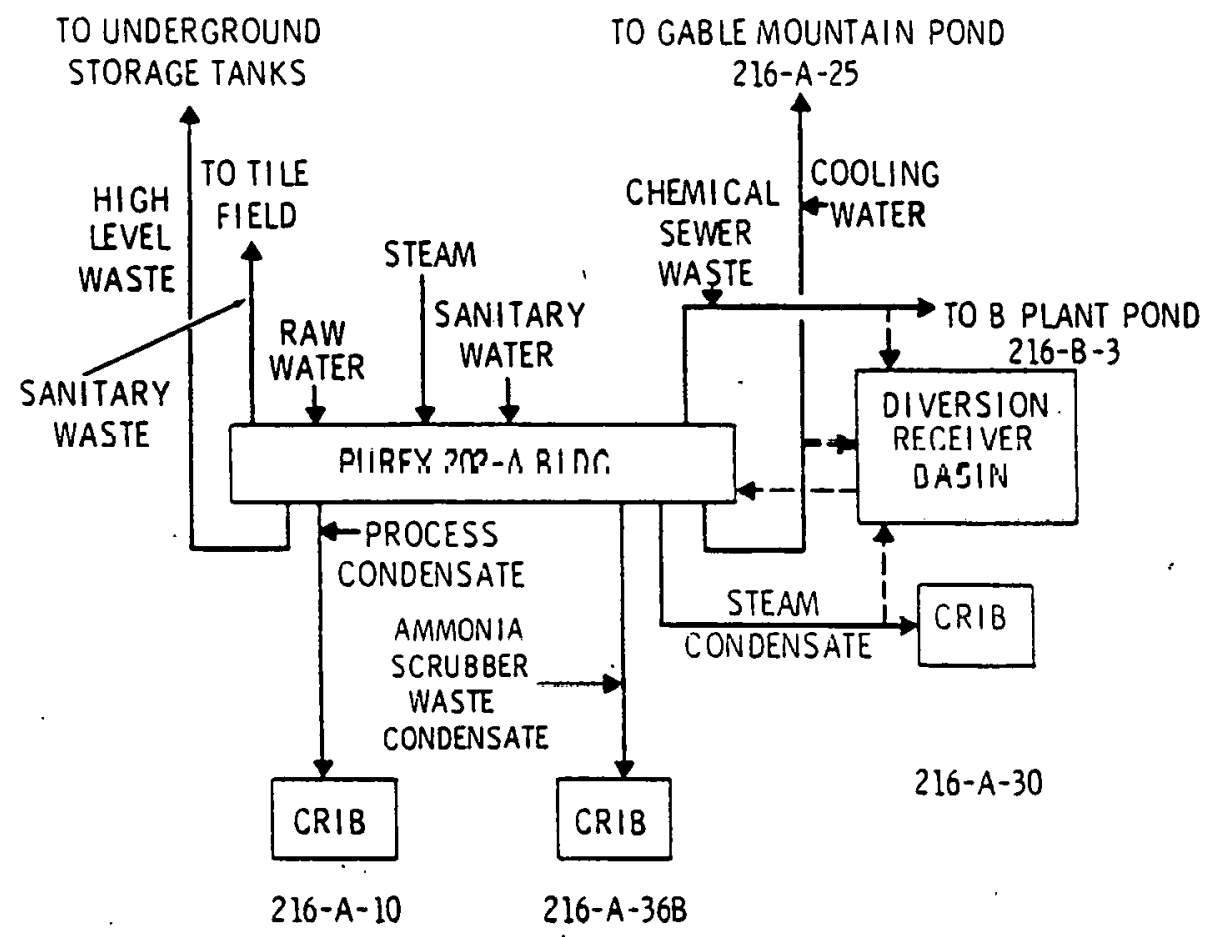

\section{FIGURE II.9}

SIMPLIFIED SCHEMATIC DIAGRAM OF THE PUREX PLANT LIQUID EFFLUENTS

Process condensates are generated at severat points in the Purex process and, with the exception of that from the final uranium cycle concentrator, are continuously reevaporated and recycled within the plant. This final uranium evaporator condensate, with a volume of 2 to $4 \mathrm{million}$ gal/yr, contains up to $17,000 \mathrm{Ci}$ of tritium and less than $0.5^{\mathrm{C}} \mathrm{C}$ of combined fission product and transuranic radionuclides. It is sent to the 216-A-10 Crib with flow measurement, composite sampling and analysis. Continuous in-line radionuclide monitoring will be provided. 
All liquid streams continuously discharged either have, or will have, composite samplers and continuous flow measurement with totalizing capabilities prior to discharge. As noted earlier, the cooling water and steam condensate streams are continuously monitored and can be diverted to a receiver basin for recycle back to Purex.

Detailed discussions of Hanford Reservation hydrology and descriptions of waste liquid effluent disposal methods and locations are given in Section II.1 of ERDA-1538.

\section{Gaseous Effluents}

Approximately $1.2 \times 10^{11}$ cubic feet $\left(\mathrm{ft}^{3}\right)$ of gases are discharged from the Purex Plant annually, containing an average of $0.5 \mathrm{Ci}$. of fission products and transuranic nuclides plus about $900 \mathrm{Ci}$ of tritium. The principal sources and points of discharge from the 202-A Building are shown in Figure II.10. All streams, except effluents from the third ventilation system (described later) which are basically noncontaminated under normal operating conditions, are filtered before release to the atmosphere as illustrated in Figure II.10 and described below. Filtered exhaust will be added to the third system before plant startup. All radionuclide contaminated effluents are monitored, sampled and analyzed for radioactivity (see Section II.3.1.7). Effluents from the ma.jor stacks are analyzed for specific radionuclides. 


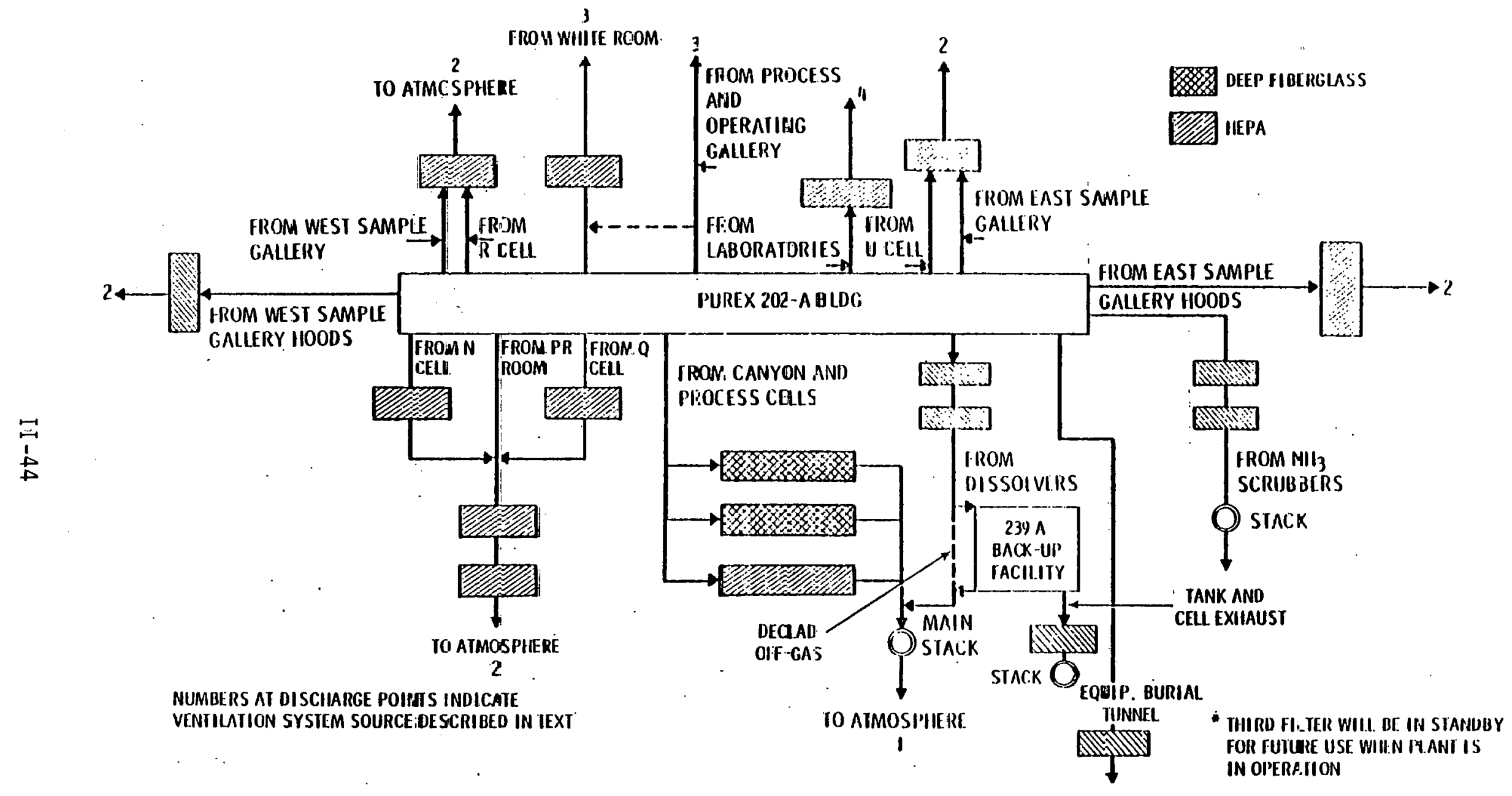

FIGURE II 10

SIMPLIFIED SCHEMATI: DIAL̈RAM OF THE PUREX PLANT GASEOUS EFFLUENTS 
Ventilation Systems

The 202-A Building is serviced by four separate ventilation systems designed and operated so that normal work areas are kept free of radioactive contamination by maintaining air flows from zones of no radionuclide content into zones of progressively greater radioactivity contamination potential.

First Ventilation System. This main system serves the canyon, east crane maintenance platform, Burial Tunnel number 1 , process cells, and process vesse1s which are the areas of greatest radioactivity potential. The air supplied near the canyon ceiling is exhausted near the bottom of the cells into the wind tunnel, through the 291-A Building filters and out the main stack. Jets are used to pull a vacuum on process vessels and condensers. The resulting air stream passes through a condenser, a steam heater and an in-cell filter to the wind tunnel.

The two 291-A Building filters are operated in parallel. Their efficiencies have been tested with particles ranging from 0.3 to 0.7 -micron mean aerodynamic diameter, and have been found to range from 99.1 to 99.9 percent with an average of 99.6 percent. They will be tested annually when the plant is in operation. They are of similar design, but with significant differences. Each has two glass fiber bed sections, the prefilters, and the cleanup filters. In the first unit, the prefilter is one bed, seven feet deep, packed w1th 115-K Fiberglas. In the second unit, the prefilter consists of five separate layers, each packed to a different density of Fiberglas. The cleanup filter in each unit consists of 132 American Air Filter Company "Deep Bed Filter" units one inch thick with a total area of approximately $50 \mathrm{ft}^{2}$ per unit. The prefilter section provides insurance against water carry-over to the clearup filter. The fllters are designed and sized to operate at an

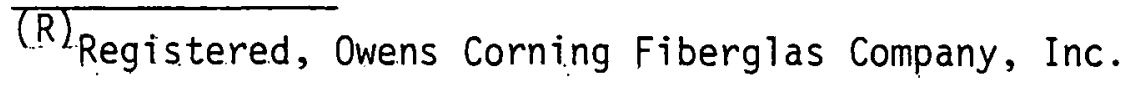


air velocity of 50 feet per minute. Filter tests will be conducted annualiy to check performance and efficiency following the resumption of plant processing operations.

A resent.ly completed high efficiency particulate air (HEPA) exhaust filter is installed in parallel with the two deep bed glass fiber filters, and will be ready for use (backup) if the deep bed glass fiber filters undergo a reduction in efficiency.

This third filter cell is equipped with two banks of 85 percent ASHRAE* bag-type prefilters in series and three banks of HEPA filters in series. The two banks of prefilters and the first bank of HEPA filters are designed to permit the upper one-quarter of the filter banks to be lowered; the remaining three-quarters of the bank will remain in place. This feature permits bypassing of a bank or banks of filters if excessive pressure drop across the filters occurs due to particulate loading. The final two banks of HEPA filters are permanently mounted.

The design of the filter exit air duct includes a water seal, which when filled with water will stop airflow through the filter and remove the filter from service. The exit duct seal water is supplied from a sledill-lied led and insulated storage tank of 10,000-gallon capacity. The seal will bc fillcd by gravity discharge of the storage tank rontentc through a motor-operated valve. The valve is activated automatically by a fire detection element located in the inlet duct to the filter, or by a manually operated switch located in the 291-A Sample House.

\footnotetext{
*American Society of Heating, Refrigerating and Air-Conditioning Engineers.
} 
Electropneumatic instrumentation is provided to monitor differential. pressure across the filter, the individual filter banks, and the fire screen in the filter inlet duct. Indicating differential pressure instruments and high-level alarm switches are located in Sample House 4. Differential pressures in excess of established control limits are annunciated in the Power Unit Control Room in the 202-A Building.

Exhaust gas from the dissolvers is continuously monitored for radioiodine and is routed through separate glass fiber filters to the main stack (291-A Building). These filters are rated as 99.9 percent efficient for particulates of 0.7 micron or larger diameter.

Four exhaust fans in parallel are located near the base of the 291-A Building stack. The exhaust load is normally 125,000 cfm carried by the three electrically driven fans; these are backed up by an automatic emergency steam turbine that can maintain an adequately safe minimum canyon exhaust flow rate of $63,000 \mathrm{cfm}$. The main ventilation stack is 200 feet tal1, rising approximately 140 feet above the roof level of the 202-A Building. It is constructed of reinforced concrete, and contains a free-standing stainless steel liner, having an inside diameter of seven feet, through which the exhaust air is discharged to the environment at a velocity of about 3,100 feet per minute $(\mathrm{fpm})$. The annulus between stack and liner is capped at the top. The main ventilation stack is equipped with a moving tape betagamma radiation monitor, an iodine monitor, and two sampling systems: one at the 50-foot level for record samples, and one at the 196-foot level for process control purposes.

The primary ventilation exhaust stream from building canyon and cells represents 50 to 55 percent of the total volume of air discharged from the Purex Plant, and more than 90 percent of the total radionuclides released in the gaseous effluents. 
With the exception of ${ }^{14} \mathrm{C},{ }^{3} \mathrm{H}$ and ${ }^{85} \mathrm{Kr}$, the radionuclide concentrations in this main exhaust stream discharged through the existing main filters, are routinely at or below the values of DOEM 0524 Appendix, Annex A. Table I. A recentiy completed HEPA ventilation exhaust filter will be ready for standby (backup) use when the Purex Plant resumes operations. It will operate in parallel with the existing filters. With this filter in use, radionuclide concentrations (except ${ }^{3} \mathrm{H},{ }^{14} \mathrm{C}$ and ${ }^{85} \mathrm{Kr}$ ) in the exhaust stream will be reduced. All radionuclide concentrations in the air are calculated to be below Table II limits at the Hanford Reservätion boundary.

Second Ventilation system. This system services the areas of the building that are routinely occupied or entered by the work force, but are regulated because of a potential for contamination. The supply system consists of two fans, rated at 38,000 $\mathrm{dfm}$ each, which are operated one at a time for normal service; they supply air to the sample gallery, regulated shop, $\mathrm{N}$ Cell, Q Cel1, PR Room, PR Corridor and the canyon lobby. There are six exhaust fans for these areas. The first fan exhausts the east sample gallery and $U$ Cell; the second fan exhausts the west sample gallery, $R$ Cell, the regulated shop and the canyon lobby; the third fan exhausts the east sample gallery hoods; the fourth fan exhausts the west sample gallery hoods; the fifth fan exhausts the PR Room, Q Cell and $N$ Cell areas. The sixth fan is a backup for the fifth. The effluents discharged by the first four fans pass thruugh d single bank of HEPA filters, and the effluent from the fifth and sixth passes through two banks of HEPA filters in series. The two PR Room exhaust fans are equipped with automatic changeover switchgear and dampers so that if one fails in service, the other will start. The radionuclide concentrations in all of these effluents are below the concentration limits specified in DOEM 0524 Appendix, Annex A. 
Radiation monitoring capability will be available for the PR Room, east sample gallery hood and west sample gallery hood exhausts.

Third Ventilation System. This system services the pipe and operating gallery area, the storage gallery, the pulser motor-generator room, the aqueous makeup area, the services and shops and office areas, all of which are noncontaminated; these, moreover, are considered to have the lowest potential for becoming contaminated. The air from the service areas is exhausted unfiltered by small local exhaust fans. The west end of the pipe and operating gallery (the "white room") is sampled and exhausted via a blower fan to a 70-foot-high stack. Continuous air monitors with alarms are located in areas with potential for becoming contaminated. As supplemental environmental protection assurance, a filtered exhaust system will be added to this third system - the pipe and operating gallery - before or soon after resumption of plant process operations. In the interim, special precautions will be taken. to enhance radionuclide containment within the gallery, and constant air monitoring of the gallery will be provided.

Fourth Ventilation System. This system services the Purex laboratory area and is largely independent of the other systems. The air supply consists of two sets of ventilating equipment connected in parallel. Each set is sized to handle 100 percent of the requirements with one set in standby position. The exhaust air from the laboratory hoods and decontamination room is exhausted by a main fan (with one in standby) through one bank of HEPA filters into a plenum chamber and then through a stack on the roof to the atmosphere. The air from all offices and shops is exhausted into the corridor which is in turn exhausted through 
the rooms with open-face hoods. This assures an air flow from the less contaminated areas to the more contaminated areas. Both exhaust fans are connected to the emergency power system and equipped for automatic changeover upon failure of normal power supply. The effluent is sampled, and based on 1972 experience, will be less than the DOEM 0524 Appendix, Annex A, Table I concentrations at the point of discharge to the atmosphere and Table II concentrations at the Reservation boundary.

Ammonia Scrubber Ventilation System

A new ammonia scrubber system has been installed in the 202-A Building, the off-gas from which is passed through two HEPA filters before being discharged through its own new 80 -foot-high stack. It is "anticipated that the off-gas will be less than DOEM 0524 Appendix, Annex A, guides in view of the combined efforts of the scrubber systems and the double filtration of the off-gas. The stack is equipped with a continuous ammonia analyzer and a continuous beta-gamma monitor.

\section{Burial Tunnel Ventilation System}

- Major pieces of equipment are placed on old railroad flat cars for storage in Burial Tunnel number 2 at the east end of the Purex Plant. Air is drawn through the tunnel and exhausted through a single HEPA filter, with exhaust air samples taken weekly. Analyses show that the

- Table II values are met at the Reservation boundary. The duct for Burial Tunnel number 1 is blanked. The only ventilation is through the partially sealed door to the railroad tunnel, which is vented to the canyon and/or Burial Tunnel number 2 as determined by differential pressures in the area.

\section{Dissolver Backup Ventilation System}

The Backup Facility (293-A Building) is separate from the main Purex structure and contains scrubbers and filters for the dissolver off-gas. The gas is sampled and exhausted through a single HEPA filter by a blower fan to a 50-foot-high stack. 
Solid Waste

Solid radioactive wastes generated in the Purex Plant consist primarily of failed and unusable equipment; tools and other supplies; laboratory equipment and other contaminated materials. Transuranic (TRU) wastes are those contaminated with, or suspected of being contaminated with, greater than 10 nanocuries of transuranic radionuclides per gram of waste. These are placed in storage such that the waste packages may be retrieved free from external contamination for a 20-year period. Nontransuranic wastes go to permanent disposal by shallow land burial.

Items of failed process equipment that are too large, too bulky and too radioactive to be removed from the plant for the immediate future, are put on old railroad cars and placed in the Purex equipment burial tunnel for indefinite storage. Exhaust ventilation air from the tunnel is filtered and discharged to the atmosphere. Large waste items for immediate disposal may be placed in wood, concrete or metal boxes and buried in a 200 East Area burial ground. Smaller items of process equipment or other highly radioactive solid waste are collected in the canyon in a large carbon steel container that, when full, is placed in a concrete container with a lid and buried in a 200 Area burial ground. These boxes may be constructed for 20-year storage for TRU wastes. Radioactive solids of small bulk and relatively low levels of activity are collected and either put into 55-gallon drums for 20-year retrievable storage if they are TRU wastes, or put into boxes or drums for burial if they are non-TRU wastes. The drums meet the requirements of the Department of Transportation, Container Specification 17-C. Title 49 CFR 178.118.

Solid waste effluents (excluding those that are handled remotely) are monitored by beta and gamma instruments for radiation level. A neutron monitor is used to measure plutonium in dry waste containers 
to determine whether the waste is to be discarded or reprocessed for plutonium reclamation. The plutonium mass limit is $200 \mathrm{~g}$ for an individual drum to be buried for 20-year retrievable storage on an asphalt pad.

The Purex flant nontransuranic wastc (approximatcly $16,000 \mathrm{ft}^{3}$ in 1972) is buried in the 200 East Area industrial burial ground. The transuranic waste (approximately $6,700 \mathrm{ft}^{3}$ in 1972) is put into 20-year retrievable storage in the 200 West Area.

\section{II.3.1.6 Nonradioactive [ffluents and Solid Waste}

\section{Liquid Effluents}

Waste from drinking water fountains, toilets, showers and other miscellaneous nonradiation nonprocess uses, is discharged via the sanitary sewer system to a septic tank tile field about 1,500 feet north of the 202-A Building. The volume is about 10 percent of the total Purex Plant sanitary water usage. The balance is discharged to cribs and ponds through the various process routes.

Chemical waste is released via the chemical sewer to the 216-B-3 Pond. This waste contains small amounts of process chemicals from spills, floor flushes, discards in chemical preparations, etc., and from regeneration of the water demineralizers. It is released untreated but when the new capability is installed it can be diverted to the covered retention basin if it becomes unexpectedly contaminated with radioactive nuclides.

\section{Solid Wastee}

Nonradioactive solid waste consists of ordinary trash (primarily paper) and is about 97 percent combustible. Such waste is collected in specified bins, compacted to approximately one-third volume and buried in the Hanford Reservation central sanitary landfill. 


\section{II.3.1.7 Effluent and Process Monitoring}

The functions of the instrument and radiological protection systems are to monitor and control process operation, to protect working personnel and the public against accidental radiation exposure, and to verify proper functioning of the safety systems in the plant operations.

\section{Effluent Monitors}

Monitors for air and airborne particulates are placed at selected locations throughout the facility based on the functions of the areas, the presence of radionuclides, and the ventilation air flow patterns. The monitors are of different types depending on their locations. Some, such as the iodine monitors in the dissolver cells and 293-A Backup Facility, continuously monitor a sidestream sample of the air flow and give an alarm in the head-end control room if the air contamination level rises above a set value. Others, such as those on the PR room and $Q$ Cell effluents, monitor a fixed filter through which a sidestream sample is continuously drawn. The results are recorded in the control room and indicated in the dispatcher's office with both a visual and audible alarm to signal higher-than-normal values. Still others (viz., $R$ and $U$ Cells, east and west sample gallery exhaust, laboratory exhaust duct, pipe and operating gallery, and Burial Tunnel number 2) consist of a fixed filter through which a sidestream sample of the effluent (inventory sample) is drawn for a fixed period of time (e.g., seven days), and which is then removed for determination of its radionuclide content by a counting instrument.

The main ventilation stack, which carries the combined effluents from the canyon ventilation, the vessel and condenser vents and the treated dissolver off-gas, is equipped with a moving tape monitor system and with two inventory systems, one at the 50-foot level and one at the 196-foot level. A new sampling, monitoring and flow totalizing system (refer to Section II.3.1.8) is being designed for installation prior to Purex startup. Similar equipment is planned for the PR stack. 
Liquid effluents (excluding sanitary and high-level radioactive wastes) from the Purex 202-A Building are process condensates, steam condensates, cooling water, ammonia scrubber and chemical sewer waste. Since completion of the condensate recycle project (see II.3.1.8), only one process condensate stream (that from the final uranium concentrator) is released to a crib. This goes to the 216-A-10 Crib. Analyses of the liquid effluent streams will be made weekly on proportional samples when plant operation resumes. Because the potential for radionuclide contamination above DOEM 0524 Appendix. Annex A, Table I limits is low for this condensate, weekly samples are considered adequate. Improvements in flow rate and volume measurements, monitoring capability, and sample collection will be installed prior to Purex Plant startup.

Steam condensates to the 216-A-30 Crib and cooling water to the 216-B-3 and 216-A-25 Ponds are monitored by radiation instruments (with recorders and alarms in the dispatcher's office) that automatically divert the stream flow away from cribs or surface ponds to a covered retention basin if concentrations of radioactive material above established limits are detected in the effluent. The automatic response levels are set at the midpoint of the monitoring instrument's rangc or above. This is high enough to be above the expected maximum in the range of normal variation in radionuclide concentration during normal operations so as to minimize false alarms. The chemical sewer effluent contains air compressor and acid fractionator cooling water, aqueous chemical makeup spills, floor flushes from nonradiation zones, and acid fractionator steam condensate. Its disposal point is the 216-B-3 Pond: Monitoring is being added to the chemical sewer and ammonia scrubber concentrator condensate effluents. The chemical sewer system will be equipped with automatic diversion capability. 


\section{Personnel Monitors}

Instruments and systems for monitoring radioactivity and radiation levels are located throughout the facilities. Portal monitors are installed at appropriate exits and on the sides of some corridors. Hand-held monitors and probes are provided for surveys on entering and leaving areas which are normally free of contamination, but in which there exists the potential for contamination to occur. Hand and foot monitors are installed near the exits from the change rooms and established radiation control zones. Portable instruments are used for measuring alpha, beta, gamma and neutron radiation in conjunction with sampling and counting techniques in the laboratory.

\section{Building Monitors}

There are more than 50 ionization chamber monitors located throughout the facility to provide complete coverage of areas in which the probability of radiation is highest. The building monitors indicate, record and alarm both locally and in the dispatcher's office. In addition, there are three special Pico-amp $(R)$ meters with recorders in the dispatcher's office, and with ionization chambers in $N$ and $Q$ Cells and the PR Room areas. These are capable of automatically recording radiation levels from 0.001 to 1,000 roentgens per hour.

\section{Process Monitoring Instrumentation}

In the Purex process, specifications and operating limits have been established for every stream, every component and every point in the operations, as required to ensure safe operations in the production of specification products. The function of the various instrument systems is to correctly indicate and allow proper assessment by operating personnel of operating conditions on a continuous basis.

Remote control of most of the Purex process is necessitated by the intense radioactivity of the material and the massive radiation shielding (R) Registered, General Electric Company. 
between people and process areas. This requires remote instrumentation, most of which terminates in the head-end and central control rooms that are continuously manned during process operations.

ihere are three levels of data recording and display. The first level includes measurements essential to safe operation of the facility. These are displayed, recorded, controlled and alarmed in the control rooms. The second level involves measurements necessary for the normal operation of the plant. These readings include radiation measurements in potenclally contaminated effluent systems, as weil as principal operational parameters. These data are recorded and alarmed in the control rooms. The third level includes measurements of noncritical parameters for operation of the facility. These are displayed on local instruments or alarmed in the control rooms.

\section{II.3.1.8 Modifications to Purex Facilities}

\section{Improvements Cuimpleted}

Projects and actions completed since the preparation of ERDA-1538 are discussed in the following paragraphs.

\section{- Liquid Effluent Control Improvements}

Steam condensate and cooling water streams have been $\$ 400,000$ equipped with automatic monitoring and valving to detect and divert contaminated water into a new covered retention basin for return to the Purex Plant for reprocessing. This provides added protection for the cnvironment against accidental releases.

A system was installed to provide routine internal $\$ 460,000$ recycle and reevaporation of the condensates from the acid absorber, acid fractionator, the backcycle waste concentrator and the first uranium cycle concentrator: This leaves only one stream 
that is routinely discharged to the $216-\mathrm{A}-10 \mathrm{Crib}$. This represents a reduction in the radionuclides released to ground by factors of from 50 to 300 for some of the principal fission products and plutonium. This project installed a new routing for ammonia scrubber waste from the dissolver cells and from $\mathrm{E}$ Cell to an evaporator in $\mathrm{F}$ Cell rather than to the underground soil (the 216-A-36-B Crib). The concentrated waste goes to an underground storage tank; the condensate goes to the crib and is expected to meet the concentration guides of DOEM 0524 Appendix, Annex A, Table II. This is lower than the former waste in radionuclide content by a factor of $10^{3}$ for plutonium and up to $10^{4}$ for specific fission products. (The off-gas from the $F \mathrm{Cell}$ evaporator and condenser go through a new HEPA filter and a new exhaust stack to the atmosphere.)

- Gaseous Effluent Control Improvements

Single-stage HEPA filtration was installed on the $\$ 247,000$ formerly unfiltered exhaust air from $R$ Cell, $U$ Cell and the sample gallery of the 202-A Building. These effluents are expected to meet the concentration guides of DOEM 0524 Appendix, Annex A, Table II. The project provides protection against accidental releases to the environs as a result of an abnormal event.

A second stage of HEPA filtration was added to the $\$ 62,000$ effluent from the PR Room to reduce routine radionuclide releases to less than Table II limits and provide protection against accidental releases. The new filter also provides a third stage of HEPA filtration for the $N$ and $Q$ Cell exhaust streams. 
A new off-gas handling system provides for the $\$ 695,000$

E Cell ammonia scrubber; it includes heater, filter, sampler, ammonia analyzer and exhaust stack. This project reduces both the radionuclide content of the effluent and the amount of ammonia entering the main ventilation exhaust filters.

- Improved Fire Protection

This project supplied independent detectors and $\$ 156,000$ "Light Water" foam addition systems for G Cell and $R$ Cell which contain the principal inventories of organic solvent.

This project will supply "Light Water" foam systems $\$ 475,000$ in process cells containing organic solvent, plus the organic solvent storage tank in the pipe and operating gallery, plus wet pipe sprinkler systems in other process and service areas in the 202-A Building.

- Third Purex Ventilation Filter

A third main filter, completed in July 1978, will be put on standby (backup) operation shortly after plant operation is resumed. Filter design will provide capability for the effluent from that filter to meet the concentration guides of DOEM 0524 Appendix, Annex A.

Improvements PTanned and Under Construction

Major improvements planned and under construction for FY 1977 to Fy 1979 are given in the following paragraphs. 
- New Criticality Alarm System

This project will provide new nuclear criticality

$\$ 287,000$ incident alarms in the Purex Plant which will meet the criteria of DOEM 0530, Nuclear Criticality Safety, 12-21-76. Completion is scheduled for May 1979, but they will not be activated until plant startup.

- Safeguards

These projects will provide the Purex Plant with $\$ 4,700,000$ television surveillance and alarms on critical doors, intrusion detectors, door contact alarms, vehicle monitors and a new exclusion area guardhouse, emergency power and upgraded perimeter lighting, fences and related features, and SNM computer terminal and improvements.

- Head-End Measurement

This project will upgrade the main accountability tank sampling system and the associated shielding.

- Fire Protection

This project provides for a sprinkler system in the $\$ 395,000$ main ventilation tunnel to protect the main filters, fire doors and dampers, cable vault detectors, fire protection screens for hoods and glovebox exhaust filters, and fire walls between transformer banks.

- Waste Transfer Piping

This project will provide two new encased lines to $\$ 490,000$ bypass the 241-AX-151 Diverter Station and route Purex low-heat waste to the 242-A EvaporatorCrystallizer system.

- Plutonium Oxide Facilities

New equipment will be installed in $\mathrm{N} \mathrm{Cell} \mathrm{in} \mathrm{the}$ $\$ 11,000,000$ 202-A Building which will be used to convert the 
plutonium nitrate product to plutonium dioxide product. All effluents will be recyceld within the Purex Plant.

- Gaseous Effluent Control Improvements

This project will upgrade the present main stack

$\$ 545,000$ sampling and maintaining system and add flow totalizing.

This prnjes,t. will ungrade the resord sampler and $\$ 225,000$ monitor sampling and add a new flow totalizing system on the Purex PR Room stack.

This project will provide high efficiency particu$\$ 400,000$ late air (HEPA) filtration for exhaust air from the white room of the $P \& O$ gallery and emergency shutdown of exhaust from the remainder of the P\&O gallery.

- Liquid Effluent Control Improvements

This project will add a sampling, monitoring and $\$ 560,000$ flow totalizing system to the Purex Plant ammonia scrubber waste effluent.

This project will add sampling, monitoring, flow $\$ 660,000$ totalizing and diversion capabilities to the Purex Plant chemical sewer line discharge.

This project will reduce or eliminate a substantial $\$ 200,000$ portion of the condensate discharged to cribs and utllize the condensate in acid absorbers.

This project will add sampling, monitoring and flow $\$ 475,000$ totalizing to the process condensate discharge.

This project will make improvements to the effluent $\$ 280,000$ discharge system of the UNH Storage Area, providing capability for reprocessing contaminated waste and discharging clean wastes. 


\section{II.3.2 Uranium Oxide Plant Facilities}

\section{II.3.2.1 General Description}

The Uranium Oxide Plant is located in the south central portion of the 200 West Area, approximately five miles west of the Purex Plant (Figure II.2). The plant consists of two main buildings with a number of ancillary buildings and supporting facilities as shown in Figure II.11. An aerial photograph of the Uranium Oxide Plant complex is given in Figure II. 12 .

One of the two principal buildings, 224-U Building, was part of the original Hanford construction in 1943-1944, but was never used for its intended purpose as a plutonium separations plant. The second major building, 224-UA Building, was later built to house the uranium nitrate calciners and related powder handling and loadout facilities.

The 272-U Building houses maintenance shops for both radioactive and nonradioactive equipment servicing and repair.

The 203-U Building contains the uranyl nitrate hexahydrate (UNH) receiving and storage tanks.

The 211-U Building provides a chemical tank farm for receipt, storage and disbursement of bulk process chemicals; it also contains the tanks for recovered nitric acid receipt and storage.

The 221-U and 271-U Buildings are the original separations canyon and office buildings from which certain services (e.g., compressed air) are supplied to the Uranium Oxide Plant. 


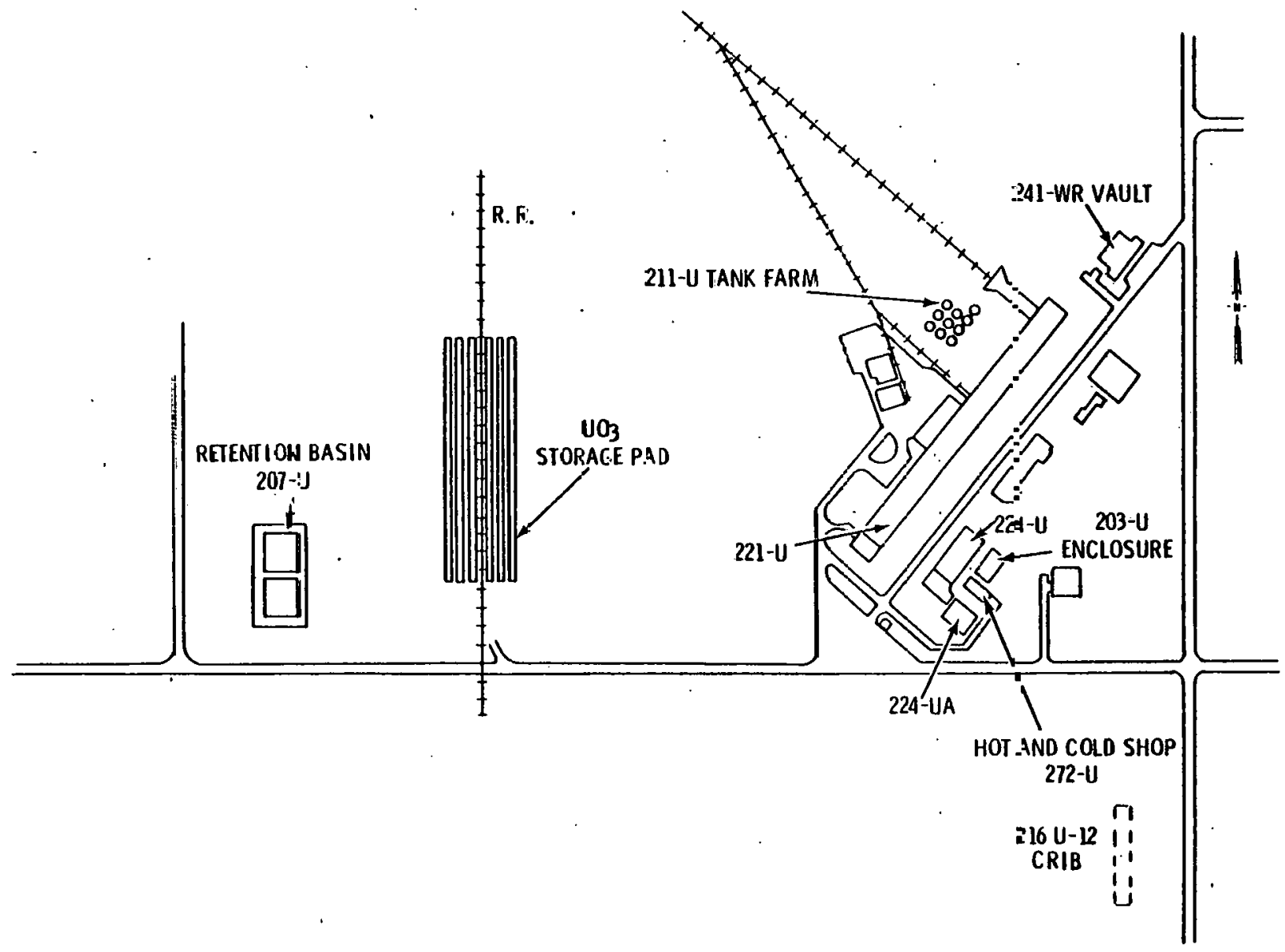

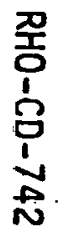

FIGURE II. 11

PLAN DIAGRAM OF THE URANIUM OXIDE PLANT COMPLEX 


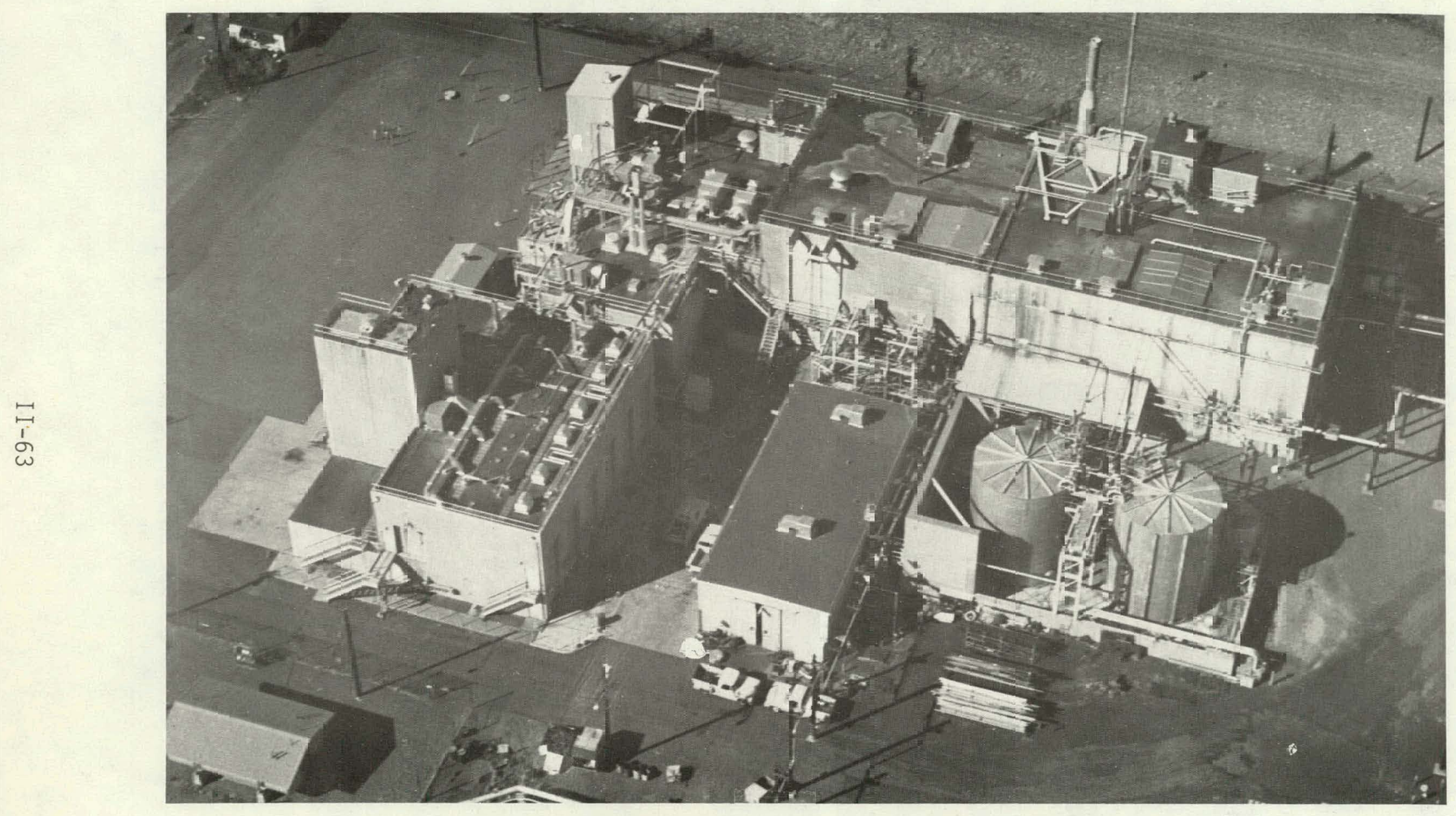

FIGLPE II. 2

UF:ANIUM OXIDE PLANT 
The 207-U Retention Basin is a facility for holdup of process cooling water to allow analysis before the water is discarded to a surface pond.

The 2727-W U0 $\mathrm{N}_{3}$ Storage Area is a series of fenced concrete pads on which containers of $\mathrm{UO}_{3}$ are stored awaiting offsite shipment.

The 224-U Building is 200 feet long, 60 feet wide and 40 feet high, with essentially all of the structure at grade level with the exception of $\mathrm{C} \mathrm{CC11,} \mathrm{which} \mathrm{has} \mathrm{a} \mathrm{deep} \mathrm{portion} 19$ feet below the yeneral cell base leve1. It is a combination of concrete block construction (offices, service areas, operating control room) and a 12-inch-thick poured concrete structure containing the six processing cells in which UNH concentration and acid recovery operations are conducted.

The cells and their functions are:

- A Cell - nitric acid recovery

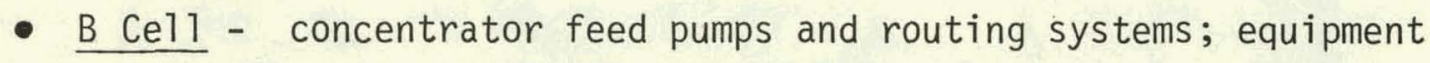
decontamination facilities

- $\underline{C}$ Cell - recovered acid receiving and distribution; waste UNH evaporator; process condensate collection

- $\underline{D}$ Cell - UNH concentration (from 60 weight percent to 100 weight percent)

- E and F Cells - not normally used

- Luckey Pot Room - batch (pot) calcination area, no longer used.

The occupied portion of the 224-U Building is a three-level arrangement with offices, ventilation and electrical equipment, and change rooms on the ground floor level; electrical switch gear, chemical makeup tanks, utility supply piping, and incoming power lines on the second floor; chemical addition tanks and process operations control centers for both 224-U and 224-UA Buildings on the third floor. 
The 224-UA Building is a concrete and sheet steel structure, 28 feet high, 70 feet long and 65 feet wide, holding the six calciners in individual bays with rollup steel doors. It has a five-story annex 53 feet high containing the powder handling equipment in the upper levels and the powder loadout and weighing facilities in the lower two levels. Figure 11.13 shows a plan view at ground level.

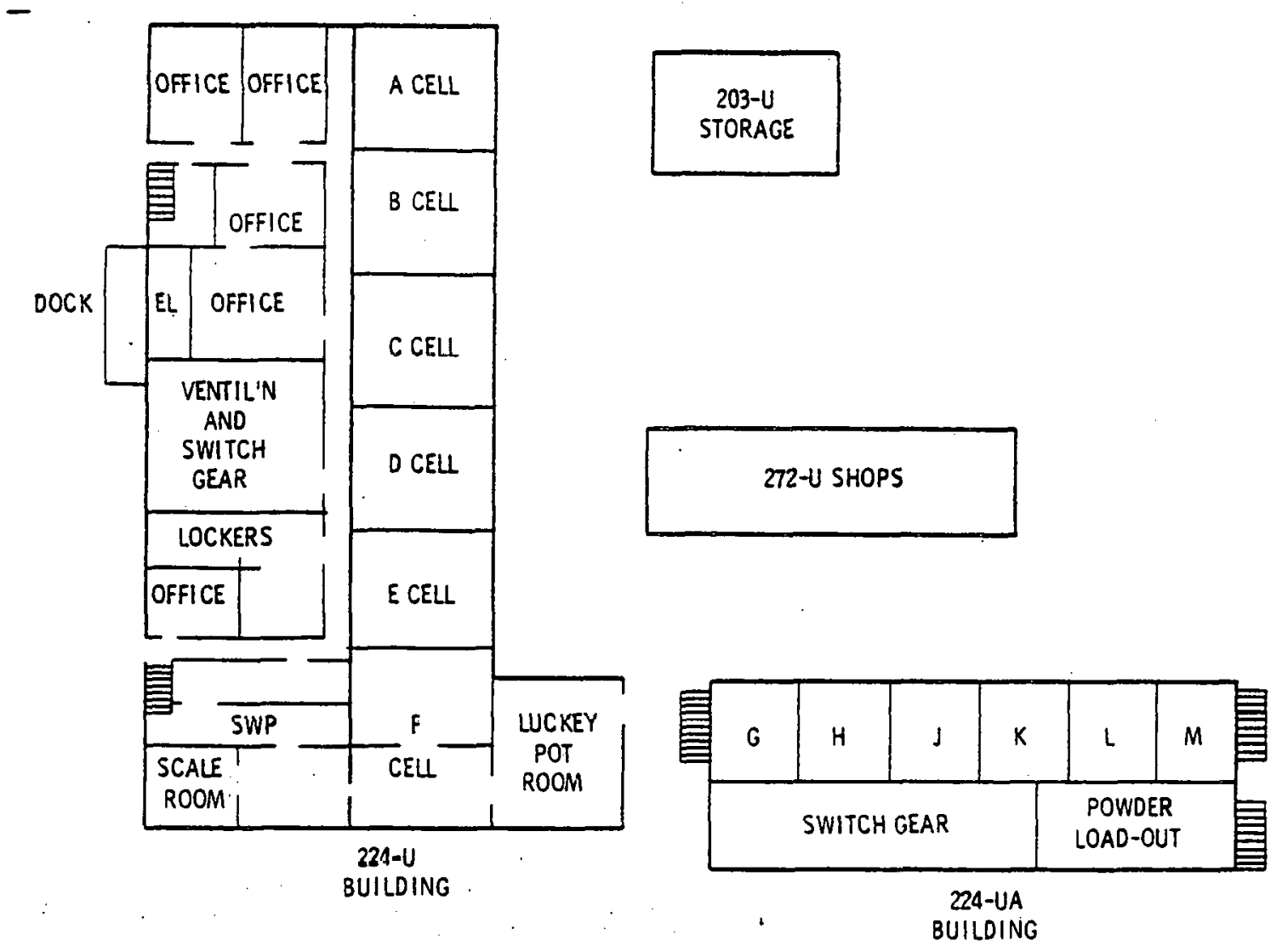

FIGURE II.13

PLAN VIEW OF TAE GRANTUM OXIDE PLANT AT GROUND LEVEL 


\section{II.3.2.2 Operational Programs}

The function of the Uranium Oxide Plant is to convert uranium nitrate solution received from the Purex Plant to solid $\mathrm{UO}_{3}$.

\section{II.3.2.3 Operational Systems}

The uranium product from the Purex Plant is an aqueous solution of approximately 60 weight percent UNH. This material is sufficiently free of both radioactive and nonradioactive contaminants to require no further purification before concentration and calcination. The 60 percent aqueous solution is concentrated to approximately 100 weight percent UNH, which is then fed into the continuous calciners where it is converted to $\mathrm{UO}_{3}$ powder. This is the Hanford final uranium product that is loaded into containers for offsite shipment to another DOE installation.

A schematic flow diagram of the uranium oxide process is given in Figure II.14.

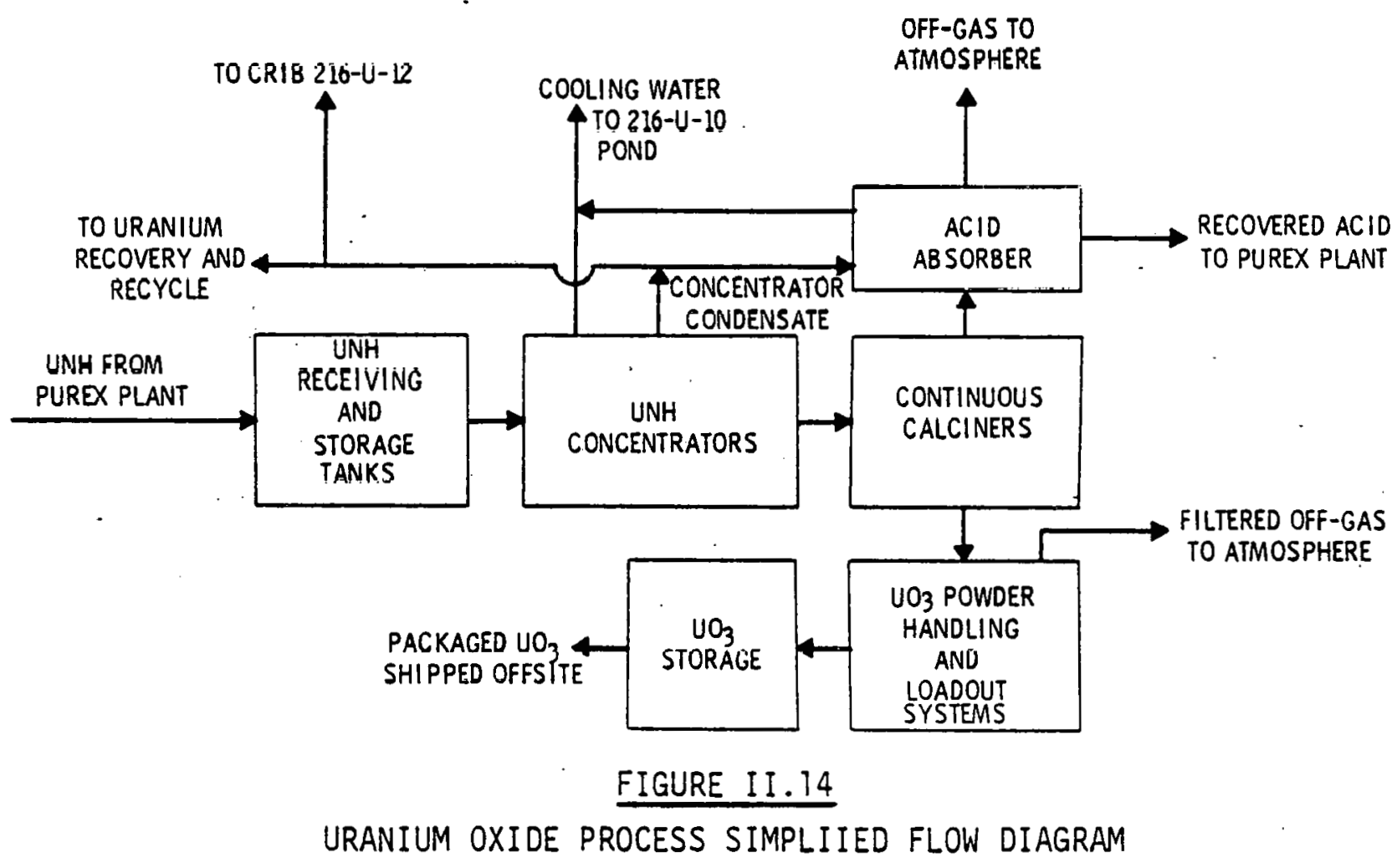




\section{Feed Receipt and Storage}

The Uranium Oxide Plant process starts with the receipt of UNH solution from the Purex Plant into the C-l Tank, where it is sampled for nuclear material accountability and examined for the presence of a separate organic solvent phase.

Any such two-phase systems are returned to the Purex Plant for removal of the organic solvent; this precautionary measure is to prevent the formation of potentially hazardous red oil during the following concentration step.

The solution, 60 percent UNH by weight, is moved into one of two 100,000-galion storage tanks from which it is pumped to one or more of three concentrators in D Cell. A "heel" of liquid 16 inches deep is maintained in the storage tanks to prevent organic solvent from reaching the concentrators in case any organic solvent gets past the $\mathrm{C}-1$ Tank inspection step.

\section{Uranyl Nitrate Hexahydrate Concentration}

The UNH solution is concentrated in thermosiphon evaporators from $480 \mathrm{~g}$ of uranium per liter to approximate $7 y \quad 1,200 \mathrm{~g}$ of uranium per liter, or 100 weight percent UNH... The overhead vapors are collected, condensed, analyzed and discarded to crib, or they are diverted to the C-2 Waste concentrator or to the 100 percent UNH storage tanks depending on their uranium content. A portion of this condensate is used for nitric acid absorber water.

The concentrated product solution flows by gravity from the concentrator to the $X-19$. Tank and/or the $X-30$ Tank from which it is then fed to the calciners. Because product $\mathrm{UO}_{3}$ specifications require 3,000 parts of sulfur per million parts of uranium, sulfuric acid is automatically metered into the $x-19$ and $X-30$ Tanks, based on the rates of UNH feed flow. 


\section{Calcination}

The calciners are horizontal troughs with horizontal multiblade agitators and are heated externally with electrical resistance heaters (see Figure II.15). They are operated with continuous solution feed and continuous powder draw-off via a weir that maintains a constant volume of powder in the trough. The process consists of converting UNH solution into $\mathrm{UO}_{3}$ by addition of external heat. As the UNH is decomposed by the heat, oxides of nitrogen and water are driven off and are drawn through the vent piping to the TA-3 Acid Recovery Tower where they are converted to nitric acid.

The oxide is formed in the calciner trough at a temperature of approximately $520^{\circ} \mathrm{F}$. The agitator in the trough keeps the oxide bed powder temperature uniform. The feed solution is pumped into the calciner under pressure of 80 to 110 psi through feed points that are beneath the surface of the powder bed. The $\mathrm{NO}_{3}$, as it is formed, overflows the weir in the calciner and flows to a pickup bin from which it is transferred to the powder handling system.

\section{Powder Haridling}

The $\mathrm{UO}_{3}$ powder is collected from the calciners in the ground-level pickup bins and is moved into the powder handiing system by pneumatic transfer under the partial vacuum created by the primary exhausters. The powder is moved by air to the fourth floor of the UA. Tower to the cyclone separator. . From there it flows by gravity through a hammermill (not normally used) on the third floor of the tower, then to a storage hopper on the second floor, and is unloaded from the hopper into containers in the UA Loadout Room on the first floor. The air leaving the cyclone separator flows through two sets of filter bags in series, then through a glass fiber filter and out to the atmosphere. The fine accumulated powder is periodically dislodged from the filter bags by compressed-air blow rings and drops into the hopper below. 


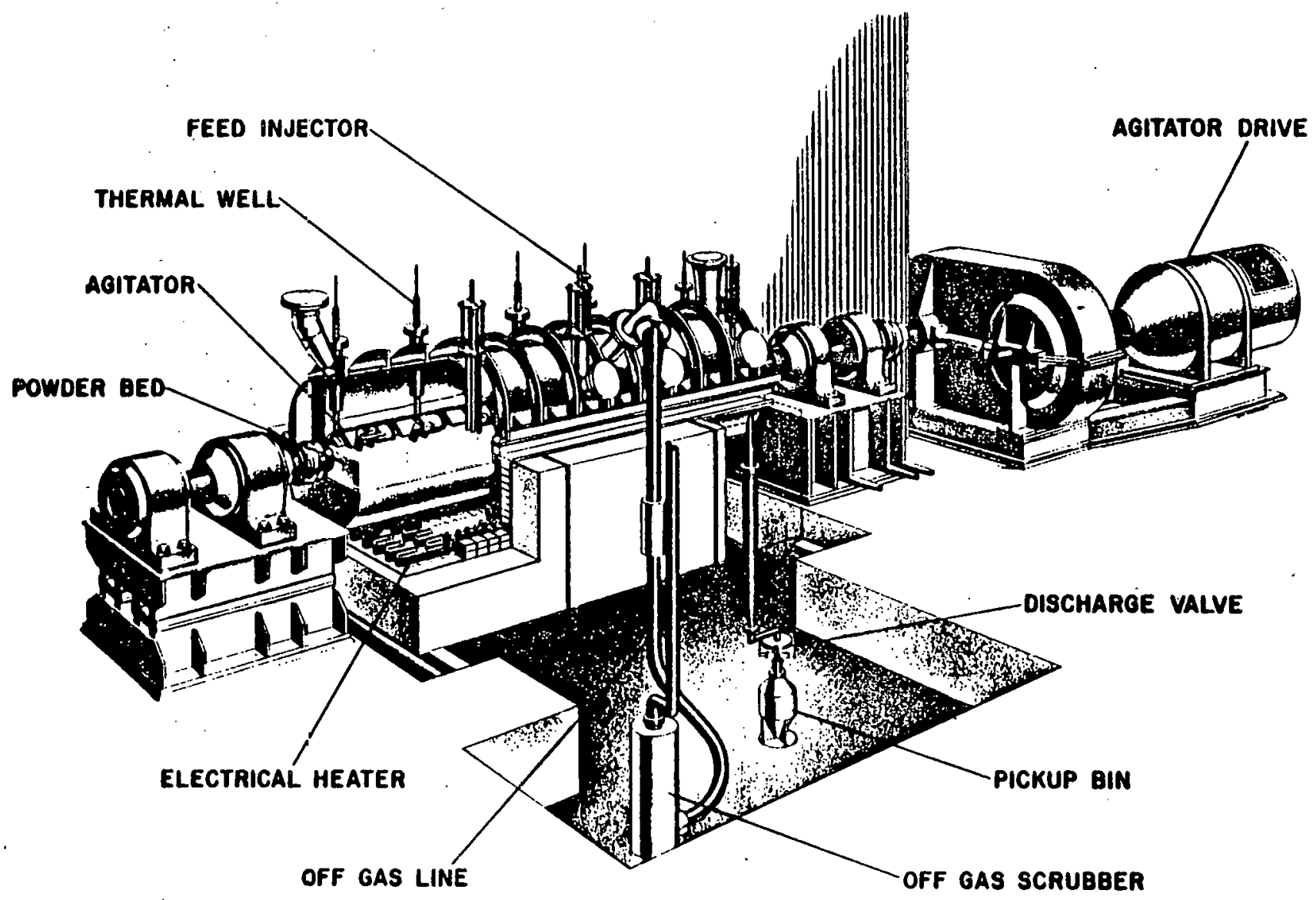

\section{FIGURE II. 15}

URANIUM NITRATE CALCINER 
Flow (air travel) is from the pickup bins through the powder discharge line to the cyclone separator, then to the primary filter bags, to the primary exhausters, from the discharge of the exhausters to the secondary filter bags, to the dry filter and out the secondary exhauster to the atmosphere.

The unmilled $\mathrm{UO}_{3}$ powder is produced in the form of small spherical pellets, averaging 0.1 to 0.2 millimeter in diameter. It is loaded into 55-gallon drums that meet Department of Transportation requirements* for strong, tightly. sealed, sound containers for the transport of "low spersifir artivity material". The pallet.s rontaining four drums are placed on the rack, loaded, sealed, weighed, banded with a nylon belt and moved to storage to await transfer to another DOE site. The use of "hopper" shipping containers is under review.

\section{Acid Recovery}

As the $\mathrm{UNH}$ is converted in the calciners to $\mathrm{UO}_{3}$ powder, large amounts of water vapor and gaseous nitrogen oxides are given off. These vapors are carried from the calciners through a fume vent line via wet scrubbers to the nitric acid recovery system.

The system consists of calciner off-gas wet scrubbers that remove fine particles of. entrained $\mathrm{UO}_{3}$, a vapor cooler, an absorber tower and a system of reflux water addition. The cooled gas passes into the Acid Absorber, TA-3, where the oxides of nitrogen are converted to nitric acid by reaction with oxygen and absorption in water. The acid, at approximately 50 weight percent concentration, is collected in the C-4 Tank and is pumped to the 211-U Tank Farm near the 271-U Building for storage and return to the Purex Plant. Net acid recovery is about 92 percent of that represented by the incoming uranyl nitrate solution.

The acid absorber vent flow with six calciners in operation is approximately $3,600 \mathrm{cfm}$. The absorber tower is vented to the atmosphere

\footnotetext{
*See Title 49 Code of Federal Regulations, Chapter I, Section 178.118.
} 
via the 80-foot-tall ventilation stack on the high portion of the 224-U Building roof. The stack release point is 120 feet above ground level. The radionuclide content of this discharge is well below.DOEM 0524 Appendix, Annex A, values for uncontrolled areas.

\section{Waste Uranium Recovery}

Uranium solutions and solids that escape from the process equipment are retrieved and returned for decontamination and salvage. The C-2 Tank is an evaporator used to collect floor flushings, equipment flushes, dissolved scrap powder, leachings from used powder bags, dust from used dry filters, etc. As the concentration of the solution reaches $480 \mathrm{~g}$ of uranium per liter in the C-2 Tank, the contents are pumped through a diatomaceous earth (Filter-Aid) filter and transferred to the X-38 Tank for storage and subsequent return to the Purex Plant for cleanup and recovery.

Waste Handling

Process condensates are collected in the C-5 Tank and are transferred to the 216-U-12 Crib. The condensate is pumped out on a batch basis and is automatically sampled. A composite sample of the liquid collected in the sample receiver is taken for laboratory analys is once a week. No neutralization is needed for this waste.

Cooling water and steam condensates flow to the 207-U Retention Basin and then to the 216-U-10 Pond. Sampling is the same as for process condensates. Both of these wastes are very low in radionuclide content.

\section{II.3.2.4 Water Use, Services and Utilities}

\section{Water}

Raw water is supplied to the Uranium Oxide Plant directly from the 3-million-gallon 282-W Water Reservoir Building near the 284-W Powerhouse, 
and also by a line extending from the Redox Plant main water line. This water is used as cooling water in the process condensers, the Acid Absorber (TA-3) Tower and the A-4 Gas Cooler; reflux water in the absorber tower if needed to supplement the process condensate; deluge water for the three UNH concentrators in $\mathrm{D}$ Cell; and other miscellaneous services. Average use during normal plant operations is $250 \mathrm{gpm}$.

Sanitary water is supplied from the 283-W Water Treatment Building for safety showers, drinking fountains, toilets and fire hydrants. Average demand for sanitary water during normal plant operations is $50 \mathrm{gpm}$.

Pumping facilities for both raw and sanitary water systems sound alarms in the 284-W Powerhouse (which is continually manned) in the event of abnormally low water pressure conditions.

\section{Electric Power}

Electric power sufficient to operate all the equipment in the 224-U Building is supplied from the 13.8-kV line through a 750-kVA transformer in the 252-U Substation approximately 250 feet west of the building. There is also an emergency powerline coming inlu lie 224-U Building through a 300-kVA transformer. This oriqinates in the 284-W Powerhouse from a $750-\mathrm{kW}, 2,300-\mathrm{V}$ steam turbine-operated generator that starts automatically if the main incoming power is lost.

The electrical power for the 224-UA Building is supplied through two 1,500-kVA transformers immediately south of the 224-UA Building. The system is designed so that eithor side will carry the load through an automatic bus tie that switches power from the remaining incoming line to pick. up the load.

There are three main switchgear rooms in the 224-U and 224-UA building, of which 224-UA Building is the largest and most complex, with its transformers needed for the calciner furnaces. There are 54 transformers 
serving the heating elements in the calciners plus regulators for these circuits needed for precise control of the electrical current to obtain the required calciner heating patterns. The calciner agitator switch gear is also in 224-UA Building; each switch gear carries $440 \mathrm{~V}$ and furnishes power to the 125-horsepower motors.

Emergency batteries are in place to maintain emergency lighting and minimal required ventilation.

Compressed Air

Compressed air at a pressure of 90 psi is supplied to the 224-U Building from the compressors located in the 271-U Building. The air is filtered in the 271-U Building and reduced to a pressure of 55 psi in the 224-UA Building. Here it is used to keep the $\mathrm{UO}_{3}$ powder out of the calciner agitator shaft packing glands and to clear the calciner feed points after process shutdown.

Instrument air is supplied at a pressure of 90 to $95 \mathrm{psi}$ from the main air supply through a separate line. It is dried in the 271-U Building and passed through charcoal filters in the 224-U Building.

The breathing air system has a separate air pump and storage tank that meet Mine Safety Appliance specifications. The system operates at 25 to $35 \mathrm{psi}$. The principal uses for fresh air masks are to protect personnel in areas containing uranium oxide dust or near welding being done in potentially contaminated areas.

An emergency diesel engine-driven compressor is interlocked with the air supply system and supplies $600 \mathrm{cfm}$ if the system pressure drops to 15 psi.

Steam

Steam is delivered from the 284-W Powerhouse as superheated steam at a pressure of 225 psi through a takeoff line from the main line that 
serves the Redox Plant. There is also a second line from the powerhouse that joins the Redox line south of the 224-U Building, and from which steam can be furnished to the 224-U Area if required.

Steam is used at several different pressures in the plant, ranging from $225 \mathrm{psi}$ for the vacuum jets, to $125 \mathrm{psi}$ for the UNH concentrators (which operate 24 hours per day during maximum capacity operating conditions), to 15 psi used primarily as a heating agent to prevent solutions from freezing in tanks with jackets and in jacketed feed lines and calciner feed points. During normal operations, total steam use averages about 10,000 pounds per hour.

\section{Fire Protection Systems}

The Uranium 0xide Plant is served by three fire hydrants, two on the sanitary water line and one on the raw water line. The nearest is about 85 feet from the 224-UA Building and has a capacity of 3,750 gpm. Water supplies are more than adequate to meet any foreseeable need.

The various buildings of the plant complex are not equipped with automatic fire extinguishing equipment, but hoses and manual fire extinguishers are available. The 224-UA Building and some of the auxiliary buildings (e.g., that for compressed gas storage and the paint shopl are covered by fixed-temperature automatic fire detection systems, with alarms in the buildings and in the 200 Area central fire station.

\section{II.3.2.5 Radioactive Effluents and Solid Waste}

Slightly radioactive liquid, gaseous and solid wastes are produced in the operation of the Uranium Oxide Plant, but the amounts produced and the levels of radionuclide concentrations are very low compared with those from the Purex Plant. Miscellaneous uranium solutions from sumps, floor drains, spilled and redissolved $\mathrm{UO}_{3}$ powder, leached bag filters, etc., are collected, filtered, concentrated and returned to 
the Purex Plant for reprocessing and uranium recovery. Process condensates are discharged to underground cribs; cooling water and steam condensates are discharged to surface ponds. Gaseous waste from concentration, calcining and acid recovery operations is discharged to the atmosphere. Approximately 92 percent of the oxides of nitrogen from the calcining off-gas are recovered as nitric acid which is sent to the Purex Plant for reuse. Solid waste is packaged and buried.

\section{Liquid Effluents}

The largest volume of liquid waste from the process is 120 million gallons of cooling water annually, plus steam condensate from the acid recovery and uranium nitrate concentration steps, plus chemical sewer waste. Total radionuclide content of this water in 1972 was less than $2 \mathrm{Ci}$ of combined fission products and alpha-emitting nuclides. This stream is sampled and analyzed; if it meets DOEM 0524 Appendix. Annex A, Table II guides for radionuclide content for uncontrolled areas, it is sent to the 216-U-10 Pond. See Section II.3.2.7 for additional sampling information. If $i$ ts radionuclide content exceeds this guideline concentration due to abnormal operation or an accident, it is sent to the 216-U-12 Crib.

Process condensate, largely from the UNH concentrators in the 224-U Building, averages about one million gallons annually, containing about $0.01 \mathrm{Ci}$ of total radionuclides. It is sampled and sent to the 216-U-12 Crib. Aqueous effluents from the Uranium 0xide Plant are a11 less than DOEM 0524 Appendix, Annex A concentration values.

\section{Gaseous Effluents}

Approximately $1.2 \times 10^{9} \mathrm{ft}^{3}$ of gases are discharged to the atmosphere from the Uranium Oxide Plant annually, containing an average (total) of $6 \times 10^{-3} \mathrm{Ci}$ of fission products and $9 \times 10^{-5} \mathrm{Ci}$ of alphaemitting radionuclides. The radionuclides are essentially a $11{ }^{106} \mathrm{Ru}$ and 
uranium, respectively. The concentrations discharged meet the guides of DOEM 0524 Appendix, Annex A.

The 224-U Building ventilation air supply is about 40,000 cfm. This incoming air stream is routed to A, B, C and D Process Cells and to the nonradioactive zones of the building. The air flowing into the cells is then exhausted unfiltered to the atmosphere by four roof fans. each having a capacity of 4,000 cfm. The flow of air is controlled by maintaining static pressure slightly above atmospheric pressure in the occupied areas and under a slight vacuum in the process reils. The remainder of the $40,000 \mathrm{ft}^{3}$ of air is exhausted through roof fans from the transformer/switch gear room and from the Luckey Pot room with no further treatment or filtration.

The 224-UA Building is supplied by a blower unit with a capacity of $36,000 \mathrm{cfm}$. The air is fed to all parts of the building and is exhausted unfiltered by roof vent fans. High efficiency particulate air filters will be added to the ventilation exhaust system vented directly to the a tmosphere. Six of the roof vent fans have a 4,900-cfm capacity and are located on the roof above the calciner cells, drawing air from the ceilings of all six cells. The seventh fan exhausts the air from the UA Tower at 3,000 cfm. The direction of flow is maintained by having the nonradioactive zone slightly pressurized. This prevents contamination of the radionuclide-free areas of the building. Above the second level, al1 the floors in the five-story UA Tower are made of grating which allows a free flow. of air up. the entire tower to the top floor from which the air is exhausted to the atmosphere through a two-stage glass fiber filter.

Process effluents from the UNH concentrators, concentrated feed receiver tanks and all C Cell vessels, are vented via steam jet through the D-3 Condenser and to the atmosphere through the 80-foot-tall stack on the roof of the 224-U Building. The TA-3 Acid Recovery Unit and the six calciners (through TA-3) are also vented to the atmosphere through this same stack; total effluent flow from this release point is about 
$3,600 \mathrm{cfm}$. The two $\mathrm{UO}_{3}$ powder handling systems operate under partial vacuum provided by the primary exhausters. Each system has its own glass fiber filters, bag filters and primary exhauster. However, they share a common secondary exhauster and vent stack which is located on the lower 224-UA Building roof. The stack is approximately 16 inches square and 11 feet tal1. The point of exhaust discharge is about 40 feet above ground level. The rate of air flow is 1,000 to $1,100 \mathrm{cfm}$. Effluents are sampled by an inventory method, with sampiing time intervals determined by the specific location and the potential for air contamination in that part of the process operations area.

Solid Waste

Radioactive solid waste is composed principally of items such as failed equipment, pipe, contaminated materials of construction and rags. About 700 to $800 \mathrm{ft}^{3} / \mathrm{yr}$ (total) is generated in a normal year of operation. This represents approximately $0.5 \mathrm{Ci}$ of total beta emitters; $0.03 \mathrm{Ci}$ of combined ${ }^{90} \mathrm{Sr},{ }^{137} \mathrm{Cs}$ and ${ }^{106} \mathrm{Ru}$ nuclides; and less than $1 \mathrm{~kg}$ of total uranium. This waste is buried in the 200 West Area industrial burial ground.

\section{II.3.2.6 Nonradioactive Effluents and Solid Waste \\ Sanitary Waste}

Waste from toilets, fountains, showers, etc., is discharged via the sanitary sewer system to a septic tank-tile field that also serves the 271-U Building.

Chemical Waste

Chemical waste consists mainly of water from floor drains, compressor coolers, etc. It can contain small amounts of nitric or sulfuric acids. It is proportionately sampled and periodically analyzed. It is discharged to the $216-U-10$ pond. 
Solid Waste

Nonradioactive solid waste is ordinary trash, primarily paper. It is compacted to approximately one-third volume and buried in the Hanford Reservation central sanitary landfill. The Uranium Oxide Plant output is negligible in comparison with the $360,000 \mathrm{ft}^{3} / \mathrm{yr}$ total for all of the Hanford Reservation.

\section{II.3.2.7 Effluent and Process Monitoring}

The functions of the instrument and radiological protection systems are to control process operations, to protect working personnel and the public against accidental exposure to the radionuclides and product materlais, and to verity proper tunctioning of the process and the safety systems in plant operations.

\section{Effluent Monitors}

Liquid effluentș (excluding sanitary waste) are process condensates, stcam condensates, cooling water and chemical sewer waste. Prucuss condensates and sump waste containing small amounts of radionuclides are collected, sampled by proportional samplers for weekly analys is, and are then sent to the $216=U-12 \mathrm{Cr} \cdot \mathrm{ib}$. Sledill cundensates and cooling water are sent to the 207-U Retention Basin, sampled and analyzed (as above), and sent on to the 216-U-10 Pond if found to be below the release guides (Section II.3.2.5) in radioactive contaminant content on a 24-hour average basis. If they contain radionuclides above guide limits, they are transferred from the retention basin to the 216-U-12 Crib. Chemical sewer effiluent is not continuously monitored but is proportionately sampled and periodically analyzed. This stream flows to the 216-U-10 Pond.

Monitors for air and airborne particulates are placed at several locations throughout the facility based on the occupancy of the areas, the air flow patterns and anticipated presence of radionuclides, especially where $\mathrm{UO}_{3}$ dust may be encountered. The types of monitors used 
differ depending on location. Some draw a known volume of room air through a fixed filter medium for a predetermined period of time, following which the filter medium is removed and quantitatively checked for radionuclide content. Others remove a sidestream sample (inventory) of gaseous effluent, from a ventilation discharge stream, for example, and pass it through a filter in a similar manner for a similar check. Periodicity of the determination depends on location and degree of contamination expected.

There are no continuous or in-line effluent monitors in the Uranium oxide Plant that indicate or record in the operating control gallery.

Solid waste is monitored by appropriate portable instruments for contamination levels, packaged if required, and sent to the 200 West Area burial ground.

\section{Personne] Monitors}

Instruments and systems for monitoring radioactivity are located throughout the facilities. Bench-mounted monitors are provided for personal surveys as needed, and hand and foot monitors are installed near the exits from the change rooms and established radiation control zones. Portable instruments are used for measuring alpha, beta and gamma radiation in conjunction with counting techniques in the laboratory.

\section{Building Monitors}

Building monitors, mainly Beckman ionization chambers, are located at various points in the plant where the highest concentrations of radionuclides are anticipated. (Although the concentrations of contaminants such as ${ }^{95} \mathrm{Zr}-\mathrm{Nb},{ }^{106} \mathrm{Ru}$ and ${ }^{137} \mathrm{Cs}$ are extremely $10 \mathrm{w}$ in the Purex UNH solution as received, such fission products do accumulate slowly in process equipment during concentration and.calcination operations.) These monitors indicate and record in the third floor control room. In 
addition, there are portable instruments that are used at any point of interest not covered by a fixed monitor.

\section{Process Monitoring Instrumentation}

The Purex UNH product fed into the Uranium Oxide Plant is so well purified that it is less radioactive than naturally occurring uranium. This allows contact operations throughout the plant without exceeding occupational radiation exposure limits. However, most of the Uranium Oxide Plant process operations are controlled remoțely for reasons of convenience and operating economy.

Most of the process operations, including calcination and the powder handling systems of the 224-UA. Building, are controlled from the continuously manned third floor control room in the 224-U Building. Measurements essential to safe operation of the facility are displayed, recorded, controlled and alarmed in the control room. Measurements necessary for the normal operation of the plant, including some radiation measurements and principal operational parameters, are recorded and alarmed in the control room. Other measurements of noncritical parameters for operation of the facility are displayed on local instruments or alarmed in the control room.

Process specifications and operating limits have been established for all streams and points in the operations as required to ensure safe output of specification products. It is the function of the various instrument systems to correctly indicate and allow proper assessment by operating personnel of these operating conditions on a continuous basis. Therefore, a continuous program of instrument service, calibration and maintenance is part of the Uranium Oxide Plant operation. 


\section{II.3.2.8 Planned Modifications to Uranium Oxide Facilities}

Major improvements planned are given in the following paragraphs.

- $\mathrm{UO}_{3}$ Loadout Room Dust Control

This project will upgrade the $\mathrm{UO}_{3}$ loadout system $\$ 300,000$ to improve operability and to control $\mathrm{UO}_{3}$ powder contamination to operating areas and operating personnel.

- Gaseous Effluent Improvements - $\mathrm{UO}_{3}$

This project will provide high efficiency particu$\$ 630,000$ late air (HEPA) filtration capability for certain ventilation exhaust streams in the 224-UA Building. This project also improves their sampling and monitoring capability.

- $\mathrm{UO}_{3}$ Plant Liquid Effluent Measurement

Equipment will be provided for flow-rate measurements and totalizing; currently planned to be funded from capital equipment. 
1. T. J. Colven, Jr., G. M. Nichols, and T. H. Siddal, TNX Evaporator Incident, January 12, 1953, DP-25, E. I. Du Pont de Nemours and Company, Inc., Savannah River Laboratory, Augusta, Georgia, May $15,1953$.

2. R. M. Wagner, Investigation of Explosive Characteristics of Purex Solvent Decomposition Products (Red 0i1), HW-27492, General Electric Company, Richland, Washington, March 17, 1953. 


\section{ENVIRONMENTAL EFFECTS}

\section{III.1 PUREX PLANT}

III.1.1 Radiological Impacts

\section{III.1.1.1 General}

Radioactive materials are released to the environment by discharges to the atmosphere and to the ground as a result of the operation of the Purex and Uranium Oxide Plants. This section presents: (1) the estimates of types, sources and amounts of these releases anticipated with the resumption of Purex Plant operations; and (2) the calculated potential impacts of such releases.

Detailed studies have been conducted at Hanford to determine the exposure pathways leading to man from these sources. A complete discussion of these exposure pathways is presented in ERDA-1538, Section III.I.

Past studies, combined with results of the environmental surveillance program, have enabled scientists to develop the characteristics of a hypothetical person whose dietary and recreational habits maximize, through each separate pathway, the dose he might receive. Such a hypothetical person is called the "maximum individual". The habits and diet of the maximum individual comprise the maximum intake or exposure reported for each exposure pathway in spite of the fact that the maximum values are not, in actuality, attributable to the same person.

Maximum individual and population doses (generally presented as oneyear dose commitments) from Hanford operations are presented in ERDA-1538, Section III.1. The dose calculations in that statement are based upon the cumulative annual radioactive releases from all Hanford operations; doses from the operation of individual facilities are not separated from the total Hanford dose.

In this assessment, dose calculations are based on 50-year dose commitments and on the separate radioactive releases from the Purex and 
Uranium Oxide Plants. The location of the maximum individual, as in ERDA-1538, is directly across the Columbia River.from the Hanford 300 Area. The maximum possible dose to the maximum individual was calculated using computer codes described in ERDA-1538, Appendix III-B.

All significant exposure pathways were evaluated. They included submersion in the airborne effluent plume, consumption of drinking water and foodstuffs irrigated with Columbia River water, ingestion of radioactive iodine through the cow-to-milk pathway and consumption of fish. The methods used were expected to provide a best estimate of the doses associated with the different exposure pathways.

Section III.1.2 of ERDA-1538 discusses the impact of radionuclide releases at Hanford on biota other than man. The discussion includes a summary of research and surveillance programs designed to assess the possible changes in Hanford terrestrial and aquatic environment since operations began in 1944 .

\section{III.1.1.2 Effluent Releases}

\section{Liquid Effluents}

The radioactive liquids (not including high-level radioactive wastes, management of which is discussed in ERDA-1538) released to the environment (cribs and ponds) in 1972, the latest year of Purex plant operation, are summarized in Tables III. 1 and III.2. These tables also

- show the estimated maximum annual releases from future normal operations. These releases are based on the assumption that 1,000 metric tons wi11 be about the maximum throughput in any future year. Changes in process flowsheet and improved radionuclide controls, (see Section II.3.1.8) since the 1972 operation and shutdown have been used in the estimates, but no future technological or operating imporvements beyond those now planned, have been considered. Releases from 1973 through 1979 are not show, since 


\section{TABLE . III.1}

ACTUAL AND ESTIMATED ANNUAL LIQUID WASTE DISCHARGES TO CRIBS FROM THE PUREX PLANT(a)

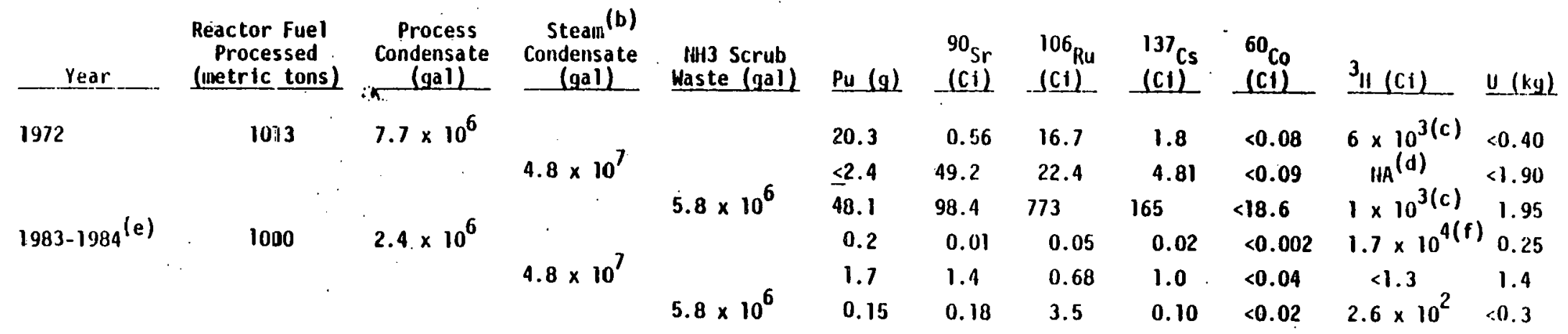

(a) Numbers designated as "less than" (s) are, or are derived from, values of the lower Iinits of detectlon.

(b) Radionuclide releases shown represent rout ine releases only. Equipment and coil failure could result in higher values.

(c) Calculated from previous sample results.

(d) NA, not analyzed. $_{\text {. }}$

(e) Although startup could be delayed, these values represent the probable annual maxinumi through $N$ Reactor shutdown in 1990. Annual anounts will probably decrease in future years as the accumulated fuel inventory is reprocessed.

(f) Estlulates slightly higher than 1972 data based on slightly higher exposure rates and process flowsheet varlatlons.

\section{TABLE III.2}

ACTUAL AND ESTIMATED ANNUAL LIQUID WASTE DISCHARGES TO P.ONDS FROM THE PUREX PLANT(a)

\begin{tabular}{|c|c|c|c|c|c|c|c|c|c|c|}
\hline Year & $\begin{array}{l}\text { Reactor Fuel } \\
\text { Processed } \\
\text { (metric tons) }\end{array}$ & $\begin{array}{c}\text { Cooling } \\
\text { Water (gal) }\end{array}$ & $\begin{array}{c}\text { Chemfcal } \\
\text { Sewer (gal) }\end{array}$ & Pu (g) & $\begin{array}{l}90_{\mathrm{Sr}} \\
(\mathrm{CI})\end{array}$ & $\begin{array}{r}106 \\
(\mathrm{Ru}) \\
\end{array}$ & $\begin{array}{l}{ }^{137} \mathrm{Cs} \\
(\mathrm{Cl})\end{array}$ & $\begin{array}{l}{ }^{60} \mathrm{Co} \\
\text { (Ci) }\end{array}$ & ${ }^{3} H(C 1)$ & $\underline{U}(\mathrm{~kg})$ \\
\hline \multirow[t]{2}{*}{1972} & 1013 & $2.6 \times 10^{9}$ & & $<5.1$ & $<0.3$ & $<4.8$ & $<1.5$ & $<1.0$ & ${ }_{I I A}^{(b)}$ & $<55$ \\
\hline & & & $6.3 \times 10^{7}$ & $<2.0$ & $<0.02$ & $<0.14$ & 0.33 & $<0.03$ & NA & $<4$ \\
\hline \multirow[t]{2}{*}{$1983-1984^{(c)}$} & 1000 & $1.1 \times 10^{9}$ & & $<2.0$ & $<0.1$ & $<2.0$ & 0.6 & $<0.4$ & $<21$ & $<22$ \\
\hline & & 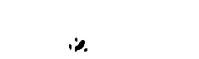 & $2.4 \times 10^{8}$ & $<0.1$ & $<0.01$ & $<0.01$ & $<0.01$ & $<0.01$ & $<5$ & $<9$ \\
\hline
\end{tabular}

(a) Wumbers designated as "less than" $(<)$ are, or are derived from, values of the detection 1 imits.

(b) NA, not analyzed.

(c) Al though startup could be delayed, these values represent the probable annual maximuan through N Reactor' shutdown In 1990 . Annual amounts will probably decrease in future years as the accumulated fucl inventory is reprocessed. 
the plant was not operated (i.e., no fuels were reprocessed) and the only releases were (and would be) minor amounts principally associated with shutdown, standby and startup activities.

\section{Gaseous Effluents}

The radionuclides released to the atmosphere in the gaseous effluents from the Purex Plant in calendar year 1972 are summarized in Table III.3. This table also shows the estimated annual maximum releases for subsequent years as noted for Liquid Efflucnts, above.

Releases from 1973 through 1979 are not shown since the plant was not operated (i.e., no fuels were reprocessed) and releases were (and would be) minor and principally associated with shutdown, standby and startup activities.

Estimated individual and population doses resulting from the gaseous releases from the Purex Plant estimated in Table III.3, are given in Tables III.4 and III.5 for 1972 and in Tables III.6 and III.7 for future annual maximum operations.

\section{III.1.1.3 Solid Waste}

In 1972 approximately $16,000 \mathrm{ft}^{3}$ of industrial and mixed fission product wastes from the Purex Plant were buried in the 200 Area burial grounds. These wastes contained approximately $31,000 \mathrm{Ci}$ of gross beta emitters; $2,500 \mathrm{Ci}$ of combined ${ }^{90} \mathrm{Sr},{ }^{106} \mathrm{Ru}$ and ${ }^{137} \mathrm{Cs}$; and less than $0.1 \mathrm{~g}$ of total plutonium. In addition, approximately $6,7.00 \mathrm{ft}^{3}$ of transuranic waste containing $43 \mathrm{~g}$ of plutonium and about $180 \mathrm{Ci}$ of total beta, ${ }^{90} \mathrm{Sr},{ }^{106} \mathrm{Ru}$ and ${ }^{137} \mathrm{Cs}$ combined, were put into 20 -year retrievable storage. 


\section{TABLE III.3}

ACTUAL AND ESTIMATED ANNUAL GASEOUS RELEASES FROM THE PUREX PLANT (a)

\begin{tabular}{|c|c|c|c|c|c|c|c|c|c|}
\hline Year & $\begin{array}{c}\text { Volume } \\
\text { from } 291-A \\
\text { Stack }(\mathrm{ft})\end{array}$ & $\begin{array}{l}\text { Volume froin Short } \\
\text { Stacks and Roof } \\
\text { Vents (ft }{ }^{3} \text { ) }\end{array}$ & $\begin{array}{c}\text { Total } \\
\text { Alpha (b) } \\
\text { (C1) }\end{array}$ & $\begin{array}{l}\text { Totgl } \\
\text { Beta (b) } \\
\text { (c1) }\end{array}$ & $\begin{array}{l}{ }_{129}(\mathrm{c}) \\
(\mathrm{Cl})\end{array}$ & $\begin{array}{l}131 \\
(C 1)\end{array}$ & $\begin{array}{c}85_{\mathrm{Kr}}(\mathrm{c}) \\
(\mathrm{Cl}) \\
\end{array}$ & $\begin{array}{l}3_{H}(c) \\
(C 1)\end{array}$ & $\begin{array}{l}{ }^{14} c^{(c)} \\
(C i)\end{array}$ \\
\hline 1972 & $6.3 \times 10^{10}$ & $5.6 \times 10^{10}$ & $\begin{array}{l}3.0 \times 10^{-3} \\
1.3 \times 10^{-3}\end{array}$ & $\begin{array}{l}4.4 \times 10^{-1} \\
1.5 \times 10^{-1}\end{array}$ & $1.4 \times 10^{-1}$ & $2.1 \times 10^{-1}$ & $4.1 \times 10^{5}$ & $1 \times 10^{3}$ & $7 \times 10^{-1}$ \\
\hline $1983-1984^{(d)}$ & $7.1 \times 10^{10}$ & $5.6 \times 10^{10}$ & $\begin{array}{l}3.0 \times 10^{-3} \\
7.2 \times 10^{-5}\end{array}$ & $\begin{array}{l}4.0 \times 10^{-1} \\
5.5 \times 10^{-3}\end{array}$ & $1.7 \times 10^{-1}$ & $<1.0 \times 10^{-1}$ & $6.5 \times 10^{5}$ & $9 \times 10^{2}$ & $6.6 \times 10^{-1}$ \\
\hline
\end{tabular}

(a) Nunbers designated as "less than" $(<)$ are, or are derived fron, values of the lower limits of detection.

(b) As particulate material.

(c) Calculated values; gas streams were noz sampled and analyzed for these elements.

(d) Although startup could be delayed, these values represent the probable annual maxtmum through $N$ Reactor shutdown in 1990. Aniual aniounts will probably decrease in future years as the accuinulated fuel inventory is reprocessed.

\section{TABLE III.4}

ESTIMATED 50-YEAR MAXIMUM INDIVIDUAL DOSE COMMITMENT FROM THE ANNUAL EFFLUENT RELEASE FROM PUREX PLANT DURING THE 1972 PERIOD(a)

\begin{tabular}{|c|c|c|c|c|c|c|}
\hline & \multirow[b]{2}{*}{ Annual Exposure } & \multicolumn{5}{|c|}{ 50-Yr Dose Coumitiment (mrem) } \\
\hline & & Skin & Whole Body & GI-LLI(D) & Thyroid & Bone \\
\hline Alr Submersion & $8,766 \mathrm{hr}$ & $8 \times 10^{-2}$ & $8 \times 10^{-4}$ & $8 \times 10^{-4}$ & $8 \times 10^{-4}$ & $8 \times 10^{-4}$ \\
\hline Tritium (Inhalation and Transpiration) & $8,766 \mathrm{hr}$ & $1 \times 10^{-4}$ & $1 \times 10^{-4}$ & $1 \times 10^{-4}$ & $1 \times 10^{-4}$ & -- \\
\hline Radiolodine & & & & & & \\
\hline Inhalation & $7,300 \mathrm{~m}^{3}$ air & -- & - & -- & $3 \times 10^{-3}$ & -- \\
\hline Milk & 274 liters $^{(d)}$ & -- & -- & -- & $1 \times 10^{-1}$ & -- \\
\hline Vegetables & $30 \mathrm{~kg}(\mathrm{e})$ & -- & -- & -- & $2 \times 10^{-2}$ & -- \\
\hline 0ther Radionuclides (Inhalation) & $8,766 \mathrm{hr}$ & -- & $4 \times 10^{-3}$ & $3 \times 10^{-4}$ & $2 \times 10^{-4}$ & $\underline{3 \times 10^{-2}}$ \\
\hline Total & & $8 \times 10^{-2}$ & $5 \times 10^{-3}$ & $1 \times 10^{-3}$ & $1 \times 10^{-1}$ & $3 \times 10^{-2}$ \\
\hline
\end{tabular}

(a) Using releases tabulated in Table III.3.

(b) $5 I-L L I$, gastrointestinal-- lawer large intestine.

(c) Humbers in parentheses indizate internal dose from external exposure.

(d) One liter per day for a 9-month grazing period.

(e) Two hundred graws per day for 5 -month produce season. 


\section{TABLE III.5}

ESTIMATED 50-YEAR POPULATION DOSE COMMITMENT FROM THE ANNUAL EFFLUENT RELEASE FROM PUREX PLANT DURING THE 1972 PERIOD

Air Submersion

Tritium (Inhalation and Transpiration)

Radioiodine (Inhalation, Milk, Vegetables)

other Radionuclides (Inhalation)

Total

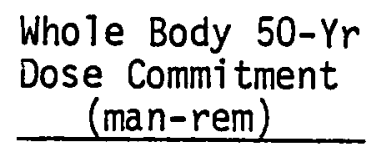

$7 \times 10^{-2}$

$1 \times 10^{-2}$
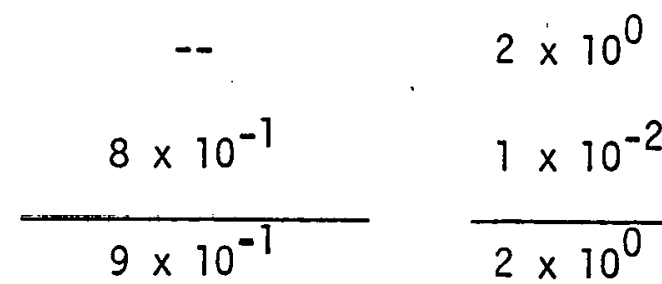

Thyroid $50-Y r$ Dose Commitment (man-rem)

$\left(7 \times 10^{-2}\right)(a)$

$1 \times 10^{-2}$

$2 \times 10^{0}$

$1 \times 10^{-2}$

$2 \times 10^{0}$

(a) Numbers in parentheses indicate internal dose from external exposure. 


\section{TABLE III.6}

ESTIMATED 50-YEAR MAXIMUM INDIVIDUAL DOSE COMMITMENT FROM THE ANNUAL MAXIMUM ROUTINE EFFLUENT RELEASE FROM FUTURE PUREX PLANT OPERATION(a)

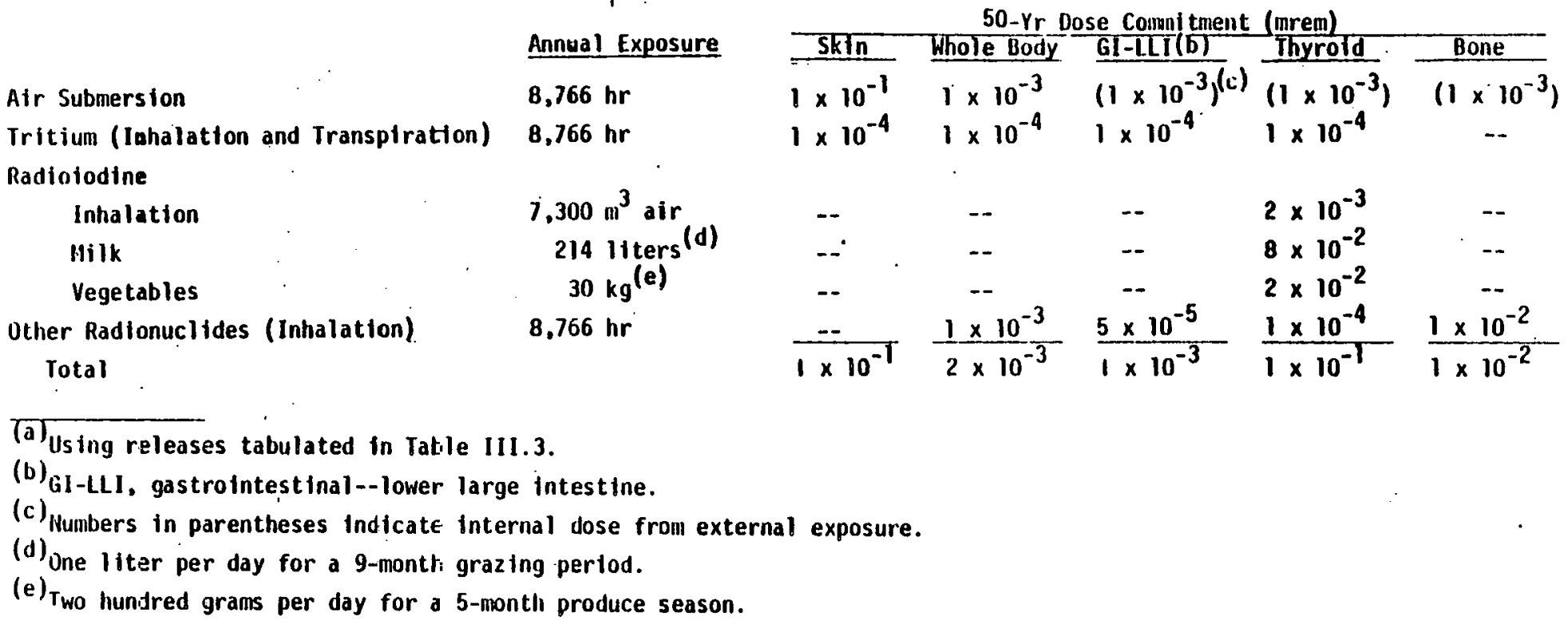

50-Yr Dose Comnitment (mrem)

Annual Exposure

Air Submersion

$8,766 \mathrm{hr}$

Tritium (Iahalation and Transpiration)

$8,766 \mathrm{hr}$

\begin{tabular}{|c|c|c|c|c|}
\hline SkIn & Whole Body & GI-LLI (D) & Thyrotd & Bone \\
\hline $1 \times 10^{-1}$ & $1 \times 10^{-3}$ & $\left(1 \times 10^{-3}\right)^{(c)}$ & $\left(1 \times 10^{-3}\right)$ & $\left(1 \times 10^{-3}\right)$ \\
\hline$\times 10^{-4}$ & $1 \times 10^{-4}$ & $1 \times 10^{-}$ & $1 \times 10^{-}$ & - \\
\hline
\end{tabular}
Radiolodine

\section{Inhalation}

lilk

Vegetables

Other Radionuclides (Inhalation). Total

Tajing releases tabulated in Tatile III.3.

(b) GI-LLI, gastrointestinal--lower large intestine.

(c) Mumbers in parentheses Indicate internal dose from external exposure.

(d) One liter per day for a 9-month grazing perlod.

(e) Two hundred grams per day for a 5 -montli produce season. 
Future Purex Plant operations will include efforts to reduce amounts of waste generated, and are expected to result in smaller annual releases than in 1972. (Amounts in years just prior to Purex startup may be somewhat higher than 1972 due to refurbishing activities in preparation for plant startüp.)

\section{TABLE III.7}

\section{ESTIMATED 50-YEAR POPULATION DOSE COMMITMENT FROM THE ANNUAL MAXIMUM ROUTINE EFFLUENT RELEASE FROM \\ FUTIIRF. PIIRFX PI.ANT OPERATION}

\begin{tabular}{|c|c|c|}
\hline . & $\begin{array}{l}\text { Whole Body } 50-Y r \\
\text { Dose Commitment } \\
\text { (man-rem) }\end{array}$ & $\begin{array}{c}\text { Thyroid } 50-Y r \\
\text { Dose Commitment } \\
\text { (man-rem) } \\
\end{array}$ \\
\hline Air Submersion & $1 \times 10^{-1}$ & $\left(1 \times 10^{-1}\right)^{(a)}$ \\
\hline $\begin{array}{l}\text { Tritium (Inhalation and } \\
\text { Transpiration) }\end{array}$ & $1 \times 10^{-2}$ & $1 \times 10^{-2}$ \\
\hline $\begin{array}{l}\text { Radioiodine (Inhalation, } \\
\text { Milk, Vegetables) }\end{array}$ & -- & $2 \times 10^{0}$. \\
\hline $\begin{array}{l}\text { Other Radionuclides } \\
\text { (Inhalation) }\end{array}$ & $1 \times 10^{-1}$ & $1 \times 10^{-2}$ \\
\hline Total & $2 \times 10^{-1}$ & $2 \times 10^{0}$ \\
\hline
\end{tabular}

\section{III.1.1.4 Occupational Doses to Employees}

The total complement of workers located at and directly innvolved in the Purex Plant when it is in full operation, is approximately 225, including operations, maintenance, laboratory, engineering support services, and supervision. In 1971 to 1972, the annual average total body occupational radiation dose of the Purex workers was approximately 0.58 rem; the maximum was $2.1 \mathrm{rem}$, and the minimum was $0.1 \mathrm{rem}$. (The DOE recommended limit is 5 rem per year. The working guide for Purex Plant employees and other 200 Area workers is 3 rem of gamma radiation per year.) 
In future operation, the Purex Plant will be operated in sequence with B Plant and the Uranium Oxide Plant; this will mean a full work force at Purex for about seven months of the year, and a standby force of only about 100 for the rest of the year. The anticipated result of the part-time operation plus the periodic personnel relocation will be a reduction in Purex $\mathrm{Plant-related} \mathrm{radiation} \mathrm{exposure} \mathrm{per} \mathrm{employee} \mathrm{to}$ about 60 to 70 percent of the 1971 to 1972 levels.

This exposure will be further reduced by continuation of the current radiological improvement program designed and operated to maintain radiation exposures at levels as low as reasonably achievable.

\section{III.1.1.5 Transportation of Radioactive Materials}

The plutonium and uranium product solutions from the Purex Plant during past operations have been routinely shipped by truck to the 200 West Area to $Z$ Plant and the Uranium Oxide Plant, respectively.

For onsite shipments of plutonium oxide and uranium product solution in the future, a Packaging and Shipping Safety Committee will ensure that all shipping containers meet the requirements of DOEM 0529, Safety Standards for Packaging of Fissile and Other Radioactive Materials. Procedures will detail the assembly, inspection, loading and unloading requirements of packages for radioactive material transport. The combination of container requirements, traffic controls, safeguards and other administrative control, will provide shipment safety equivalent to Department of Transportation (DOT) approved offsite shipments. (Subsequent offsite shipments of the product from the Uranium Oxide Plant are discussed in later sections.)

Up to the present, neptunium has been the only radioactive material shipped offsite directly from the Purex Plant since, as noted earlier, uranium and plutonium have been sent to the 200 West Area for further processing. Since plutonium oxide will be the Purex product in the future, however, this product may also be shipped offsite from the Purex Plant, depending on the receiver's requirements and product specifications. 
Neptunium nitrate will be stored in the Purex Plant. Shipments to the Savannah River Plant (SRP) in the future, will depend on program requirements. When it is sent to SRP, transport will be in DOT-approved containers by commercial carrier using the security package system in exclusiveuse trucks escorted by DOE couriers. Applicable regulations covering allowable radiation levels for such transport will ensure that the three to five shipments per year will represent essentially no radiation exposure for the general public during the 3,000-mile trip, and no exposure exceeding occupational limits for the transport workers.

\section{III.1.2 Nonradiological Impacts}

\section{III.1.2.1 Effluent Releases}

\section{Liquid Effluents}

Sanitary Waste. The Purex Plant, while operating sequentially with B Plant, will use sanitary water at an estimated rate of about $1.3 \times 10^{8} \mathrm{gal} / \mathrm{yr}$, compared with the rate of $1.8 \times 10^{8} \mathrm{gal} / \mathrm{yr}$ shown in ERDA-1538. Approximately 10 percent of this amount serves fountains, toilets, showers. sinks, lunchroom and other nonradiation zone outlets. This is discharged via the sanitary sewer system to a septic tank-tile field disposal area approximately 1,500 feet north of the 202-A Building. The rest of the sanitary water is, in general, discharged to underground cribs via the process and ammonia scrubber evaporator condensates and to a pond via the chemical sewer.

Industrial Waste: Waste released via the chemical sewer to the 216-B-3 Pond. contains small amounts of process chemicals from spills, floor flushes, discards in chemical preparations, etc., and from regeneration of the water demineralizers. In the past, some radionuclides have been generally present, as shown in Table III.2. However, condensate recycle (see section II.3.1.8) Wi17 leave the chemical sewer discharge virtually free of radionuclides. The principal chemicals discharged via the chemical 
sewer to the 216-B-3 Pond are listed in Table III.8 in pounds of 100 percent chemical per ton of uranium fuel reprocessed, based on a loss of one percent of the chemical used.

Other chemicals are occasionally lost or routed to the chemical sewer in minor amounts, for example, sulfuric acid from regeneration of the water demineralizers.

TABLE III.8

PRINCIPAL CHEMICALS RELEASED TO GROUND VIA PUREX PLANT CHEMICAL SEWER

Chemical

Ammonium Fluoride - Ammonium Nitrate

Potassium Hydroxide

Nitric Acid

Ferrous Sulfamate

Sulfamic Acid

Sugar (Sucrose)

Sodium Hydroxide

Sodium Carbonate

Aluminum Nitrate
Amount (1b) ${ }^{(a)}$

5.8

2.3

12.7

0.3

0.4

1.1

6.4

0.2

1.2

(a) Per ton of uranium processed assuming $1 \%$ chemical loss.

Cooling Water. Large volumes of raw water are used in various 200 Area chemical operations in cooling coils and condensers. This water, normally not contaminated with radionuclides, is used on a once-through basis and discarded to surface ponds in or near the 200 Areas. The two principal ponds serving the 200 East Area are Gable Mountain Pond (216-A-25) and B Plant Pond (216-B-3). With B Plant operating and Purex Plant in standby, 216-B-3 Pond receives approximately $2,000 \mathrm{gpm}$ of water, and 216-A-25 Pond receives approximately $4,000 \mathrm{gpm}$, including that from the new 242-A Evaporator-Crystallizer which began operation 1977. 
When Purex is restarted, it will be operated in sequence with B Plant. Its cooling water flow rate when operating thereafter will rise to an annual average of about $4,300 \mathrm{gpm}$ and a monthly average of $5,000 \mathrm{gpm}$ for the seven months of the year during operations. The B Plant flow rate will drop from about $1,750 \mathrm{gpm}$ when operating (about four months of the year) to less than 1,000 gpm during standby. The 242-A EvaporatorCrystallizer will also be shut down during Purex Plant operating periods. Thus, no net increase in cooling water discharges will result from Purex Plant operation.

To optimize the Hanford Reservation groundwater management and obtain the desired hydrologic balance in the disposal areas, cooling water flows will be divided appropriately between 216-A-25 and 216-B-3 Ponds, as determined by the results of continuing hydrogeologic research. $A$ detailed discussion of the hydrology of the Hanford Reservation is given in ERDA-1538, Section II.3; the effects of cooling water releases to ground surface are discussed in Section III.I and III.2 of the same document.

There are no liquids, radioactive or otherwise, released from the Purex Plant operation to the Columbia River. Releases are to surface ponds or to underground cribs near the center of the Hanford Reservation from which there is little potential for public exposure via any of the possible pathways. These pathways and the estimated impacts on man and other biota of both radionuclide wastes and chemical wastes are also discussed in Section III.1 of ERDA-1538. The general conclusions are:

- A routine wildlife sampling program usually finds low levels of radionuclide contamination in waterfowl harvested from 200 Areas ponds and ditches. This is a minor contribution to the radiation exposure of the public; e.g., the maximum individual would receive less than 0.3 mrem if he ate 90 pounds of waterfowl flesh per year. 
- Minor amounts of radionuclides are sent to ground in the 200 Areas; with the possible exception of iodine and tritium, they are not entering the Columbia River via groundwater migration.

- Radiation doses from tritium and gross beta entry into the Columbia River during the peak years would be extremely small (less than $1 \times 10^{-6} \mathrm{mrem} / \mathrm{yr}$ to the maximum individual and less than 0.1 man$\mathrm{rem} / \mathrm{yr}$ to the local population).

- Because of chemicals discharged to ground from Purex and other 200 Area operations, nitrate is found in the groundwater beneath part of the Reservation. Some potential may exist for mammals and migratory waterfowl to accumulate nonradiological pollutants such as heavy metals, although there is no evidence of any effects.

- There is no evidence of significant migration (other than nitrate) or environmental impacts of industrial chemicals discharged to the surface of the ground via the Purex chemical sewer. (Nitrate in the groundwater is discussed in Section III.1.6 of ERDA-1538.)

\section{Gaseous Effluents}

The gaseous effluent released from the Purex Plant main exhaust stack contains oxides of nitrogen that are produced during uranium dissolution and waste deacidification. At peak dissolving rates, which occur approximately 10 percent of the time during processing, the stack effluent at 125,000 cfm contains approximately 700 to $1300 \mathrm{ppm}$ of $\mathrm{NO}_{\mathrm{x}}$, with the maximum being about 1,000 ppm.

Occupational exposures to oxides of nitrogen have been determined by sampling to be less than $0.3 \mathrm{ppm}$ for peak concentrations on an hourly average and less than $4 \mathrm{ppm}$ for 30 -second peak concentrations, even when the stack effluent concentration has reached 1,000 ppm. The threshold limit value (TLV) for an eight-hour working day is $5 \mathrm{ppm}$. Continuous air samplers checking $\mathrm{iJ}_{\mathrm{x}}$ concentrations at ground level near the Purex Plant will be in operation during future Purex fuel reprocessing. 
The concentration of $\mathrm{NO}_{x}$ in the air at the Reservation boundary is reduced by dispersion and dilution, by factors of from $10^{6}$ to $10^{8}$ below concentration values at the top of the stack. The $\mathrm{NO}_{x}$ released from the Purex Plant would have concentrations in the atmosphere at points on the boundary of less than $0.001 \mathrm{ppm}$ compared with the nonoccupational exposure limit of $0.05 \mathrm{ppm}$ annual average concentration for continuous breathing.

During prior years of operation, at peak dissolving rates, the typical red-brown color characteristic of $\mathrm{NO}_{2}$ has occasionally been visible in the Purex Plant gaseous discharge plume when viewed from nearby locations outside the boundary of the Hanford Reservation. Although opacity measurements had never been made up to the time of plant shutdown in 1972, it is probable that Washington State's present 20 percent opacity standard was exceeded at these peak times at the point of gaseous discharge into the atmosphere. This issue has been discussed with regulatory agencies and a separate opacity limit (possibly 40 percent) is being considered for Purex. Purex will be in compliance with all limits at startup. Ine cost for facilities to be in compliance could be up to $\$ 8$ million.

The combined nitrogen oxide release from the fuel dissolving and waste denitration steps totals approximately 290 pounds of $\mathrm{NO}_{2}$ per ton of uranium processed. In 1983-1984 therefore, this will represent approximately 150 tons of $\mathrm{NO}_{2}$ discharged from the Purex Plant, or about one-fifth of the amount released from the 200 Area powerhouses as shown in Table III. 9.

The amounts of coal burned in the 200 Area powerhouses during calendar year 1972 and the resulting emissions of pollutants are given in Section II.1.1.6 of ERDA-1538. Similar data have been estimated and are given in Table III.9, showing forecasted 1977-1978 emissions (Purex Plant not operating) compared with 1983 (Purex Plant operating). 
TABLE III.9

ANNUAL EMISSION OF POLLUTANTS FROM 200 AREA POWERHOUSES

\begin{tabular}{|c|c|c|c|c|}
\hline Year & $\begin{array}{c}\text { Coal } \\
\text { Consumption } \\
\text { (tons) }\end{array}$ & $\begin{array}{l}\text { Sulfur } \\
\text { oxides } \\
\text { (tons) } \\
\end{array}$ & $\begin{array}{c}\text { Nitrogen } \\
\text { Oxides } \\
\text { (tons) } \\
\end{array}$ & $\begin{array}{c}\text { Particulates } \\
\text { (tons) }\end{array}$ \\
\hline 1972 & 57,000 & 650 & 430 & 3,400 \\
\hline $1977-1978^{(a)}$ & 93,000 & 1,060 & 700 & 5,600 \\
\hline 1983 & $100,000^{(b)}$ & 1,140 & 760 & $5,900^{(c)}$ \\
\hline
\end{tabular}

(a) Annual averages for these two years.

(b) Consumption. expected to remain at about this level through 1983-1990.

(c) An emission control system for the boilers is planned for the 200 Area power houses to reduce the particulates to 0.1 grain per cubic foot per minute (opacity standard) in an effort to meet the Benton-Frank 1 inWalla Walla Counties Air Pollution Control Authority regulations. Estimated cost is $\$ 6.5$ million dollars.

The future increases of seven to eight percent above 1977-1978 emissions are the predicted result of Purex Plant operation for about seven months per year, in sequence with B Plant, which will operate about four months per year. By FY 1981, pollution abatement equipment consisting of bag-houses are proposed to be in operation to reduce particulate emissions from the stacks by factors of from 4 to 20 depending on the powerhouse operating modes and rates. Expected emissions would be below local, state and federal standards by at least a factor of two. Sulfur oxide concentrations that are currently below the level of the present standard would be further reduced but there would be no significant change in oxides of nitrogen concentrations. Incremental annual operating costs would be $\$ 40,000-45,000$ in FY 1979 dollars.

\section{III.1.2.2 Solid Waste}

Ordinary trash estimated to be 90 percent paper and 97 percent combustible is collected, compacted by a factor of three, and buried in a 
central sanitary landfi11. Purex Plant output is a small fraction of the compacted volume of $360,000 \mathrm{ft}^{3} /$ year forecast for the entire Hanford Reservation.

\section{III.1.3 Natural Forces}

Accidents and resulting adverse environmental impacts can conceivabiy be initiated by natural forces such as earthquakes and tornadoes.

The Purex Plant and related facilities were built under the Uniform Building Code (UBC) applicable at the time of construction (1954-1955), which included seismic provisions and criteria for straight winds. State-of-the-art improvements in design, construction practices and construction materials were incorporated. Lateral wind forces, related to the areas of the structures, and lateral earthquake forces, related to the masses of the structures, were specified according to the UBC seismic provisions that designated Hanford as Zone 2 on the seismic risk map, which implies moderate damage if a quake should occur. The existing structures are capable of satisfactorily withstanding any future natural forces equal to those from any historically recorded natural forces events in this location.

Recent analytical studies that are being continued suggest that significant structural damage to the 202-A Building would result from the most severe probable earthquake (Safe Shutdown Earthquake) estimated to produce a horizontal acceleration at the Purex Plant of $0.25 \mathrm{~g} .(1,2)$ Where and how the damages would occuir in the structure have not been precisely defined, but cracking of canyon walls and joints, with some potential radionuclide release as a result, could be expected. However, the structure has been calculated to be capable of safely withstanding a ground acceleration of $0.15 \mathrm{~g}$ which corresponds to VII to VIII on the Modified Mercalli (MM) intensity scale. Such quakes are judged highly improbable; the quake giving an acceleration of $0.25 \mathrm{~g}$ has an occurrence probability of unlimited time span; the $0.15 \mathrm{~g}$ acceleration quake has an expected probability of once in 4,000 years. 
Under the $0.25 \mathrm{~g}$ quake ground acceleration, the two existing main ventilation filters would suffer some concrete cracking of the interior wall faces, but the tunnels and plenum would safely resist the Safe Shutdown Earthquake (SSE) motions. ${ }^{(4)}$ The third main ventilation filter, to be put in service following the Purex Plant startup (see Section II.3.1.8), has been designed for a $0.50 \mathrm{~g}$ static loading without a confirming dynamic seismic analysis for the SSE.

The Purex Plant ventilation system includes three electrically powered exhaust fans and one backup steam turbine exhaust fan. These are located above ground near the base of the exhaust stack. Only the steam turbine fan is enclosed in a concrete block structure. The fans and their anchorage to the foundations have not been evaluated for SSE motions. It is likely, however, that the electrical power, including the emergency source and the steam supply to the fans would be disrupted by such a quake. Only one fan is needed to provide minimum exhaust capacity for the Purex Plant, and an emergency unit could be put into service in a matter of hours, complete with mobile power supply.

Several studies have been made of the maximum wind speed and the probability of a tornado striking a specific location on the Hanford Reservation. These analyses conclude that the probability of a tornado hitting a particular facility onsite is six chances in one million during any given year or about one chance in 4,000 during a 40-year plant life. The maximum tornado wind speed for the Hanford site is estimated to be 175 miles per hour (mph).

The $175 \mathrm{mph}$ tornado conditions which could result are summarized as follows:

$\begin{array}{ll}\text { Wind Loads - } & \begin{array}{l}\text { Tangential speed } \\ \text { Translational speed }\end{array} \\ \text { Transient Pressure } & -0.75 \text { psi pressure decrease in three } \\ & \text { seconds, held for one second and } \\ & \text { returned to prior level at the same } \\ & \text { rate. }\end{array}$

$150 \mathrm{mph}$

$25 \mathrm{mph}$ 
Tornado Missiles - 2-inch $\times 12$-inch $\times 12$-foot-long wood plank traveling $100 \mathrm{mph}$.

4-foot $\times 8$-foot $\times 3 / 4$-inch-thick plywood sheet traveling $150 \mathrm{mph}$.

$26=$ inch-wide $\times 20$-foot-long sheet of 20-gauge corrugated steel siding traveling $150 \mathrm{mph}$.

The Purex Plant's massive concrete construction is expected to withstand all credible tornadic winds. The heavily shielded interior cells and process operations therein would suffer little or no damage. The tornado could, however, severely damage the control rooms and other facilities in the Annex, causing essentially a complete process cut off and loss of remote control. This situation, while being very serious from the standpoint of plant damage, would not result in significant offsite environmental impact. Advance warning of the approach of a tornado (even as little as 10 to 15 minutes) would allow the planned-for emergency shutdown of the remote operations. This would permit the process to be put into the most stable configuration possible in the time available thereby reducing still further the probability of adverse environmental impacts of the tornado.

The main exhaust ventilation filters are below the surface of the ground and are thus adequately protected; the exhaust stack would not be damaged. The four exhaust fans mounted at the base of the stack could be damaged. However, as noted above, an emergency unit could be in service within a matter of. hours.

Steam and electric utility supply lines are not tornado-resistant and could be put out of commission. Emergency systems are in place, but could also be damaged depending on the specifics of the tornado. Temporary repairs, adequate to reestablish control, could be made within 48 hours.

Support facilities outside the 202-A Building, such as chemical tanks, equipment warehouses, etc., could be damaged or destroyed. The contaminated equipment burial tunnels would not be affected. 
Although a few curies of radioactive contamination would be released (from the canyon deck and auxiliary vent systems), radionuclide concentrations in the air at the Hanford Reservation boundary should be less than the maximum value allowed by DOEM 0524 Appendix for uncontrolled areas, and there should be no discernible adverse effects offsite from this release.

The very low probability of a severe earthquake or tornado at the site, coupled with the relatively minor consequences which would be expected, results in an acceptable environmental risk for the projected operating period. Results of the effects of natural forces will be incorporated in the Safety Analysis Report (SAR) to be issued before the restart of the Purex Plant.

A flood on the 200 Area plateau during the operating lifetime of the Purex Plant is not credible (see ERDA-1538).

\section{III.1.4 Accident Impacts}

This section presents a summary of significant accidents that have occurred at the Purex Plant and a discussion of postulated credible accidents that could conceivably occur as the result of operating the Purex Plant and related facilities.

The impacts of the postulated accidents range from relatively minor to severe. In arriving at the list of five postulated accidents, conceivable accidents of many different types were studied, with emphasis on the conditions or circumstances that would be most likely to cause an abnormal event. Results of analytical studies will be included in the SAR. Rigorous engineering evaluations of possible accidents will be included.

Safety and accident considerations were limited primarily to events that could result in loss of confinement of the radionuclides. Nonradiation accidents and hazards are basically the same as those in other 
industrial facilities although Hanford safety codes are generally more stringent than normal industry. Since these kinds of accidents will have little or no environmental impact either onsite or offsite, they are not discussed.

During accident selection and analysis, a consistent attempt was made to be both realistic and pessimistically conservative in the assumptions used in an effort to define the upper limit of severity. In some cases, as many as three sequential or coincidental errors and/or failures of engineered preventives are required for the accident. ton orcur: Althougin this multicontingency factor reduces the probability of such an accident to an extremely low value, the probability is not zero. Therefore, the accidents are considered credible, even if highly unlikely, and have been evaluated.

The analyses of postulated accidents are reviewed by the responsible contractor engineering and operations management. Whenever credible potential accidents are judged to rcprcsent unacceptable risks or siynificant impact to the environment, even though their occurrence is very low in probability, the engineering features of the facilities and the operating procedures are reviewed and modified, as appropriate, on the basis of reducing the probability of the accident to as low as technically and economically practicable.

The methods used in estimating potential consequences of the postulated accidents are the same as those used in ERDA-1538, Appendix III-C.

The postulated accidents discussed in this section are:

- dissolving of short-cooled reactor fuels in the dissolver;

- uranium metal fire in the dissolver;

- organic solvent fire;

- inuclear criticality;

- cask car collision and fuel element fire. 
In addition to those events described below in Section III.1.4.1 that have occurred during past Purex Plant operation, the following radionuclide and energy release possibilities were considered in selecting the above five accidents that are postulated and analyzed in this section.

- Hydrogen or Ammonia Explosion in the Dissolver Cell. These gases are produced during the decladding step, but are diluted below the lower explosive limits with continuous air flow in the process vent system. An explosion in the dissolver cell could cause significant equipment damage and interior cell contamination, but little, if any, escape of radionuclides to the atmosphere. The in-cell filters and/or main ventilation exhaust filters would provide adequate protection. Pressure from the explosion would be largely damped before reaching the main filters and would have no effect on the filters. This type of accident has occurred in the Purex Plant. Due to an error in chemical addition to clad fuel elements in a dissolver, hydrogen was formed and subsequently detonated (ignition source unknown). The explosion was calculated to have produced a maximum overpressure of $26 \mathrm{psi-second} \mathrm{in} \mathrm{the} \mathrm{dissolver} \mathrm{and} \mathrm{off-gas}$ system. The dissolver lid and charging chute were blown off the dissolver and the silver reactor regeneration nozzle plug was ejected. The vessels were not deformed or otherwise damaged by the pressure. Damage was limited to impact distortion of $1 \mathrm{id}$ and chute, presumably due to contact with the under side of the cell cover block. There was no release of radioactivity from the plant.

- Silver Reactor Explosion in the Dissolver Cell. (See Section III.1.4.1).

- "Red 0il" ExpTosion in a Process Solution Concentrator. If this event should occur despite the established controls to prevent it, serious equipment damage and interior cell and canyon contamination would be expected. However, as in the hydrogen explosion, essentially all the radionuclides would be retained within the main 
Purex building and ventilation filters. The force of the explosion would lift the cell cover blocks momentarily, and this pressure relief, plus the damping effect between process cell and the main exhaust filters, would prevent any adverse impact on the filters. There has never been a red oil explosion in the Purex Plant.

- Damage and Impaired Efficiency of the Main Ventilation Exhaust Filters. The handling of radioactive nuclides in large quantities in the Purex Plant always presents a potential for environmentally significant hazardous accidents having offsite consequences. In most instances, in both actual and postulated accidents, the degree of severity of the environmental consequences is negligible or sharply limited by the effectiveness of the filters in the main ventilation exhaust system. Thus, any accident that damages or impairs the effectiveness of these filters could have adverse environmental impacts.

Such an accidenl cuuld be must 11kely one of three types:

(1) rupture or partial collapse of the filter, (2) fire, or (3) explosion.

Rupture or Collapse of the Filters. This could conceivably result from a seismic shock. However, the filter structures were analyzed with respect to their ability to withstand the SSE of Richter magnitude 6.8, producing horizontal acceleration of $0.25 \mathrm{~g}$ and vertical acceleration of $0.17 \mathrm{~g}$ (see Section III.1.3). On the basis of this st.lidy, it was concluded that the ventilation tunnels to the filters and from the filters to the stack plenum would survive the SSE motion without damage, but that some concrete cracking would probably occur on the inside faces of the filters' outer walls. Such cracking would not cause significant radionuclide release to the environment. The filters were built according to the UBC, incorporating provisions for Hanford construction in Zone 2 of the seismic probability map, and the likelihood of an earthquake large enough to destroy the filter is considered extremely remote. 
The prefilters are beds of packed glass fibers 84 inches thick supported by stainless steel frames anchored in the concrete. These are backed up by afterfilters of greater fiber density and different design (see Section II.3.1.5). Therefore, although the filter beds can and do tend to be plugged with collected solids that have in the past caused marked decreases in air flow and increases in pressure drop (accompanied by improved filtration efficiency), such pressure would not cause a blowout of the filter medium (a hole pulled through the bed) or cause the support frames to collapse. In any case, the filters are instrumented so that plugging and increased..pressure drop--which would not be instantaneous phenomena--would be monitored as a function of time. This was the case when partial plugging of the original Purex filter was experienced in 1962. Since then, changes made in process equipment and flow patterns have largely isolated the ammonia-bearing effluents from the main filters, thereby greatly reducing the solids loading on the filters. This has effectively reduced the probability of filter plugging.

Fire. This could occur in the process cells (e.g., the organic solvent recovery cell) or it could conceivably occur in the filter itself. Fire protection is provided in the process cells and ventilation exhaust tunnel, particularly for those cell locations in which organic solvent is handled in quantity. It is extremely improbable that a fire could start and persist long enough to heat $125,000 \mathrm{cfm}$ of air to a temperature that would cause serious deterioration of the filter, especially when the water sprays protecting the filter are considered (Section II.3.1.8).

The filter does collect combustibles such as lint and condensed organic solvent vapors. Therefore, it is conceivable that if these materials were somehow ignited (by embers from an in-cell fire, for example), their combustion could melt the glass fibers and partially destroy the filter medium. This could result in the discharge of part of the accumulated radionuclides from the stack into the atmosphere, but only if the afterfilter were also damaged by the heat and fire. 
The current estimated total radionuclide inventory on the two filters is as follows:

Nuclide

Cesium-134

Cesium-137

Cerium-144

Promenthium-147

Strontium-90 + Yttrium-90

Plutonium-238

Plutonium-239

Plutonium-240

Plutonium-241
Amount

(Curies)

200

2,000

600

1,800

3,400

10

30

20

1,900

Each prefilter is composed of three bays separated by concrete partitions; thus a fire would probably affect only one bay. Also, there are two main filters in parallel and it is improbable that both would burn simultaneously. The fire would not spread laterally through the medium because of the air draft, but would penetrate the glass fiber bed ton a depth determined, in part, by the combustible loading. It is possible but unlikely that penetration would go completely through the bed. Moreover, there would be little or no inventory of combustibles on the afterfilter.

Although this type of accident has never happened, it must be considered a remote probability. Dispersal of radioactive material offsite could occur, with the degree of seriousness dependent on the specific accident conditions. This is being evaluated in the Safety Analysis Report (SAR) now in preparation.

The glass fiber packing would melt at the higher temperatures, and would tend to trap and hold most of the radionuclide burden in the agglomerated melt. Some dust and semivolatile elements, such as cesium, could be expected to escape. Ventilation supply air flow would be cut 
off, rapidly limiting the duration of the fire, and would probably have to be cut off entirely until emergency backup filtration for the exhaust could be provided. The contaminated leakage from the plant would be more a work area contamination cleanup problem than one of offsite consequences. Risk to the public is considered very small because of the extremely low probability of such an accident.

Explosions. An explosion in a process cell, such as with hydrogen or red oil or silver azide (as experienced in 1958), would not significantiy affect the main exhaust filter. Probably the most violent explosion that could be expected would be that of red oil in a concentrator. It has been calculated that this would rupture the concentrator vessel and lift the cell cover block momentarily, largely relieving the cell pressure into the canyon area. The pressure wave from the process cell into the ventilation tunnel and up to the filter would be so damped by expansion, time and distance, that no damage would result to the filter and no significant radionuclide release to the stack would result.

Prevention of accidents and protection against the occurrence of postulated accidents at the Purex Plant, are provided through design and construction features and proper operation of the facilities. A formal quality assurance program is in place covering new projects, materials, construction, procedures and operations of the total system. Despite this, however, accidents can and do occur.

Plant operations result in a wide variety of abnormal events or accidents of a minor nature, ranging from the failure of an instrument, a pump or an electrical circuit, or the spill of a radioactive sample, to more serious and costly events such as the failure of a major piece of process equipment, the break of a buried waste transfer line, or a localized fire and contamination spread. These types of events are anticipated and have occurred as shown in the following section. Plant design and operations procedures are predicated on the recognized need to cope with any event, and to protect the public, the employees 
and the plant facilities. Performance has been good. Most such accidents have been, in general, limited in scope and effect, and have usually been confined to a small area or contained within the plant operating zones. Events involving radioactive contamination have been dealt with promptly, rapidly and effectively, to limit potential spread and maintain control while conducting cleanup and restoring operations to normal.

In terms of costs, process interruptions, equipment losses, localized radionuclide contamination and cleanup operations, some of the accidents mentioned above could and wnuld be serious; some would be nuisance items only. However, from the standpoint of releases to anil impacts on the environment, they would not be as serious as the postulated accidents presented in the sections that follow and therefore they have not been analyzed or discussed further.

The Purex Plant is a nonreactor nuclear facility processing large quantities of fissile material. Operations are based on nuclear criticality safcty specificatiuns (implemented by formal written procedures), developed in accordance with contractor operating policy, that meet the requirements of DOEM 0530 RL Appendix, as verified by independent nuclear satety and technical reviews. The speclfications establish limits so that no single credible equipment or process failure or human error can cause a criticality in a shielded facility. In an unshielded facility, the limits are set so that no two credible independent, co-existing equipment or process fallures or human errors can cause a nuclear criticalit.y. Such failures are provented mechanically by the use of critically favorable geometry in equipment design. or administratively by the formal specifications and procedures that require safe fissile solutions and/or batch sizes. Internal company audits and appraisals are performed by competent technical and quality assurance personnel (other than those responsible for facility operation) to assure compliance of operation to the specifications and procedures. Such audits and appraisals have resulted in improved specifications, procedures and operations. The audits have also resulted in improved training and documentation thereof. 
In addition, independent reviews have occasionally been made in the past by outside nuclear criticality experts evaluating the overall criticality safety program. These reviews have both confirmed the basic adequacy of this program, and have suggested detailed improvements in it that have been implemented.

A fire protection review of the Purex Plant was made in late 1970 by Factory Mutual Research Corporation. The resulting principal recommendations relating to inspections, installations of detection and automatic fire extinguishment systems, equipment modifications and administrative controls, have been implemented, or are planned for completion before resumption of Purex Plant production operations. The Factory Mutual representatives revisited the Purex Plant in August 1975 but did not make any new recommendations.

In accordance with all applicable policies, detailed reviews and investigations are made following abnormal occurrences and accidents. Causes are determined and a search is made for similar conditions elsewhere; generic solutions to the problems are sought for prevention of repeat or related types of accidents. Appropriate process improvements, equipment design changes, administrative controls and engineered safety features, are put in place to minimize the probability of the recurrence of such accidents.

\section{III.1.4.1 Historical Accidents}

Significant accidents that have occurred in Purex Plant operation and that have involved potential or actual impacts onsite and offsite, are given in Table III.10. They are listed in chronological order following the start of Purex Plant operations, along with a qualitative estimate of the consequences.

In addition to the more significant events summarized in Table III.10, there have been other incidents involving loss of radiation control that had no effect on the environment or on the general public. They have 
TABLE III. 10

\section{PUREX PLANT HISTORICAL ACCIDENTS WITH POTENTIAL ENVIRONMENTAL IMPACTS}

2-22-56 A blowback of plutonium contamination occurred from the Purex $L$ Cell into the operating gallery. The contamination was reduced to as low as pracțicable level and the gallery was painted.

2-13-58 An explosive chemical reaction occurred in a silver reactor in a'dissolver cell. The chemical compounds involved are believed to be azides formed from reaction of ammonia with silver salts. The source of the ammonia was either an ammonium hydroxide flush solution or the off-gas from the aluminum coating removal operation in the dissolver. ilo abnormal temperature or pressure changes were evident immediately before the explosion. Causes of the energy release at the time are unknown. Cell damage was repaired and new equipment was installed.

2-25-60 Sparks from a welding torch ignited twn small fires in Purex it Cell containing ion exchange equipment; the fires spread to a hood air inlet filter. Openings in the hood as a result of the fire allowed contamination (plutonium) to be spread to the surrounding work areas up to $60,000 \mathrm{dis} / \mathrm{min}$ per $100 \mathrm{~cm}^{2}$. A11 personnel involved were wearing prescribed protective clothing and equipment (masks). The personnel were cleaned, the area was decontaminated, and equipment was repaired and replaced.
Estimated Environmental Consequences

Decontamination of the gallery resulted in contamination of water and mud in chemical sewer up to $10^{-4}$ to $10^{-3} 4 \mathrm{Ci} / \mathrm{ml}$. There was no offsit.e impart..

The equipment was damaged but there was no discernible release of radionuclides to the environment.

in evidence was found of radionuslido releases from the plant. Workers sustained some skin contamination. 


\section{TABLE III.10 (continued)}

Date

$4-13-61$

$4-20-61$

$7-1-61$

$9-3-63$
Brief Description of Accident

Approximately 30,000 gallons of nitric acid were lost to the chemical sewer as a result of valves being left open.

Uranyl nitrate $(1,335$ pounds of depleted uranium) was lost to ground when a tank trailer overfilled. The mistake was due to human error and misunderstanding. The contaminated soil was removed and buried and equipment was cleaned and returned. to service.

Approximately 20,000 square feet of ground near the Purex building was found to be contaminated by particulates up to $100,000 \mathrm{c} / \mathrm{m}$ (fission products). When repaired steam trap facilities were being tested, a heavy plume of steam was emitted from the pit containing the steam traps causing the contamination spread. Water was spread over the area to fix the contamination and then the top few inches of soll were graded off to remove radionuclides and buried.

Radioiodine was released into the atmosphere when "green" (shortcooled) reactor fuel was unknowingly charged into the dissolver and dissolving was started. The process was stopped as quickly as possible, and. steps were taken to retain as much of the radioiodine in the plant as possible.
Estimated Environmental Consequences

There were no injuries and no effects outside the Hanford Reservation.

No contamination was spread beyond the immediate $100 \mathrm{ft}^{2}$ area of the spill; there were no offsite effects.

No evidence of radionuclide release offsite from this event was found.

A total of $62 \mathrm{Ci}$ of ${ }^{131}$ I was released over the three-day period. Temporary increases were noted in the amount of ${ }^{131}$ I in the environs. Special milk samples contained on the order of $100 \mathrm{pCi} 131$ I per liter, an order of magnitude greater than normal. The best estimate of the maximum $131_{\text {I }}$ concentration in milk that occurred from this emission was $\sim 500 \mathrm{pCi}$ per liter. The maximum total thyroid radiation exposure which could have been received by an individual drinking milk from this source would have been about 0.4 rem, compared with the DOE Appendix 0524

standard of 1.5 rem maximum annual thyroid dose for an individual in an uncontrolled area. 


\section{TABLE III.10 (continued)}

\section{Brief Description of Accident}

A leak in the cooling coil of the waste sampling tank (F-15) allowed on the order of 100,000 $\mathrm{Ci}$ of mixed fission products to be released to $B$. Swamp and Gable Mountain Swamp.
Estimated Environmental Consequences

The general 1 and area surrounding the swamps was not contaminated during or after the accident. Traces of radioactive material reached the groundwater below the swamps but concentrations estimated to be about drinking water limits presented no radioingiral prohlem. The hull of the radioactive material that has not decayed at the present date remains associated with the bottom sediments of the swamps.

There was no contamination outside the Purex Plant exclusion area.

ito contamination was found outside the ?nO Fast. Aroa.
iNo spread of contamination occurred beyond the affected surfaces and solis beside the roadway. The area was decontaminated. 
impacted, however, on the employees and on the Purex facilities operations. A summary of these incidents since 1966 is given in Table III.11. The impacts of these occurrences on the employees and on the operation of the Purex facilities have been minor in all cases. None of the injuries was disabling, and there was no loss of employee time from work other than that which may have been involved on the day of the incident. None resulted in loss of plant production.

\section{TABLE III. 11}

PUREX PLANT RADIATION CONTROL EXPERIENCE, $1966-1972^{(a)}$

\begin{tabular}{|c|c|c|c|}
\hline Year & $\begin{array}{l}\text { Number of } \\
\text { Contamination } \\
\text { Occurrences } \\
\end{array}$ & $\begin{array}{l}\text { Number of Contamination } \\
\text { Injuries (Skin Broken) }\end{array}$ & $\begin{array}{l}\text { Number of Internal } \\
\text { Deposition, Casses } \\
>5 \% \text { MPBB (b) }\end{array}$ \\
\hline 1966 & 25 & 4 & -- \\
\hline $196 \overline{7}$ & 21 & - & -- \\
\hline 1968 & 62 & 1 & $f^{(c)}$ \\
\hline 1969 & 41 & -- & 1 \\
\hline 1970 & 36 & - & -- \\
\hline 1971 & 34 & 1 & $4^{(d)}$ \\
\hline 1972 & 20 & 4 & $=-$ \\
\hline
\end{tabular}

(a) Purex Plant has not operated since 1972.

(b) Greater than 5\% maximum permissible body burden (MPBB).

(c) One employee received a plutonium deposition of $15 \%$ of the MPBB . from a contamination injury; this is the maximum case in Purex Plant experience.

(d) Two employees without respiratory protection received fission product depositions, primarily $106 \mathrm{Ru}$, of 5 and $10 \%$ of the MPBB while observing movement of equipment in the railroad tunnel. Their body burdens are now less than 1\%. The other two employees received 8 and 10\%, respectively, of the systemic MPBB of plutonium. 


\section{III.1.4.2 Postulated Dissolving of Short-Cooled Reactor Fuels}

In this postulated accident, it is assumed that a canister of Mark I-A N Reactor fuels (worst case) cooled only 25 days after discharge would be shipped to the Purex Plant in a caskload of properly cooled elements ${ }^{\star}$ and partially dissolved. (See Section II.3.1.3 for a description of the fuels.)

The shipping cask for the Mark I-A fuels is dividen into four compartments, each containing one twin-barrelled canister holdiny 42 fuel elements, totaling approximately 1,500 pounds of uranium. For the purpose of this accident analysis, it is assumed that all of the elements in these four canisters, plus three or four more to make a complete charge, would be put into a dissolver containing no metal heel. A full charge can be up to the maximum of 12,000 pounds under these conditions. The total charge is dissolved in one "cut" when Mark I-A fuel is processed, taking 12 to 15 hours for the complete dissolution step.

When nitric actd is added, the initial dissolving reaction is extremely vigorous, due to the presence of a large amount of fine oxides resulting from the decladding step, and the reaction is difficult to stop. The fuel dissolution rate is 1,500 to 2,500 pounds per hour for the first two or three hours; the rate drops markedly thereafter as the amount of undissolved metal decreases toward zero.

For this accident, it is assumed that the reaction would proceed for three hours before the situation was diagnosed and the dissniving stonpperd. In this time, approximately 60 percent of a 12,000-pound charge, including 1,000 pounds of the inadequately cooled metal, would be dissolved. The source term for this accident is given in Table III.12.

*A17 fuels are to be aged a minimum of 175 days before being reprocessed in the Purex Plant. 


\section{TABLE III. 12}

RADIONUCLIDES RELEASED FROM PUREX PLANT DURING POSTULATED DISSOLVING OF SHORT-COOLED FUEL (a)

\begin{tabular}{|c|c|c|c|c|c|}
\hline Nuclide(b) & $\frac{\text { Quanti }}{\text { Unaged Fuel(c) }}$ & $\begin{array}{l}\text { Dissolved (Ci } \\
\text { Aged Fuel(d) }\end{array}$ & Total & $\begin{array}{l}\text { Percent Released } \\
\text { from Plant } \\
\end{array}$ & $\begin{array}{l}\text { Quantity Released } \\
\text { To Atmosphere (Ci) }\end{array}$ \\
\hline $131 \underline{m}_{\mathrm{xe}}$ & $1 \times 10^{3}$ & - & $1 \times 10^{3}$ & 100 & $1 \times 10^{3}$ \\
\hline $133 \mathrm{xe}$ & $2 \times 10^{4}$ & - & $2 \times 10^{4}$ & 100 & $2 \times 10^{4}$ \\
\hline${ }^{129} \mathrm{I}$ & $1 \times 10^{-3}$ & $6 \times 10^{-3}$ & $7 \times 10^{-3}$ & 0.1 & $7 \times 10^{-6}$ \\
\hline${ }^{131} 1_{I}$ & $3 \times 10^{4}$ & - & $3 \times 10^{4}$ & 0.1 & 30 \\
\hline${ }^{132} I$ & $2 \times 10^{3}$ & - & $2 \times 10^{3}$ & 0.1 & 2 \\
\hline${ }^{85} \mathrm{Kr}$ & $5 \times 10^{2}$ & $3 \times 10^{3}$ & $4 \times 10^{3}$ & 100 & $4 \times 10^{3}$ \\
\hline $3_{H}$ & 15 & 90 & 105 & 5 & 5 \\
\hline${ }^{14} \mathrm{C}$ & $4 \times 10^{-2}$ & $2 \times 10^{-1}$ & $2 \times 10^{-1}$ & 1 & $2 \times 10^{-1}$ \\
\hline \multicolumn{6}{|c|}{$\begin{array}{l}\text { (a) Irradiated at } 11 \mathrm{MW} / \text { tonne to } 3,000 \mathrm{MWd} / \text { tonne; aged } 25 \text { days after discharge. } \\
\text { (b) All other radionuclides are nonvolatile under dissolving conditions and remain in } \\
\text { dissolver. } \\
\text { (c) Estimated } 1,000 \mathrm{lb} \text { of } 1,500-1 \mathrm{~b} \text { charge dissolved in } 3 \text { hours. } \\
\text { (d) Estimated } 6,000 \mathrm{lb} \text { of } 10,500-1 \mathrm{~b} \text { charge dissolved in } 3 \text { hours. }\end{array}$} \\
\hline
\end{tabular}


Accident Preventives or Mitigating Conditions

Although this accident could result in offsite contamination, the probability of its occurrence, and therefore the risk, are very low for the following reasons:

- The $N$ Reactor operating contractor has established rigorous operating procedures and administrative controls to prevent the shipment of inadequately aged fuel elements to the Purex Plant.

- Cask cars are equipped with thermometers to indicate the temperature of the water in which the fuels are shipped; this temperaturc would be abnormally high if unaged fuels were in the cask, and should be observed on receipt at the Purex Plant. Current administrative controls specify that the fuels shall be returned to $N$ Reactor if a high temperature situation arises, which can be inferred or determined to be the result of inadequate aging of the fuels in the reactor basin.

- Fuels in cask cars are brought into the Purex Plant tunnel and are removed canister by canister by means of the remotely operated crane. As each canister is lifted into the 202-A Building canyon to be put into the dissolver, it is viewed by a high-radiation monitoring device (HM chamber [ in the railroad tunnel. This monitor is calibrated to trigger an alarm in the crane cab and in the dispatcher's office when the radiation from the fuel canister exceeds the predetermined level that indicates shorter-than-normal fuel aging. Thus, it would be necessary for the alarm level of the monitoring instrument to be improperly set; or for it to be inoperative with this condition unnoticed.

- The dissoiver off-gas system includes a silver nitrate reactor designed for the removal of radioactive halogens (primarily iodine isotopes) from this dissolver effluent. This would reduce the iodine release by an average factor of 500 . 
If an accident were to happen despite the preceding preventives, radioiodine monitors on the dissolver off-gas stream and in the 293-A Backup Facility would signal the increased emission and sound an alarm in the head-end control room, probably within 15 to 30 minutes. Prompt action in response to the alarm, such as emergency drowning of the reaction with water and removal of the acid from the dissoiver, would have the peak of the dissolving suppressed within 30 minutes. However, it is assumed that two to three hours would elapse before the dissolution could be completely stopped by diluting, cooling, jetting out the acid, or a combination of these actions.

\section{Source Term for Postulated Dissolving of 'Inadequately Aged Fuel}

For purposes of this analysis, a conservative (i.e., pessimistic) assumption is made, as follows: 1,500 pounds of 25-day aged fuel is mixed with 10,500 pounds of 175-day aged fuel and charged to the dissolver. In the two to three hours required to detect and stop dissolution, 1,000 pounds of unaged fuel and 6,000 pounds of aged fuel are dissolved. The potential emission of the major volatile nuclides was estimated.

For iodine, it is assumed that 50 percent of the total would remain in the dissolver solution and would be routed to underground storage via the liquid waste stream. The remaining iodine would be routed to the off-gas system which includes the silver reactor and the 293-A Backup (acid recovery) Facility. The silver reactor provides a decontamination factor of 500 . The net emission of iodine would be 0.1 percent. It is also estimated that 100 percent of the noble gases and five percent of the tritium ${ }^{(5)}$ in the dissolved metal would be released. Al though the chemistry of carbon in this acid dissolving system is not well defined, it is estimated that one percent of the carbon-14 would be released to the atmosphere. Estimated total potential release is shown on Table III.12.

Because of the accidental presence of the short-aged fuels in the Purex Plant, some subsequent delayed emissions of radionuclides would be expected during the post-accident recovery period. However, based on 
the maximum effort that would subsequently be made to stabilize the situation and retain the radionuclides in the plant to allow maximum radioactive decay, it is judged that releases could be held to approximately the limits of DOEM 0524 Appendix, Annex A, Table I (for controlled areas) throughout the following period required for eventual reprocessing and complete removal of this fuel from the plant.

Calculated Radiation Doses From Postulated Dissolving of Short-Cooled Fuel

The calculated radiation doses and impacts of this accident are given in Table III.13 for the maximum offsite individual and for the population within a $50-$ mile radius of the Purex Plant.

\section{TABLE III. 13}

\section{CALCULATED RADIATION DOSES FROM POSTULATED} DISSOLVING OF SHORT-COOLED FUEL

\begin{tabular}{|c|c|c|c|}
\hline \multicolumn{2}{|c|}{ First-Year Doses } & \multicolumn{2}{|c|}{$\begin{array}{c}50-Y r \\
\text { Dose Commitments }\end{array}$} \\
\hline $\begin{array}{l}\text { Maximum } \\
\text { Indf } 1 \text { vidual } 1 \\
\text { (rem) }\end{array}$ & $\begin{array}{c}\text { Population } \\
\text { Dose } \\
\text { (man-rem) }\end{array}$ & $\begin{array}{l}\text { Maximum } \\
\text { Individual } \\
\text { (rem) }\end{array}$ & $\begin{array}{c}\text { Population } \\
\text { Dose } \\
\text { (man-rem) }\end{array}$ \\
\hline
\end{tabular}

Externa1

Whole Body

$$
5.5 \times 10^{-4}
$$

$2 \times 10^{-1}$

$5.5 \times 10^{-4}$

$2 \times 10^{-1}$

Inhalation

Whole Body (Sol.) $8.6 \times 10^{-5} \quad 1.4 \times 10^{-2}$

Lungs (Sol.)

$9.1 \times 10^{-5}$

$1.5 \times 10^{-2}$

$8.6 \times 10^{-5}$

$1.4 \times 10^{-2}$

Bone (Ins01.)

$9.7 \times 10^{=4}$

$1.6 \times 10^{-1}$

$9.1 \times 10^{-5}$

$1.5 \times 10^{-2}$

Thyroid (Sol.)

$4.7 \times 10^{-2}$

$7.7 \times 10^{0}$

$9.7 \times 10^{-4}$

$1.6 \times 10^{-1}$

$4.7 \times 10^{-2}$

$7.7 \times 10^{0}$ 


\section{III.1.4.3 Postulated Uranium Metal Fire in the Dissolver}

In this postulated accident, it is assumed that $N$ Reactor Mark IV fuel* would be charged into a Purex dissolver, and that the Zircaloy cladding would be chemically removed in the routine manner; however, before dissolving of the bare uranium started, the metal would spontaneously ignite. The fire would burn through the stainless steel shell of the dissolver before being correctly diagnosed and extinguished, and would release gross quantities of radionuclides into the cell. It is assumed that three tons of uranium would be oxidized in 10 hours.

At equilibrium operation in the reprocessing of $N$ Reactor Mark IV fuel, a new charge of about 11 tons of fuel is put into the dissolver on top of a residual undissolved heel of one or two tons of fuel from preceding charges. The metal is normally kept immersed completely in either water or one of the process solutions such as ammonium fluoride-ammonium nitrate mixture or nitric acid.

For the purpose of this accident analysis, it is assumed that following decladding but before dissolving, the bare metal would not be . covered with water as required. A similar situation could arise between the first and second dissolving cuts.

Fission product decay heat, combined with close metal packing and poor heat dissipation conditions in the dissolver, would raise the temperature of the bare metal to $200^{\circ}$ to $300^{\circ} \mathrm{F}\left(100^{\circ}\right.$ to $\left.150^{\circ} \mathrm{C}\right)$. In the presence of oxygen and moist air or steam, the uranium would react to form oxides and hydrides (known to be important intermediates), thus continuing to accelerate the rate of temperature increase. At a temperature of $575^{\circ}$ to $600^{\circ} \mathrm{F}\left(300^{\circ}\right.$ to $\left.315^{\circ} \mathrm{C}\right)$, ignition would occur. This heating/ignition cycle would take varying lengths of time depending on

\footnotetext{
*See Section II.3.1.3. Note that this fuel is different from that in the preceding accident. Mark. IV is assumed here because the amount charged into the dissolver is larger than in the case of the Mark I-A, and thus a greater probability would exist for exposure of the metal above the liquid level.
} 
such factors as uranium history, rate of temperature rise, air flow rate and heat loss rate. In this case, it is assumed to take from 18 to 36 hours.

The heat produced by burning uranium is about 2,270 Btu per pound $(1,260$ calories per gram). The temperature, which could.go as high as $2,400^{\circ}$ to $2,500^{\circ} \mathrm{F}\left(1,300^{\circ}\right.$ to $\left.1,400^{\circ} \mathrm{C}\right)$ in the course of the fire, would result in the formation of various uranium eutectics with the components of the stainless steel -- all having lower melting points than that of uranium at $2,070^{\circ} \mathrm{F}$-- thus melting or "burning" a hole through the dissolver wall.

For this accident analysis, it is assumed that the uranium would burn at a uniform rate of 0.3 ton per hour and that it would continue for a minimum of three hours and a maximum of 10 hours before detection and extinguishment. Releases are given in curies per hour, but 10 hours was assumed to define the upper limit of duration and severity of consequences. In the rourse of the fire, a11. the noble gases, iodines, ${ }^{14} \mathrm{C}$ and tritium in the burned fuel would be released from the dissolver, along with an estimated one to 10 percent portion of many other radionuclides and/or their oxides that are volatile at the high temperatures ranging up to $2,400^{\circ}$ to $2,500^{\circ} \mathrm{F}$. With the dissolver shell breached by molten uranium, it is assumed that 20 percent of the radionuclides would escape into the cell, and would be swept into the ventilation tunnel and then into the main ventilation filter. The remaining 80 percent would be carried into the dissolver off-gas system in the cell; those getting through the in-cell filter and the secondary filter would be carried into the backup acid recovery system in the 293-A Building, from which the off-gas enters the plenum and the main stack for discharge to the atmosphere.

When the fire is discovered, it would be flooded with water at the rate of 25 to $30 \mathrm{gpm}$ from the "drown" tank, and would be extinguished within 30 minutes. The abrupt steam pressurization from the hot metal and water contact would displace the dissolver cover (a full-diameter 
rimmed plate held in place by gravity), and would release a surge of radionuclides into the cell and through the dissolver off-gas system. The steam eruption would cause no additional equipment damage because the pressure would be readily dissipated through the lidless dissolver into the cell. Steam would continue to be evolved for some time, but both the in-cell filter and the main ventilation exhaust filter would function normally to keep incremental radionuclide releases to the environment to negligible levels.

No significant surge of steam would reach the main exhaust filter because of the cooling and 20-to-30-fold dilution by the exhaust air stream in the main ventilation tunnel.

The failed dissolver would have to be emptied before removal for repair or discard. This would be done by standard chemical flowsheet methods with nitric acid, but the process would probably take considerable time and special operating procedures because of the hole in the dissolver shell. Since this operation would be done slowly over a period of many days or even weeks under special precautions for containment, the incremental radionuclide releases would be negligible when compared to those from the fire itself.

Accident Preventives or Mitigating Conditions

Although this accident would cause considerable equipment damage and internal radioactive contamination of the process cell, most of the radionuclides would be retained within the process cell and ventilation system. The probability of occurrence, and therefore the risk, are very low for the following reasons:

- Operating procedures specify immersion requirements and allowable lengths of time that bare fuels may be exposed above liquid levels.

- The dissolver is equipped with instrumentation for monitoring both the temperature of the solution and the temperature of the wall of the annulus containing the reactor fuels. These instruments indicate and alarm in the head-end control room. 
- The 291-A Stack and the 293-A Backup (acid recovery) Facility are equipped with sampling and radiation detection devices that would signal abnormal radionuclide concentrations in circumstances such as the postulated fire. Also, the dissolver off-gas radioiodine monitor would alarm in the head-end control room and indicate abnormal conditions at a time when dissolving was not in progress. These would aid in early detection and reduction in scope and seriousness of the accident.

Source Term for The Postulated Uranium Fire in the Dissolver

The radionuclide releases resulting from the fire in the dissolver are given in Table III.14.

Calculated Radiation Doses from Postulated Uranium Fire in Purex Dissolver

The calculated radiation doses and impacts of this accident are given in Table III.15 for the maximum offsite individual and for the general population within a 50 -mile radius of the Purex Plant.

\section{III.1.4.4 Postulated Organic Solvent Fire in G Cell}

In this postulated accident, it is assumed that solvent would leak from the Solvent Treatment System number 1 in $G$ Cell. and ignite in the cell.

It is assumed that the solvent, 30 volume percent tributyl phosphate (TBP) in 70 volume percent normal paraffin hydrocarbon (NPH), would be ejected from a faulty connection in the line at the top of the G-1 Tank, and would accumulate to a volume of about 2,000 gallons in the bottom of $G$ Cell. This volume is about the maximum that might go unmissed from a process material balance standpoint.

Under normal conditions, no mechanism of ignition is likely in $G$ Cel1, but there are potential sources of ignition, such as an overheated pump bearing or electrical sparks from faulty connections or equipment. (Motors are fan-cooled and totally enclosed, and are thus unlikely sources of ignition.) 


\section{TABLE III. 14}

\section{RADIONUCLIDES RELEASED TO ENVIRONS FROM POSTULATED URANIUM FIRE IN PUREX DISSOLVER(a)}

\begin{tabular}{|c|c|c|c|c|}
\hline Nuclide & $\begin{array}{l}\text { Concentration } \\
(\mathrm{C} i / \text { ton }) \\
\end{array}$ & $\begin{array}{l}\text { Quantity Released }(b, c) \\
\text { from Dissolver }(\mathrm{Ci} / \mathrm{hr})\end{array}$ & $\begin{array}{l}\text { Fraction Released } \\
\text { from Plant(d) } \\
\end{array}$ & $\begin{array}{l}\text { Quantity Released to } \\
\text { Environs (Ci./hr) }\end{array}$ \\
\hline${ }^{95} \mathrm{Nb}$ & $2.3 \times 10^{5}$ & $6.9 \times 10^{2}$ & 0.005 & 3.5 \\
\hline${ }^{144} \mathrm{Pr}$ & $1.6 \times 10^{5}$ & $4.8 \times 10^{2}$ & 0.005 & 2.4 \\
\hline${ }^{144} \mathrm{Ce}$ & $1.6 \times 10^{5}$ & $4.8 \times 10^{2}$ & 0.005 & 2.4 \\
\hline${ }^{95} \mathrm{Zr}$ & $1.3 \times 10^{5}$ & $3.8 \times 10^{2}$ & 0.005 & 1.9 \\
\hline $91_{Y}$ & $9.3 \times 10^{4}$ & $2.8 \times 10^{2}$ & 0.005 & 1.4 \\
\hline${ }^{89} \mathrm{Sr}$ & $6.1 \times 10^{4}$ & $1.8 \times 10^{2}$ & 0.005 & $9.0 \times 10^{-1}$ \\
\hline $103 m_{R h}$ & $3.3 \times 10^{4}$ & $9.9 \times 10^{1}$ & 0.005 & $5.0 \times 10^{-1}$ \\
\hline $103_{\mathrm{Ru}}$ & $3.3 \times 10^{4}$ & $9.9 \times 10^{2}$ & 0.005 & 5.0 \\
\hline${ }^{147} 7_{P_{m}}$ & $2.8 \times 10^{4}$ & $8.4 \times 10^{1}$ & 0.005 & $4.2 \times 10^{-1}$ \\
\hline${ }^{106}{ }_{R h}$ & $2.8 \times 10^{4}$ & $8.4 \times 10^{?}$ & 0.005 & $4.2 \times 10^{-1}$ \\
\hline${ }^{106} \mathrm{Ru}$ & $2.8 \times 10^{4}$ & $8.4 \times 10^{2}$ & 0.005 & 4.2 \\
\hline${ }^{141} \mathrm{Ce}$ & $2.7 \times 10^{4}$ & $8.2 \times 10^{1}$ & 0.005 & $4.1 \times 10^{-1}$ \\
\hline${ }^{137} \mathrm{Cs}$ & $8.7 \times 10^{3}$ & $2.6 \times 10^{2}$ & 0.005 & 1.3 \\
\hline $137 m_{8 a}$ & $8.3 \times 10^{3}$ & $2.5 \times 10^{1}$ & 0.005 & $1.3 \times 10^{-1}$ \\
\hline $90_{y}$ & $7.8 \times 10^{3}$ & $2.3 \times 10^{1}$ & 0.005 & $1.2 \times 10^{-1}$ \\
\hline${ }^{90} \mathrm{sr}$ & $7.8 \times 10^{3}$ & $2.3 \times 10^{1}$ & 0.005 & $1.2 \times 10^{-1}$ \\
\hline $95 m_{N b}$ & $1.6 \times 10^{3}$ & 4.8 & 0.005 & $2.4 \times 10^{-2}$ \\
\hline${ }^{134} \mathrm{Cs}$ & $1.3 \times 10^{3}$ & 40 & 0.005 & $2.0 \times 10^{-1}$ \\
\hline${ }^{129 m}-\mathrm{Te}$ & $1.1 \times 10^{3}$ & 33 & 0.005 & $1.6 \times 10^{-1}$ \\
\hline $127 \mathrm{~m}$ & $1.0 \times 10^{3}$ & 30 & 0.005 & $1.5 \times 10^{-1}$ \\
\hline${ }^{127} \mathrm{Te}$ & $1.0 \times 10^{3}$ & 30 & 0.005 & $1.5 \times 10^{-1}$ \\
\hline $85_{\mathrm{Kr}}$ & $9.6 \times 10^{2}$ & $2.9 \times 10^{2}$ & 1 & $2.9 \times 10^{2}$ \\
\hline $148 m_{p_{m}}$ & $9.1 \times 10^{2}$ & 2.7 & 0.005 & $1.4 \times 10^{-2}$ \\
\hline${ }^{129} \mathrm{Te}$ & $7.0 \times 10^{2}$ & 21 & 0.005 & $1.0 \times 10^{-1}$ \\
\hline${ }^{125} \mathrm{Sb}$ & $5.9 \times 10^{2}$ & 1.7 & 0.005 & $8.5 \times 10^{-3}$ \\
\hline${ }^{123} \mathrm{Sn}$ & $4.8 \times 10^{2}$ & 1.4 & 0.005 & $7.0 \times 10^{-3}$ \\
\hline $143 \mathrm{Pr}$ & $3.4 \times 10^{2}$ & 1.0 & 0.005 & $5.0 \times 10^{-3}$ \\
\hline $110_{\mathrm{Ag}}$ & $2.4 \times 10^{2}$ & $7.0 \times 10^{-1}$ & 0.005 & $3.5 \times 10^{-3}$ \\
\hline
\end{tabular}


TABLE III.14 (continued)

\begin{tabular}{|c|c|c|c|c|}
\hline Nuclide & $\begin{array}{c}\text { Concentration } \\
\text { (Ci/ton) } \\
\end{array}$ & $\begin{array}{l}\text { Quantity Released }(b, c) \\
\text { from Dissolver (Ci/hr) } \\
\end{array}$ & $\begin{array}{l}\text { Fraction Released } \\
\text { from Plant }(d) \\
\end{array}$ & $\begin{array}{l}\text { Quantity Released to } \\
\text { Environs ( } \mathrm{Ci} / \mathrm{hr} \text { ) }\end{array}$ \\
\hline $140_{\mathrm{Ba}}$ & $2.1 \times 10^{2}$ & $6.0 \times 10^{-1}$ & 0.005 & $3.0 \times 10^{-3}$ \\
\hline $125 \mathrm{~m} T \mathrm{e}$ & $1.3 \times 10^{2}$ & 4.0 & 0.005 & $2.0 \times 10^{-2}$ \\
\hline${ }^{154} \mathrm{Eu}$ & $9.3 \times 10^{1}$ & $2.8 \times 10^{-1}$ & 0.005 & $1.4 \times 10^{-3}$ \\
\hline $13 I_{I}$ & $9.0 \times 10^{-1}$ & $2.7 \times 10^{-1}$ & 0.5 & $1.4 \times 10^{-1}$ \\
\hline $129_{I}$ & $2.0 \times 10^{-3}$ & $6.0 \times 10^{-4}$ & 0.5 & $3.0 \times 10^{-4}$ \\
\hline $119 m_{s n}$ & 12.7 & $3.8 \times 10^{-2}$ & 0.005 & $1.9 \times 10^{-4}$ \\
\hline $115 m_{c d}$ & 10.7 & $3.2 \times 10^{-1}$ & 0.005 & $1.5 \times 10^{-3}$ \\
\hline 136 & I.1 & $4.5 \times 10=?$ & 0.005 & $2.3 \times 10^{-4}$ \\
\hline $113 \mathrm{~m}_{c d}$ & $9.2 \times 10^{-1}$ & $2.8 \times 10^{-2}$ & 0.005 & $1.4 \times 10^{-4}$ \\
\hline${ }^{124} \mathrm{Sb}$ & $5.5 \times 10^{-1}$ & $1.7 \times 10^{-3}$ & 0.005 & $8.5 \times 10^{-6}$ \\
\hline${ }^{131} \mathrm{Xe}$ & 1.3 & $4.0 \times 10^{-1}$ & 1 & $4.0 \times 10^{-1}$ \\
\hline $3_{H}$ & $2.5 \times 10^{1}$ & 7.5 & 1 & 7.5 \\
\hline${ }^{14} \mathrm{C}$ & $6.3 \times 10^{-2}$ & $2.1 \times 10^{-2}$ & 1 & $2.1 \times 10^{-2}$ \\
\hline $86_{\mathrm{Rb}}$ & $4.1 \times 10^{-1}$ & $1.7 \times 10^{-2}$ & 0.005 & $6.0 \times 10^{-5}$ \\
\hline${ }^{93} \mathrm{Zr}$ & $2.7 \times 10^{-1}$ & $8.1 \times 10^{-4}$ & 0.005 & $4.0 \times 10^{-6}$ \\
\hline $136_{B a}$ & $2.4 \times 10^{-1}$ & $7.2 \times 10^{-4}$ & 0.005 & $3.6 \times 10^{-6}$ \\
\hline $235 y$ & $1.2 \times 10^{-2}$ & $3.5 \times 10^{-5}$ & 0.005 & $1.8 \times 10^{-7}$ \\
\hline $236 u$ & $5.1 \times 10^{-2}$ & $1.5 \times 10^{-4}$ & 0.005 & $7.5 \times 10^{-7}$ \\
\hline $238_{U}$ & 30 & $9.0 \times 10^{-2}$ & 0.005 & $4.5 \times 10^{-4}$ \\
\hline $237_{\mathrm{Np}}$ & $2.3 \times 10^{-2}$ & $6.9 \times 10^{-5}$ & 0.005 & $3.5 \times 10^{-7}$ \\
\hline $238_{\mathrm{Pu}}$ & 34 & $1.0 \times 10^{-1}$ & 0.005 & $5.0 \times 10^{-4}$ \\
\hline${ }^{239} p_{u}$ & $1.1 \times 10^{2}$ & $3.3 \times 10^{-1}$ & 0.005 & $1.7 \times 10^{-3}$ \\
\hline${ }^{240} \mathrm{Pu}$ & 64 & $1.9 \times 10^{-1}$ & 0.005 & $0.5 \times 10^{-4}$ \\
\hline $24 i_{\mathrm{Pu}}$ & $7.2 \times 10^{3}$ & $2.2 \times 10^{1}$ & 0.005 & $1.1 \times 10^{-1}$ \\
\hline${ }^{242} \mathrm{pu}$ & $2.5 \times 10^{2}$ & $1.5 \times 10^{-1}$ & ถ. กิกรี & $38 \times 10^{-3}$ \\
\hline $241_{A m}$ & 13 & $3.9 \times 10^{-2}$ & 0.005 & $2.0 \times 10^{=4}$ \\
\hline $242 \mathrm{Am}$ & $7.1 \times 10^{-2}$ & $2.1 \times 10^{-4}$ & 0.005 & $1.0 \times 10^{-6}$ \\
\hline
\end{tabular}

(a) Mark IV fuel $(0.947 \% 235 \mathrm{U}$ initial enrichment) irradiated at $10 \mathrm{lW} /$ tonne to $2,500 \mathrm{MWd} /$ tonne, cooled 150 days after discharge from reactor.

(b) Uniform rate of release assumed from stari of fire to finish; fire assumed to burn for a minimum of $3 \mathrm{hr}$ and maximum. of $10 \mathrm{hr}$ at a rate of $0.3 \mathrm{ton} / \mathrm{hr}$ $(270 \mathrm{~kg})$.

(c) Releases from the dissolver at the estimated maximum temperature range of $2,400^{\circ}$ to $2,550^{\circ} \mathrm{F}\left(1,300^{\circ}\right.$ to $\left.1,400^{\circ} \mathrm{C}\right)$ are $100 \%$ for noble gases, $14 \mathrm{C},{ }^{3} \mathrm{H}$

(d) and halogens; $10 \%$ for isotopes of Te, $\mathrm{CS}, \mathrm{Ru}, \mathrm{Cd}, \mathrm{Rb} ; 1 \%$ for all others.

Release factors estimated to be the same for the path chrougin tine dissolver off-gas system ( $80_{\%}^{\prime \prime}$ of radionuclide flow) and the path through the main ventilation and filter system (20\%). 
TABLE III. 15

CALCULATED RADIATION DOSES FROM POSTULATED URANIUM METAL FIRE IN PUREX DISSOLVER

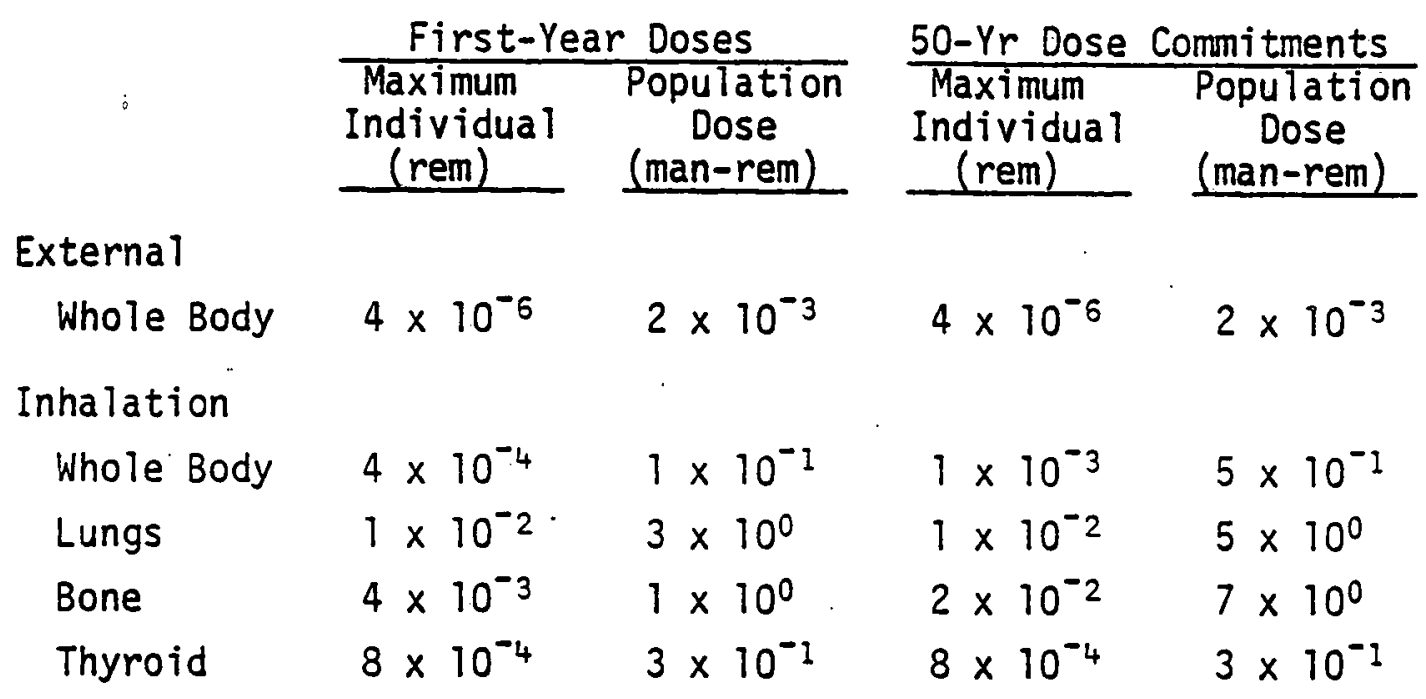

The flash point of $\mathrm{NPH}$ is $158^{\circ} \mathrm{F}\left(70^{\circ} \mathrm{C}\right)$ for vapor in air; however, for mists that could result from a pressure leak such as that postulated, flammability could occur at a temperature below $158^{\circ} \mathrm{F}$, depending on mist droplet size, temperature of the air in the cell, pressure, etc. ${ }^{(6)}$ The flash point for TBP is $295^{\circ} \mathrm{F}\left(146^{\circ} \mathrm{C}\right)$. The actual process solvent mixture has a higher flash point than NPH alone.

Although a pool of solvent such as that postulated to be on the floor of the cell would be extremely difficult to ignite, especially. at solvent temperatures below $140^{\circ} \mathrm{F}\left(60^{\circ} \mathrm{C}\right)$, it is assumed for purposes of this accident analysis that the flaming mist from the leak would ignite the solvent on the cell floor. Because the flash point of the solvent is $30^{\circ}$ to $50^{\circ} \mathrm{F}$ above the temperature of the solvent on the floor, the rate of burning (flame propagation) would be slow since it would be necessary for the heat of the fire to heat the liquid surface sufficiently to form a flammable vapor-air mixture before the flame would spread. 
According to the "Fire Protection Handbook, "( 7$)$ the solvent might be expected to burn at a rate of about six inches of depth per hour in a free-burning situation with an unrestricted flow of oxygen. This volumerate relationship in $G$ Cell would correspond to approximately $100 \mathrm{gpm}$. The free volume of $G$ Cell, that is, space not occupied by equipment, is about $45,000 \mathrm{ft}^{3}$ containing approximately $25 \mathrm{lb}$-moles of oxygen. This would be theoretically enough oxygen for a maximum of about four to five minutes of solvent combustion at the 100-gpm rate if. all the oxygen were usable. However, as the oxygen concentration drops to 10 percent or less in the course of the fire, combustion becomes increasingly difficult and not all of the oxygen can be consumed under actual conditions. The $G$ Cell ventilation flow rate of $7,000 \mathrm{cfm}$ represents only about 3.88 lb-moles of oxygen per minute and would sustain continued solvent combustion.at a rate of only about $5 \mathrm{gpm}$, again assuming complete use of all oxygen in the air stream. Furthermore, this normal ventilation flow would be somewhat reduced by the counter force of the fire draft, thus reducing further the amount of available oxygen and tending to shorten the duration of the fire. Therefore, a value of $50 \mathrm{gpm}$ is used as the combustion rate for the duration of this fire in estimating the consequences of this accident.

As noted above, several minutes would be required to build up to this rate. for purposes of this accident analysis, it is assumed that this rate would be approached (or reached) as the maximum before the heat produced would trigger the fire extinguisher system, even though this long delay wnuld be highly improbable.

The ftre suppression system in G Cell is the 3M "Light Water" foam automatic sprinkler system triggered by rate-of-rise temperature detectors. This will respond within 30 to 45 seconds after the heating rate reaches the appropriate level at the detector elements and will smother the fire completely within 15 to 30 seconds. The system applies foam automatically and simultaneously to the entire cell and to the adjoining ventilation 
tunnel. Based on the low initial combustion and heat generation rate, it is assumed that the foam system would not respond for the first four minutes, and thus the fire would burn for a total of five minutes at the maximum rate of 50 gallons of solvent per minute. Although such assumptions regarding combustion rates and responses are unrealistically conservative, they are used to define. the upper limit of severity of this accident.

The heat released into the ventilation tunnel from this postulated fire would raise the temperature of the full exhaust air flow at G Cell to about $750^{\circ} \mathrm{F}\left(385^{\circ} \mathrm{C}\right)$. At the main filter inlet, this temperature would be appreciably lower; thus, no significant damage or loss of filter efficiency would be expected unless the fire persisted for more than 15 to 20 minutes and if simultaneously the water sprays failed to work.

\section{Accident Preventives or Mitigating Conditions}

This accident has the potential for significant equipment and facility damage and some environmental contamination, particularly if the main ventilation filter efficiency were reduced. However, the probability of occurrence of a fire that would have major serious impact is very low for the following reasons:

- The G Cell liquid collection sump is equipped with a detector and alarm system that would normally signal a liquid accumulation that would be removed according to established operating procedures.

- Electrical overload detectors that are in service are designed to shut off pump motors automatically before conditions can be created. that would provide a solvent ignition source, such as overheated bearings.

- Electrical jumpers and in-cell electrical contacts are designed to prevent sparking. 
- Cell and tunnel are equipped with an automatic foam fire suppression system that responds when two detectors signal.

- The fire-fighting system includes an alarm in the central control room activated by any one detector unit; the operator on duty can then manualiy start the foam system.

- The solvent is difficult to ignite and slow to reach full burning rate.

- The amount and rate of burning would be appreciably restricted by the limited oxygen supply that would be further reduced by actions to cut the ventilation air flow to the minimum.

\section{Source Term for Postulated Solvent Fire in G Cell}

The solvent is the $1 \mathrm{CW}$ from the first extraction cycle containing the typical concentrations of radionuclides shown in Table III.16. The rest of the nuclides introduced with the irradiated fuels being reprocessed are essentially quantitatively eliminated with the aqueous raffinate (waste) in the first extraction cycle, and only trace quantities are carried into the solvent stream. The fractions of these radionuclides that would be volatilized as the solvent burned, or would be carried with the products of combustion and released into the ventilation tunnel, are also given in Table III.16. The releases shown are based on the combustion of a Inaximum of 250 gallons of solvent in the estimated five-minute interval before the fire would be extinguished.

On release into the main ventilation tunnel, the nuclides would become part of the total flow of $125,000 \mathrm{cfm}$ of air into the main filter and then to the exhaust stack. Filter efficiency is approximately 29.6 percent for particles of 0.7-micron aerodynamic mean diameter. Therefore, the estimated releases from filter to stack to plant environs are given based on a filter factor of $5 \times 10^{-3}$ for particulates. Filter efficiency of 50 percent is assumed for iodine. 
RHO-CD-742

TABLE III.16

RADIONUCLIDES RELEASED FROM POSTULATED

BURNING ORGANIC SOLVENT (ICW)

\begin{tabular}{|c|c|c|c|c|}
\hline $\begin{array}{l}\text { ICW. Sol } \\
\text { Nuclide }\end{array}$ & $\begin{array}{l}\text { ent Composition } \\
\text { Concentration(a) } \\
(\mathrm{Ci} / \mathrm{gal}) \\
\end{array}$ & $\begin{array}{r}\text { Fraction } \\
\text { Released } \\
\text { from Burning } \\
\end{array}$ & $\begin{array}{r}\text { Fraction } \\
\text { Released } \\
\text { from Plant } \\
\end{array}$ & $\begin{array}{l}\text { Quantity Released } \\
\text { to Environs (Ci) } \\
\text { (5-min release) } \\
\end{array}$ \\
\hline $238 \mathrm{U}$ & $1.2 \times 10^{-9}$ & 0.001 & 0.005 & $1.5 \times 10^{-12}$ \\
\hline & $2.2 \times 10^{-5}$ & 0.001 & 0.005 & $2.8 \times 10^{-8}$ \\
\hline & $8.3 \times 10^{-6}$ & 0.001 & 0.005 & $1.0 \times 10^{-8}$ \\
\hline${ }^{241} \mathrm{Pu}$ & $1.3 \times 10^{-3}$ & 0.001 & 0.005 & $1.6 \times 10^{-6}$ \\
\hline${ }^{95} \mathrm{Zr}$ & $2.8 \times 10^{-3}$ & 0.001 & 0.005 & $3.5 \times 10^{-6}$ \\
\hline${ }^{106} \mathrm{Ru}$ & $2.6 \times 10^{-3}$ & 0.5 & 0.005 & $1.6 \times 10^{-3}$ \\
\hline & $1.6 \times 10^{-6}$ & 0.001 & 0.005 & $2.0 \times 10^{-9}$ \\
\hline & $3.3 \times 10^{-7}$ & 0.5 & 0.005 & $2.0 \times 10^{-7}$ \\
\hline & $4.9 \times 10^{-4}$ & 0.001 & 0.005 & $6.1 \times 10^{-7}$ \\
\hline 129.1 & $6.1 \times 10^{-7}$ & 1.0 & 0.5 & $7.6 \times 10^{-5}$ \\
\hline $131_{I}$ & $2.3 \times 10^{-4}$ & 1.0 & 0.5 & $2.9 \times 10^{-2}$ \\
\hline
\end{tabular}

(a) Assumed 250 gallons burned in 5 minutes.

Calculated Radiation Doses From Postulated G Cell Solvent Fire

The calculated radiation doses and impacts of this accident are given in Table III.17 for the maximum offsite individual and for the population within a 50-mile radius of the Purex Plant.

\section{III.1.4.5 Postulated Nuclear Criticality in IBX Column}

This postulated accident assumes that through a combination of uniikely but possible circumstances, the amount of plutonium in the $1 \mathrm{BX}$ Column would steadily increase until the concentration reached the point at which $k_{\text {eff }}$ would equal or exceed unity and a nuclear criticality event would occur. 
TABLE III. 17

CALCULATED RADIATION DOSES FROM POSTULATED ORGANIC SOLVENT FIRE

\begin{tabular}{|c|c|c|c|c|}
\hline & \multicolumn{2}{|c|}{ First-Year Dose } & \multicolumn{2}{|c|}{ 50-Yr Dose Commi tments } \\
\hline & $\begin{array}{l}\text { Maxiliuiul } \\
\text { Individual } \\
\text { (rem) } \\
\end{array}$ & $\begin{array}{l}\text { Population } \\
\text { Dose } \\
\text { (man-rem) } \\
\end{array}$ & $\begin{array}{l}\text { Maximum } \\
\text { Individual } \\
\text { (rem) } \\
\end{array}$ & $\begin{array}{l}\text { Population } \\
\text { Dose } \\
\text { (man-rem) }\end{array}$ \\
\hline \multicolumn{5}{|l|}{ External } \\
\hline Total Body & $1 \times 10^{-8}$ & $3 \times 10^{-6}$ & $1 \times 10^{-8}$ & $3 \times 10^{-6}$ \\
\hline \multicolumn{5}{|l|}{ Inhalatiün } \\
\hline Total Body & $2 \times 10^{-7}$ & $2 \times 10^{-5}$ & $2 \times 10^{-7}$ & $2 \times 10^{-5}$ \\
\hline Lungs & $1 \times 10^{-5}$ & $1 \times 10^{-3}$ & $1 \times 10^{-5}$ & $2 \times 10^{-3}$ \\
\hline Bone & $3 \times 10^{-7}$ & $4 \times 10^{-5}$ & $6 \times 10^{-7}$ & $7 \times 10^{-5}$ \\
\hline Thyroid & $9 \times 10^{-5}$ & $1 \times 10^{-2}$ & $9 \times 10^{-5}$ & $1 \times 10^{-2}$ \\
\hline
\end{tabular}

The IBX Column is the partition column in which uranium and plutonium, as combined products in the organic solvent effluent from the first extraction column, are separated from each other. This is done by contacting a reducing agent (ferrous iron) that selectively reduces the valence of the plutonium, causing it to become relatively insoluble in the organic phase and transfer to the aqueous phase. The latter leaves the bottom of the column while the organic stream still carrying the. uranium leaves at the top of the column.

The 1BX Column is 34 inches in diameter and 33 feet, tall, and is not of favorable geometry for nuclear criticality prevention. Criticality prevention is accomplished by administrative controls, including specifications for stream flow rates and concentrations that, in turn, control the concentration and mass of plutonium in the column. Under normal conditions, the entering organic stream contains less than $0.13 \mathrm{~g}$ of plutonium per liter; this is stripped into the smaller volume aqueous phase, and is thus concentrated to about $0.85 \mathrm{~g}$ of plutonium per liter in the exit product stream (1BXP). At equilibrium, the column 
contains approximately 1,400 gallons $(5,300$ liters) of aqueous phase and 150 gallons (570 liters) of organic phase containing a combined total of 1,500 to $2,000 \mathrm{~g}$ of plutonium.

Before criticality could occur in this system, the concentration of plutonium would have to increase to at least $8 \mathrm{~g}$ per liter in the aqueous phase, a factor of 9 above the normal flowsheet concentration and a factor of 1.3 above the upper limit of nuclear criticality prevention specifications. This could occur as the unlikely result of reflux also unlikely - or an offstandard (low) flow of the IBXP stream. Reflux is a condition in which the entering plutonium is trapped in the column as process operation continues. This condition could result from an error in the composition of the standard 1BX stream combined with an excess of nitrite ion in the 1BXF feed stream, or from the use of a correctly prepared alternative reductant if the IBXF stream contained an excessive concentration of nitrite ion.

This could result in plutonium stripping, reoxidation by undestroyed nitrite ion present in the IBXF stream, reextraction and restripping in the first few feet above the bottom of the column (the disengaging section) and the resulting gradual buildup of plutonium in the aqueous phase at or near the bottom of the column, even if the organic and aqueous streams entering and leaving the column continued to flow normally.

The criticality in the $18 X$ Column is postulated to involve three 0.5-second bursts of $1 \times 10^{18}$ fissions each, over a period of 30 minutes. Ejection of part of the column contents, plus mixing and evaporation resulting from the bursts, would render the system subcritical and the bursts would cease.

Accident Preventives or Mitigating Conditions

This accident would have the potential for internal contamination of the Purex Plant cells and some equipment damage, plus releases of abnormal amounts of radioactive noble gases and halogens that would 
result in measurable offsite concentrations. However, the probability of occurrence is very low because of the following considerations:

- Process stream flow rates and plutonium concentrations are adjusted and controlled to mect process and eriticality prevention spectfications.

- Chemical solution preparations for the 1BX system are under administrative and chemical analytical controls as required by criticality prevention specifications.

- Stream flows and solution tank volumes are instrumentally monitored and continuously recorded in the central control room.

- Three external, vertically arranged neutron monitors are in place to survey the 1BX Column; these signal the central control room of any changes in plutonium concentration profile in the column. Increases in readings would indicate increases in plutonium concentration well in advance of reaching criticality, and would allow appropriate corrective action.

Source Term for Postulated Criticality in the 1BX Column

A. fission product buildup and decay computer program, (8) was used to compute the quantities of noble gases and iodines resulting from $10^{18}$ fissions occurring over a one-half-second interval. The results of this calculation were then scaled to yield the quantities of noble gases and iodines released to the atmosphere for the duration of the entire criticality event.

The quantities of most of the noble gases and iodines change rapidly during the first half-hour after fission, growing-in in some cases and decaying away in others. The quantities that would he released from $\checkmark$ Cell during this interval are estimated to be 50 percent of the iodines and 100. percent of the noble gases calculated to be present at a decay time of 15 minutes. Of the iodine released from $\mathrm{J}$ Cell, 50 percent would 
be deposited on surfaces contacted and in the exhaust and vent filters. Thus, only 25 percent of that formed in the three bursts would be released to the environment.

Source terms for calculating the population doses are derived by suming the quantities released for the three 0.5 -second bursts. The resulting amounts are listed in Table III.18.

\section{Calculated Radiation Doses from Postulated Criticality in IBX Column}

The calculated radiation doses and impacts that would result from this accident are given in Table III.19 for the maximum offsite individual and for the population within a 50-mile radius of the Purex Plant.

The IBX Column is in $\mathrm{J}$ Cell which has concrete walls six feet thick at the point of nearest employee approach. Because the criticality would occur inside the cell, the criticality incident alarms would not be triggered, and any employees in the storage gallery (the location nearest to the IBX Columnl. would be unaware that criticality had taken place until they were notified and told to leave.

Such employees, shielded by the concrete, would receive a very small radiation exposure estimated to be a maximum of $1 \times 10^{-6}$ rem (gamma) and $3 \times 10^{-3}$ rem (neutron) per burst. Assuming they remained in the gallery for the full 30 minutes, their total exposures would be $3 \times 10^{-6}$ rem and $9 \times 10^{-3}$ rem, gamma and neutron, respectively. No other employees would receive any discernible incremental exposure dose. 


\section{TABLE III. 18}

RADIONUCLIDES RELEASED FROM POSTULATED

NUCLEAR CRITICALITY IN IBX COLUMN

\begin{tabular}{|c|c|}
\hline Radionuclides & $\begin{array}{l}\text { Quantity Released to } \\
\text { Environs }(\mathrm{Ci})(\mathrm{a}) \\
\end{array}$ \\
\hline $83 m_{K r}$ & $1.1 \times 10^{1}$ \\
\hline $85 \underline{m}_{K r}$ & $4.8 \times 10^{1}$ \\
\hline${ }^{85} \mathrm{Kr}$ & $4.6 \times 10^{-4}$ \\
\hline $87 \mathrm{Kr}$ & $3.0 \times 10^{2}$ \\
\hline${ }^{88} \mathrm{Kr}$ & $1.9 \times 10^{2}$ \\
\hline${ }^{89} \mathrm{Kr}$ & $1.2 \times 10^{4}$. \\
\hline${ }^{129} \mathrm{I}$ & $1.7 \times 10^{-10}$ \\
\hline${ }^{131} \mathrm{I}$ & $5.5 \times 10^{-1}$ \\
\hline${ }^{132} \mathrm{I}$ & 2.0 \\
\hline${ }^{133} I$ & $1.1 \times 10^{1}$ \\
\hline${ }^{134} I$ & $1.4 \times 10^{2}$ \\
\hline${ }^{135} I$ & $3.7 \times 10^{1}$ \\
\hline $13 \underline{1 m}_{x e}$ & $1.2 \times 10^{-3}$ \\
\hline $133 \mathrm{~m}_{\mathrm{x}_{e}}$ & $1.6 \times 10^{-1}$ \\
\hline $133 x_{\theta}$ & 3.9 \\
\hline $135 m_{-x e}$ & $3.3 \times 10^{1}$ \\
\hline${ }^{135} \mathrm{xe}$ & $4.7 \times 10^{1}$ \\
\hline${ }^{137} \mathrm{Xe}$ & $1.1 \times 10^{4}$ \\
\hline${ }^{138} x_{e}$ & $3.6 \times 10^{3}$ \\
\hline $\begin{array}{l}\text { (a) Total fr } \\
\text { bursts o } \\
\text { assuming } \\
\text { noble ga } \\
\text { of iodin }\end{array}$ & $\begin{array}{l}\text { three } 0.5 \text {-second } \\
\text { rring in } 30 \text { minutes, } \\
0 \% \text { release of } \\
\text { and } 25 \% \text { release } \\
\text { rom the plant. }\end{array}$ \\
\hline
\end{tabular}


TABLE III.19

CALCULATED RADIATION DOSES FROM POSTULATED

CRITICALITY IN IBX COLUMN

\begin{tabular}{cc}
\multicolumn{2}{c}{ First. Year } \\
\hline $\begin{array}{c}\text { Maximum } \\
\text { Individual } \\
\text { (rem) }\end{array}$ & $\begin{array}{c}\text { Population } \\
\text { Dose } \\
\text { (man-rem) }\end{array}$ \\
\hline
\end{tabular}

50-Yr Dose Commitments

Maximum PopuTation

Individual Dose

(rem) (man-rem)

External

Total Body

$2 \times 10^{-4}$

$1 \times 10^{-1}$

$2 \times 10^{-4}$

$1 \times 10^{-1}$

Inhalation

$\begin{array}{lllll}\text { Total Body } & 4 \times 10^{-5} & 5 \times 10^{-3} & 4 \times 10^{-5} & 5 \times 10^{-3} \\ \text { Lungs } & 5 \times 10^{-4} & 7 \times 10^{-2} & 6 \times 10^{-4} & 7 \times 10^{-2} \\ \text { Bone } & 2 \times 10^{-4} & 2 \times 10^{-2} & 2 \times 10^{-4} & 2 \times 10^{-2} \\ \text { Thyroid } & 1 \times 10^{-2} & 2 \times 10^{\circ} & 1 \times 10^{-2} & 2 \times 10^{\circ}\end{array}$

\section{III.1.4.6 Postulated Cask Car Collision and Fuel Element Fire}

This postulated accident assumes that a loaded $\mathrm{N}$ Reactor fuel cask car would be involved in a collision with a petroleum fuel transport truck at the rail crossing near the northwest corner of the 200 East Area. The total weight of car, cask, fuel and water is approximately 400,000 pounds, making it unlikely that a broadside impact by the vehicle would overturn the rail car, but the impact could cause derailment which could then be followed by cask overturning.

Forces resulting from the cask overturning, plus the weight of the lid, plus the weight of fuel $(6,000$ pounds) in the cask were estimated to be great enough to cause at least one of the lid hasps to fail, with the result that the lid would be lost and the fuel elements spilled to the ground.

For the purpose of this accident analysis, it is assumed that some of the fuel elements would burn as the result of loss of water from the car well and cask followed by immersion in burning gasoline or diesel fuel from the truck. 


\section{Accident Preventives or Mitigating Conditions}

This would be a very serious accident that would have high potential for the radionuclide contamination of a sizable portion of the Hanford Reservation and for significant offsite contamination. However, the prubabilily of an uccurrence of this magnttude is very low due to the following considerations:

- Maximum speed of rail equipment at crossings is regulated.

- All trucks transporting petroleum fuels are required to stop at rail crossings.

- A collision involving a vehicle not transporting petroleum fuel would be unlikely to result in a motor fuel fire, which would thus greatly reduce the probability of burning the uranium and, in turn greatly reduce the releases of radionuclides.

- Brake failure on the vehicle at the exact time of the approach of a cask car to the crossing is an extremely improbable coincidence.

- Cask lid closures will be appreciably stronger in the future than the original design on which the hasp failure calculations were made.

Source Term for the Postulated Cask Car Collision and Uranium Fire

It is assumed that 0.1 ton of the fluel would burn in one hour before the fire is extinguished. Radionuclides would be released directly into the environment at the scene of the collision. The source term for the radionuclides released is given in Table III.20.

\section{Radiological Effects of Postulated Cask Car Accident}

Based on assumptions of particle sizes of the radionuclide oxides formed in the fire, rates of suspension and dispersion of the particles in the thermal plume, meteorological conditions and other pertinent variables, the radiation doses to the maximum individual and general public are calculated to be as given in Table III.21. 
TABLE III.20

RADIONUCLIDES RELEASED TO ENVIRONS FROM POSTULATED

CASK CAR COLLISION AND URANIUM FIRE

\begin{tabular}{|c|c|c|}
\hline Radionuclide & $\begin{array}{l}\text { Concentration } \\
(\mathrm{Ci} / \text { ton })(\mathrm{a}) \\
\end{array}$ & $\begin{array}{l}\text { Quantity Released to } \\
\text { Environs }(\mathrm{C} i)(\mathrm{b}, \mathrm{c})\end{array}$ \\
\hline${ }^{95} \mathrm{Nb}$ & $2.8 \times 10^{5}$ & $2.8 \times 10^{2}$ \\
\hline${ }^{144} \mathrm{Pr}$ & $1.9 \times 10^{5}$ & $1.9 \times 10^{2}$ \\
\hline${ }^{144} \mathrm{Ce}$ & $1.9 \times 10^{5}$ & $1.9 \times 10^{2}$ \\
\hline${ }^{95} \mathrm{Zr}$ & $1.5 \times 10^{5}$ & $1.5 \times 10^{2}$ \\
\hline $91{ }_{Y}$ & $1.1 \times 10^{5}$ & $1.1 \times 10^{2}$ \\
\hline${ }^{89} \mathrm{sr}$ & $7.2 \times 10^{4}$ & $7.2 \times 10^{1}$ \\
\hline $103 m_{\mathrm{Rh}}$ & $3.9 \times 10^{4}$ & $3.9 \times 10^{1}$ \\
\hline${ }^{103} \mathrm{Ru}$ & $3.9 \times 10^{4}$ & $3.9 \times 10^{2}$ \\
\hline${ }^{147} \mathrm{Pm}$ & $3.4 \times 10^{4}$ & $3.4 \times 10^{1}$ \\
\hline${ }^{106} \mathrm{Rh}$ & $3.3 \times 10^{4}$ & $3.3 \times 10^{1}$ \\
\hline${ }^{141} \mathrm{Ce}$ & $3.2 \times 10^{4}$ & $3.2 \times 10^{1}$ \\
\hline${ }^{137} \mathrm{Cs}$ & $1.1 \times 10^{4}$ & $1.1 \times 10^{2}$ \\
\hline $137 \underline{m}_{\mathrm{Ba}}$ & $9.9 \times 10^{3}$ & 9.9 \\
\hline${ }^{90} \gamma$ & $9.4 \times 10^{3}$ & 9.4 \\
\hline $90 s r$ & $3.4 \times 10^{3}$ & 9.4 \\
\hline $95 \underline{m}_{\mathrm{Nb}}$ & $1.9 \times 10^{3}$ & 1.9 \\
\hline${ }^{134} \mathrm{Cs}$ & $1.6 \times 10^{3}$ & $1.6 \times 10^{1}$ \\
\hline $129 \mathrm{~m}_{\mathrm{Te}}$ & $1.3 \times 10^{3}$ & $1.3 \times 10^{1}$ \\
\hline${ }^{127 m_{T e}}$ & $1.3 \times 10^{3}$ & $1.3 \times 10^{1}$ \\
\hline${ }^{127} \mathrm{Te}$ & $1.2 \times 10^{3}$ & $1.2 \times 10^{1}$ \\
\hline${ }^{85} \mathrm{Kr}$ & $1.1 \times 10^{3}$ & $1.1 \times 10^{2}$ \\
\hline${ }^{148 m_{p m}}$ & $1.1 \times 10^{3}$ & 1.1 \\
\hline${ }^{129} \mathrm{Te}$ & $8.3 \times 10^{2}$ & 8.3 \\
\hline${ }^{125} \mathrm{Sb}$ & $7.1 \times 10^{2}$ & $7.1 \times 10^{-1}$ \\
\hline${ }^{123} \mathrm{Sn}$ & $5.8 \times 10^{2}$ & $5.8 \times 10^{-1}$ \\
\hline${ }^{143} \mathrm{Pr}$ & $4.0 \times 10^{2}$ & $4.0 \times 10^{-1}$ \\
\hline${ }^{110} \mathrm{Ag}$ & $2.2 \times 10^{2}$ & $2.9 \times 10^{-1}$ \\
\hline $140_{\mathrm{Ba}}$ & $2.5 \times 10^{2}$ & $2.5 \times 10^{-1}$ \\
\hline
\end{tabular}


TABLE III.20 (continued)

\begin{tabular}{|c|c|c|}
\hline Radionuclide & $\begin{array}{l}\text { Concentration } \\
(\mathrm{Ci} / \text { ton })(\mathrm{a}) \\
\end{array}$ & $\begin{array}{l}\text { Quantity Released to } \\
\text { Environs }(\mathrm{C} i)(\mathrm{b}, \mathrm{c})\end{array}$ \\
\hline $125 \underline{m}_{T e}$ & $1.6 \times 10^{2}$ & 1.6 \\
\hline${ }^{154} \mathrm{Eu}$ & $1.1 \times 10^{2}$ & $1.1 \times 10^{-1}$ \\
\hline $131_{I}$ & .1 .1 & $1.1 \times 10^{-1}$ \\
\hline${ }^{129} \mathrm{I}$ & $2.5 \times 10^{-3}$ & $2.5 \times 10^{-4}$ \\
\hline $3_{H}$ & 30 & 3 \\
\hline${ }^{14} \mathrm{C}$ & $7.5 \times 10^{-2}$ & $7.5 \times 10^{-3}$ \\
\hline $235 U$ & $1.2 \times 10^{-2}$ & $1.2 \times 10^{-5}$ \\
\hline${ }^{236} U$ & $5.1 \times 10^{-2}$ & $5.1 \times 10^{-5}$ \\
\hline $238 u$ & 30 & $3.0 \times 10^{-2}$ \\
\hline${ }^{237} \mathrm{~Np}$ & $2.3 \times 10^{-2}$ & $2.3 \times 10^{-5}$ \\
\hline${ }^{238} \mathrm{Pu}$ & 34 & $3.4 \times 10^{-2}$ \\
\hline${ }^{239} \mathrm{Pu}$ & $1.1 \times 10^{2}$ & $1.1 \times 10^{-1}$ \\
\hline${ }^{240} \mathrm{Pu}$ & 64 & $6.4 \times 10^{-2}$ \\
\hline $241 \mathrm{Pu}$ & $7.2 \times 10^{3}$ & 7.2 \\
\hline${ }^{242} p_{11}$ & $2.5 \times 10^{2}$ & $2.5 \times 10^{-1}$ \\
\hline $241_{A m}$ & 13 & $1.3 \times 10^{-2}$ \\
\hline${ }^{242} \mathrm{Am}$ & $7.0 \times 10^{-2}$ & $7.0 \times 10^{-5}$ \\
\hline${ }^{242} \mathrm{Cm}$ & $1.5 \times 10^{2}$ & $1.5 \times 10^{-1}$ \\
\hline${ }^{244} \mathrm{Cm}$ & $4.0 \times 10^{-1}$ & $4.0 \times 10^{-4}$ \\
\hline \multicolumn{3}{|c|}{$\begin{array}{l}\text { (a) Mark I-A fue } 1 \text {, irradiated at } 11 \mathrm{MW} / \text { tonne to } \\
3,000 \text { MWd/tonne cooled } 150 \text { days after } \\
\text { discharge. } \\
\text { (b) Assumed } 100 \% \text { release of fisston gases, iodines, } \\
3 \mathrm{H} \text { and } 14 \mathrm{C} ; 10 \% \text { release of Te, Cs, Ru, Cd, Rb } \\
\text { isotopes; } 1 \% \text { release of all others (nonvolatiles) } \\
\text { that are not listed. } \\
\text { (c) Assumed } 0.1 \text { ton of fuel burned in } 1 \text { hour. } \\
\text { III-56 }\end{array}$} \\
\hline
\end{tabular}


TABLE III.21

CALCULATED RADIATION DOSES FROM POSTULATED

CASK CAR COLLISION AND URANIUM FIRE

\begin{tabular}{|c|c|c|c|c|}
\hline & \multicolumn{2}{|c|}{ First-Year Doses } & \multicolumn{2}{|c|}{ 50-Yr Dose Commitments } \\
\hline & $\begin{array}{l}\text { Maximum } \\
\text { Individual } \\
\text { (rem) }\end{array}$ & $\begin{array}{c}\text { Population } \\
\text { Dose } \\
\text { (man-rem) }\end{array}$ & $\begin{array}{l}\text { Maximum } \\
\text { Individual } \\
\text { (rem) }\end{array}$ & $\begin{array}{c}\text { Population } \\
\text { Dose } \\
\text { (man-rem) }\end{array}$ \\
\hline \multicolumn{5}{|l|}{ External } \\
\hline Total Body & $5 \times 10^{-4}$ & $1 \times 10^{-1}$ & $5 \times 10^{-4}$ & $1 \times 10^{-1}$ \\
\hline \multicolumn{5}{|l|}{ Inhalation } \\
\hline Total Body. & $5 \times 10^{-2}$ & $2 \times 10^{1}$ & $2 \times 10^{-1}$ & $8 \times 10^{1}$ \\
\hline Lungs & $2 \times 10^{0}$ & $7 \times 10^{2}$ & $3 \times 10^{0}$ & $9 \times 10^{2}$ \\
\hline Bone & $5 \times 10^{-1}$ & $2 \times 10^{2}$ & $3 \times 10^{0}$ & $1 \times 10^{3}$ \\
\hline Thyroid & $1 \times 10^{-1}$ & $4 \times 10^{1}$ & $1 \times 10^{-1}$ & $4 \times 10^{1}$ \\
\hline
\end{tabular}

III.2 URANIUM OXIDE PLANT

III.2.1 Radiological Impacts.

The capacity of the Uranium Oxide Plant is high enough that it can process an entire year's Purex Plant output in two short operating periods totaling about six to eight weeks. The probability of significant environmental impacts during this time and from this plant is very low. Refer to Section III.1.1.1 for discussion of general radiological impacts.

\section{III.2.1.2. Effluent Releases}

\section{Liquid Effluents}

Liquid releases during operations are cooling water, steam condensate, and chemical sewer waste sent to the 216-U-10 Pond and process condensate sent to the 216-U-12 Crib. 
Actual releases during 1972 and projected annual releases from 1983 on, are given in Table III.22. The 1973 to present period is not given because the plant has not been operated during the Purex Plant shutdown.

TABLE I11.2L

ACTUAL AND ESTIMATED LIQUID WASTE RELEASES

FROM THE URANIUM OXIDE PLANT (a)

\begin{tabular}{|c|c|c|c|c|}
\hline Year & $\begin{array}{c}\text { Cooling Water } \\
\text { (gal) } \\
\end{array}$ & $\begin{array}{c}\text { Process } \\
\text { Condensate } \\
\text { (gal) } \\
\end{array}$ & $\begin{array}{c}\text { Tota } \\
\text { Beta (Ci) }\end{array}$ & $\begin{array}{l}\text { Tota } 1 \\
\text { Uranium }(\mathrm{kg})\end{array}$ \\
\hline \multirow[t]{2}{*}{1972} & $1.2 \times 10^{8}$ & & 1.6 & 6.5 \\
\hline & & $1.0 \times 106$ & $<0 . \overline{1} 1$ & $<0.06$ \\
\hline \multirow[t]{2}{*}{$1983-1984$ (b) } & $1.2 \times 10^{8}$ & & $<3.5$ & $<4.3$ \\
\hline & & $9.8 \times 10^{5}$ & $<0.01$ & $<0.06$ \\
\hline
\end{tabular}

(a) Numbers designated as "less than" (<) are, or are derived from, values of the lower limits of detection.

(b) Al though startup could be delayed, these values represent the probable annual maximum through $N$ Reactor shutdown in 7990 . Annual amounts will probably decrease in future years as the accumulated fuel inventory is reprocessed.

The chemical sewer carries air compressor cooling water, spilled chemicals, floor flushes, etc., to the 216-U-10 Pond. This waste averages about $1 \times 10^{7} \mathrm{gal} / \mathrm{yr}$ and generally contains trace quantit.ips of uranium and nitric acid.

All of these releases represent less than 10 percent of the actinides and less than 50 percent of the total beta curies routinely released in liquids to ground in the 200 West Area. Their contribution, both actual and potential, to radiation exposure of the general public is essentially zero. 
Gaseous Effluents

The actual releases during 1972 and the projected annual releases from 1983 on are given in Table III.23. The 1973 to present period is not included because the plant has not been operated during that time.

\section{TABLE III.23}

ACTUAL AND ESTIMATED GASEOUS WASTE RELEASES FROM THE URANIUM OXIDE PLANT

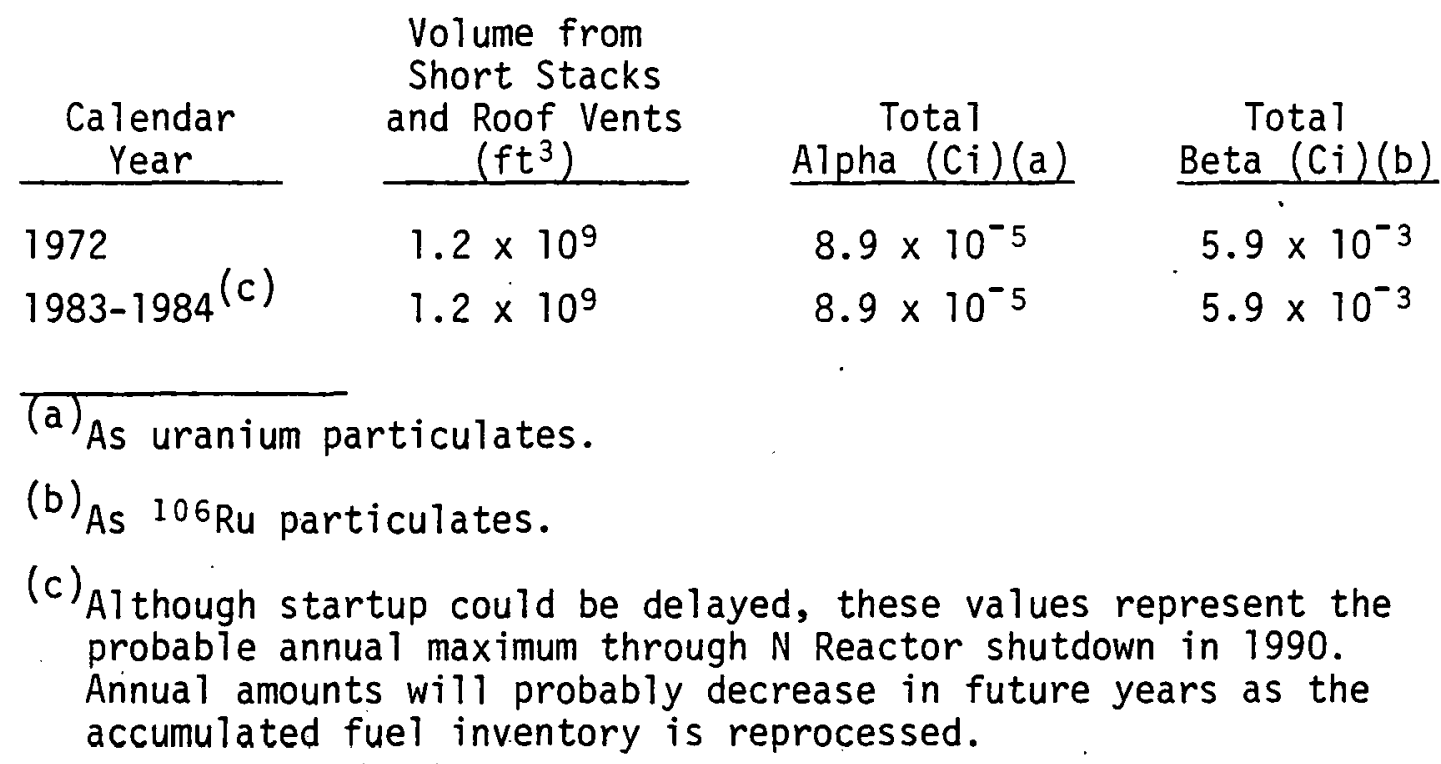

Concentrations, total amounts and operating periods are small in relation to overall 200 Areas operational releases; the incremental impact of the Uranium Oxide Plant discharges is indiscernible.

\section{III.2.1.3 Solid Waste}

In calendar year 1972, approximately $740 \mathrm{ft}^{3}$ of mixed fission product waste from the Uranium 0xide Plant was buried in the 200 West Area industrial burial ground. This waste represented approximately $0.5 \mathrm{Ci}$ of total beta emitters and less than $0.03 \mathrm{Ci}$ of combined ${ }^{90} \mathrm{Sr},{ }^{13} 7 \mathrm{Cs}$ and ${ }^{106} \mathrm{Ru}$ nuclides. It contained $950 \mathrm{~g}$ of total uranium.

No solid waste was discharged in the period 1973 to present while the plant was not in operation. 
Future plant operations will produce approximately the same amounts and types of solid waste as in 1972.

\section{III.2.1.4 Occupational Doses to Employees}

The total complement of workers when the Uranium Oxide Plant is in full operation is approximately 30, including operations, maintenance and supervision. In 1971 to 1972, the annual average whole body occupational radiation dose of the Uranium Oxide Plant workers was approximately 1 rem; the maximum was 2.3 rem and the minimum was 0.09 rem.* However. because this plant operated only part of the time, the process operations workers were assigned elsewhere for more than half of the operating year. Thus, the annual exposure actually acquired in the Uranium 0xide Plant operation averaged less than 0.5 rem per employee.

In future operations, the Uranium Oxide Plant will be operated in sequence with B Plant and Purex Plant. This will mean a full work force at Uranium Oxide for only about two months of the year and a standby force of only about five people for the rest of the year. The anticipated result of this part-time operation plus the periodic personnel relocation, will be a reduction in Uranium Oxide Plant-related radiation exposure per emplnyẹe to about 30 to 40 percent of the 1971 to 1972 leveis. These exposures will be reduced further by continuation of the current radiological improvement program designed and operated to maintain radiation exposures at levels as low as reasonably achievable.

\section{III.2.2 Nonradiological Impacts}

\section{III.2.2.1 Effluent Releases}

\section{Liquid Effluents}

Sanitary water is used at an average rate of $50 \mathrm{gpm}$ during plant operations. It serves toilets, showers, drinking fountains, lunchrooms, etc., and is disposed of to a septic tank-tile field near U Plant.

ÆSee Section III.1.1.4 for recommended 1imits. 
The $1.2 \times 10^{8} \mathrm{gal} / \mathrm{yr}$ of cooling water discharged to the $216-4-10$ Pond is released over two relatively short periods totaling approximately six to eight weeks. However, the volume is a relatively smail fraction (less than 10 percent) of the annual total received in this pond and has no discernible impact on the pond or the underlying groundwater system.

\section{Gaseous Effiuents}

The gaseous discharge from the stack venting the nitric acid absorber averages 3,600 cfm when all six calciners are in operation. This discharge contains about 3,000 to $4,000 \mathrm{ppm}$ oxides of nitrogen $\left(\mathrm{NO}_{\mathrm{X}}\right)$. At these concentrations, occupational $\mathrm{NO}_{x}$ exposures at ground level are normally below $1 \mathrm{ppm}$ on an hourly average. However, 30-second peak concentrations are estimated to exceed 5 ppm under adverse meteorological conditions which are expected to prevail less than five percent of the time. Based on the six to eight-week-long annual operating periods, this represents an average occurrence frequency rate of once or twice per operating campaign.

The continuous air samplers (Section III.1.1.2) used at Purex Plant for monitoring $\mathrm{NO}_{x}$ concentrations will be moved to the Uranium Oxide Plant in accordance with the sequential operating mode. The TLV for an eight-hour working day is 5 ppm.

At the nearest Hanford Reservation boundary seven miles west of the 200 West Area, the $\mathrm{NO}_{x}$ concentration in the acid absorber effluent is reduced by dispersion and dilution by factors of from $10^{6}$ to $10^{8}$. Therefore, the Uranium Oxide Plant $\mathrm{NO}_{x}$ concentration in the atmosphere at that point would be less than $0.004 \mathrm{ppm}$ compared with the nonoccupational exposure limit of $0.05 \mathrm{ppm}$ annual average concentration for continuous breathing.

As in the case of the Purex Plant, $\mathrm{NO}_{x}$ releases from the Uranium Oxide Plant have probably exceeded the 20 percent opacity standard. 
Thus, studies are required to determine what modifications to existing equipment and processes might be appropriate or necessary to reduce future $\mathrm{NO}_{x}$ emissions to achieve compliance with the opacity standard. It will also be necessary to develop the relationship between opacity (NO $x$ concentrations) of a colored gas and the measurement techniques and opacity standard (currently applied by the Benton-Franklin-Walla Walla Counties Air Pollution Control Authority) which were originally designed to apply only to particulates such as mists and fly ash.

Since approximately 92 percent. nf the nitrogen oxides frnm the calcination step are recovered as nitric acid, the release of $\mathrm{NO}_{2}$ averages about 50 pounds per ton of $\mathrm{UO}_{3}$ produced. For 1983-1984, this will represent approximately 25 to 30 tons of $\mathrm{NO}_{2}$ discharged to the environs, compared with an estimated total of 760 tons of $\mathrm{NO}_{2}$ to be discharged from the 200 Area powerhouses for the same period.

The operation of the Uranium Oxide Plant will add a small incremental coal consumption to the 200 West Ared powerhouse load and will give a related increase in pollutant emissions to the atmosphere. However, the operating periods are short - totaling only six to eight weeks per year - and steam consumption when the plant is operating is only $10,000 \mathrm{lb} / \mathrm{hr}$. (1ess than 10 percent of Purex Plant usage rate). Thus, the increments are very small and are within the normal limits of variation in coal usage and particulate emissions.

\section{III.2.2.2 Solid Waste}

Ordinary trash (primarily paper) is compacted to approximately onethird volume and buried in the Hanford Reservation central sanitary 1andfil1. The Uranium Oxide Plant output is negligible in comparison with the $360,000 \mathrm{ft}^{3} / \mathrm{yr}$ total for all of the Hanford Reservation. 


\section{III.2.3 Natural Forces}

The 224-U Building was built in the period 1943 to 1949, preceding the inclusion of seismic provisions in the UBC. It was designed for static loads and vertical live and dead loads; design calculations were performed manually. Lateral wind forces, based on projected area, were included in the designs. During this period, Hanford was designated as a low-intensity, minimum-occurrence earthquake zone. Thus, only small lateral earthquake design forces related to the mass of the structure were considered. The 224-UA Building was built according to the UBC, which contained seismic provisions, with Hanford designated as Zone 2, based on deductions from historical records, implying moderate damage. Lateral wind forces were included in the design of both buildings, based on the maximum straight lateral wind forces experienced in the recorded history of the region. (See Section III.1.3 of this report and ERDA-1538, Section III.2.11, for additional information on natural forces. :

\section{III.2.4 Accident Impacts}

The uranium oxide operation more closely resembles a normal industrial plant than any of the other chemical processing operations in the 200 Area facilities. The decontaminated uranyl nitrate being processed contains less radioactivity than aged natural uranium because the decay product elements have been removed by the Purex process. Even the most serious accident that can be postulated would have essentially no radiological risks for, or discernible impacts on, the public or on employees in excess of established limits for annual occupational radiation exposure.

Many possible accidents were considered including those that have occurred in the course of past operations (Section III.2.4.1). The accidents listed and surmarized in Tables III.24 and III.25 have not. been analyzed further because they would be obviously less serious than the massive spill discussed in Section III.2.4.2, which, in turn, would 


\section{HISTORICAL ACCIDENTS IN THE URANIUM OXIDE PLANT}

\section{Date Brief Description of the Accident}

4-12-60 Uranium trioxide powder was being loaded into large shipping containers through a flexible hose connection between the hopper and container. The hose broke and spilled about 1.5 tons of uranium oowder nver the nutsine nf the container and onto the loadout pad. The powder spread over the asphalt loading ramp and to the road around the $\mathrm{UO}_{3}$ facility. inost of the powder was swept up and put in drums for recovery, but the rest of the powder was washed off the asphalt and onto the ground surface. Contaminated soil was removed and buried as waste:

1-10-61 The tank truck used to transport the uranyl nitrate solution from Purex to the 224-U Bulloing left the 224-U Bullding with uranium solution dripping onto the roadway. The contamination was removed from the road and truck.

5-4-62 UnH solution was tranșferred from tne 224-J 8uilding through a line, mistakenly believed to be blocked, into the idle 22l-U Building sump collection tank and thence to an outside holdup and sample tank. A small amount of the solution overflowed the tank into the 216-U-1 Crib. The rest was returned by tank car to the process for recovery.

5-10-68 The uranyl nitrate tanker was received at the 224-IJ Building with the pump discharge vaive and the cupold drain valve open. Road and truck were cleaned and returned to service.
Estimared Release and Environmental impacts

Contamination was 1 imited to the immediate areas of the spill. There was no general spread in 200 West Area and no detectable contamination offsite.

Spots of contamination up to 4,000 counts/min were found along the truck's path from U Plant to the 200 fast Area. There wererno private automotive vehicles contaminated, and ño offsite contamination was found. The contaminated spots were estimated to cover a total of about $100 \mathrm{ft}^{2}$ of highway.

ilo contanination was relezsed to the piant environs or offsite. Probably less than 500 ib (225 kg) of uranium was released to underground soil.

Streaks of concamination were tound at each nighway curve between Purex and $224-4$ juilding. with readings up to 3,000 countsinin. The conianination was removed with no eviuence oj any further spread onsite or ofisite. A cotal ruadway area of approxinately $200 \mathrm{it}^{2}$ was contaninated. 


\section{TABLE III.25}

\section{CONCEIVABLE ACCIDENTS POSTULATED}

FOR THE URANIUM OXIDE PLANT

\section{Postulated Accident Description and Cause}

"Red oil" explosion in 100\% UNH concentrator in $D$ cell caused by failure of administrative and procedural controls to prevent organic solvent from entering the concentrator. Entire volume of UNH ejected.

Failure of a primary exhauster bag filter in the $\mathrm{UO}_{3}$ powder handling system caused by split seams in the bag or the bag coming loose from its mounting clamps.

Leak of UNH from 203-U storage tanks, via faulty valve or corrosion-caused failure; also possible leak of UNH transfer line at faulty connection or line break.

Maloperation of nitric acid absorber, resulting from low flow of cooling water or absorber tower water. Tenfold increase in $\mathrm{NO}_{2}$ release to atmosphere for a short period (up to an hour) before recovery or shutdown.
Potential Environmental Consequences

Release to atmosphere of a maximum of $100 \mathrm{lb}(45 \mathrm{~kg})$ of uranium through "hatch cover" on roof of cell plus personnel access door at ground level. Contamination of immediate plant environs but little, if any, discernible spread offsite.

Release of a few pourds of finely divided $\mathrm{UO}_{3}$ dust through the secondary exhauster, the glass fiber filter, and out the stack to the atmosphere. Contamination of immediate plant environs but little, if any, discernible spread offsite.

Solution would be largely retained in 203-U enclosure and returned to the process. Some minor leakage to the soil, plus some evaporation and minor spread of UNH dust would result. No significant airborne transfer of the uranium away from the immediate plant area and no discernible offsite contamination would be expected.

Release of oxides of nitrogen to the atmosphere in amounts resulting in ground level concentrations above those from normal operations and above established working limits ( $5 \mathrm{ppm}$ for $8 \mathrm{hr}$ ) for employees. Maximum $\mathrm{NO}_{x}$ concentrations at Hanford Reservation boundary estimated to be well below established upper 1 imit (0.05 ppm) for unlimited exposure. No discernible radionuclide releases to plant personnel or to the public. 
be far less serious than the postulated accidents of the Purex Plant and of the waste management accidents in ERDA-1538.

Operations in the Uranium Oxide Plant are conducted according to formal process specifications and standards under formal operating procedures and safety rules. To determine quality of performance and degree of compliance, periodic internal audits and appraisals are conducted by independent technical, managerial and quality assurance contractor personnel. Formal training programs for operating personnel are in place, documented and audited.

Following any accident or potentially serious abnormal event in the plant, a thorough review is conducted to learn its causes, to establish the requirements for prevention of a repeat accident in future operations, and to profit where possible by applying the information from the investigation to other aspects of the 200 Area operations. Based on experience plus design and operating reviews, any operability problems involving process and/or equipment breakdowns that can occur will be correctable within the established limits of radiation exposure and safety standards and requirements.

A thorough study of the plant and its fire protection system was made by the Factory Mutual Engineering Association in 1973. No major deficiencies were noted, and no major recommendations were made. Fire extinguisher and hydrant protection was found to be adequate. Administrative control was considered adequate.

\section{III.2.4.1 Historical Accidents}

Abnormal events have occurred in the course of Uranium Oxide Plant operations, which have resulted in loss of control and containment of the radionuclides in process. The material being proccssed has such a low specific activity, as Table III.26 shows, that releases of even large quantities have had no discernible radiological impact on the 
environment. No evidence of offsite contamination from this plant operation has ever been found. Past accidents are summarized in Table III.24.

\section{TABLE III.26}

\section{RADIONUCLIDES RELEASED FROM POSTULATED URANIUM OXIDE SPILL}

\begin{tabular}{|c|c|c|}
\hline Radionuclide & $\begin{array}{l}\text { Concentration } \\
\left(\mathrm{Ci} / \mathrm{g} \text { of } \mathrm{UO}_{3}\right)\end{array}$ & Total Release ( $\mathrm{C}$ ) \\
\hline${ }^{103} \mathrm{Ru}$ & $8.8 \times 10^{-12}$ & $2.8 \times 10^{-10}$ \\
\hline${ }^{106} R u-R h$ & $5.9 \times 10^{-10}$ & $1.9 \times 10^{-8}$ \\
\hline $95_{Z r-N b}$ & $2.0 \times 10^{-9}$ & $6.4 \times 10^{-8}$ \\
\hline${ }^{238} \mathrm{Pu}$ & $2.8 \times 10^{-11}$ & $9.0 \times 10^{-10}$ \\
\hline${ }^{239} \mathrm{Pu}$ & $8.0 \times 10^{-11}$ & $2.6 \times 10^{-9}$ \\
\hline $240 \mathrm{Pu}$ & $4.2 \times 10^{-11}$ & $1.3 \times 10^{-9}$ \\
\hline${ }^{241} \mathrm{Pu}_{\mathrm{u}}$ & $3.6^{\prime} \times 10^{-9}$ & $1.2 \times 10^{-7}$ \\
\hline $242 \mathrm{pu}$ & $1.2 \times 10^{-14}$ & $3.8 \times 10^{-13}$ \\
\hline $235 U$ & $1.4 \times 10^{-8}$ & $4.5 \times 10^{-7}$ \\
\hline $238_{U}$ & $2.7 \times 10^{-7}$ & $8.6 \times 10^{-6}$ \\
\hline
\end{tabular}

III.2.4.2 Postulated Spill of Large Quantity of Uranium Oxide

Where tonnage quantities of $\mathrm{UO}_{3}$ powder are routinely handled, the potential exists for a major spill. This can happen both inside and outside the buildings in a number of different ways, involving different aspects of the uranium oxide operations. Despite precautions in process and equipment design and operating procedures, gross spills and losses of control have occurred, as noted in the preceding section.

In this postulated accident, a pallet loaded with four 55-gallon drums, each containing approximately 1,500 pounds of unmilled $\mathrm{UO}_{3}$ 
powder, would be dropped from the forklift truck during transfer from loadout to storage. It is assumed that the impact plus the crushing effect of the uppermost drums, would knock the lids off or rupture one or more drums. In addition to the "puff" of powder ejected into the air by the force of the impact release, it is assumed that about 1,000 pounds of the powder would be spilled in a pile onto the pavement near the 224-UA Loadout Station. Following the initial large concentration of dust loading in the air from the burst, a constant sweep of air at 33 feet per second (typical of a moderately windy Hanford day) would continue to pick up and carry off $\mathrm{UO}_{3}$ powder from the spill until the pile of material was retrieved and packaged.

\section{Accident Preventives or Mitigating Conditions}

The postulated accident, although a Uranium Oxide Plant contamination problem of potentially significant proportions, would not be a serious accident environmentally. Very little, if any, uranium oxide would be transported offsite, and there would be virtually no probability of demonstrable contamination of the public sector from the spill.

Probability of the occurrence of such an accident is low, but is considered to be higher than the serious accidents postulated to occur at the Purex Plant. The following considerations reduce the accident potential and seriousness:

- Operators are trained in the proper use and handling of forklifts, including requirements for forklift inspection and maintenance to minimize the chance of mechanical failure.

- Potential load imbalance and shifting are minimized by banding the four drums on the pallet together.

- Most of the spilled powder would be picked up immediately by operating personnel who wear respiratory protection and protective outer clothing. 
- Any residual uranium oxide would be washed off the pavement onto the soil which would then be removed for recovery of the uranium or burial.

- The uranium oxide is radiologically less hazardous than aged natural uranium, and would represent no significant hazard to employees or the public.

- The powder is dense and not easily transported any significant distance by air currents; because it is unmilled, the particles are relatively large and the proportion of "fines" is small.

Source Term for Postulated Uranium Oxide Spill

The unmilled $\mathrm{UO}_{3}$ powder contains not more than one percent (and probably much less) of particles fine enough to become airborne. In the spilled powder this would be a maximum of 10 pounds $(4,500 \mathrm{~g})$. For the purpose of this analysis, it is assumed that this fine material is all of respirable size, i.e., all one micron aerodynamic mean diameter. It is also assumed that complete cleanup of the spill would be accomplished within three hours. Experiments $(9)$ indicate that one percent of this material could be suspended by a $20-\mathrm{mph}$ wind in a 24-hour period. Also, 70 percent of the 24-hour release would occur within the first three hours. The total release for the uranium oxide spill is, therefore, estimated to be 0.7 percent of the 10 pounds, or 32 grams of $\mathrm{UO}_{3}$. The composition of the uranium oxide, and the total release are given in Table III.26.

Radiological Consequences of Postulated $\mathrm{UO}_{3} \mathrm{Spill}$

Dose calculations for the postulated uranium oxide spill are given in Table III.27. 
RHO-CD-742

TABLE III.27

CALCULATED RADIATION DOSES FROM URANIUM OXIDE SPILL

\begin{tabular}{|c|c|c|c|c|}
\hline & \multicolumn{2}{|c|}{ First Year Doses } & \multicolumn{2}{|c|}{ 50-Yr Dose Commitments } \\
\hline & $\begin{array}{l}\text { Maximum } \\
\text { Individual } \\
\text { (rem) }\end{array}$ & $\begin{array}{l}\text { Population } \\
\text { Dose } \\
\text { (man-rem) }\end{array}$ & $\begin{array}{l}\text { Maximum } \\
\text { Individual } \\
\text { (rem) }\end{array}$ & $\begin{array}{c}\text { Population } \\
\text { Dose } \\
\text { (man-rem) }\end{array}$ \\
\hline \multicolumn{5}{|l|}{ External } \\
\hline Whole Body & $3 \times 10^{-13}$ & $2 \times 10^{-10}$ & $3 \times 10^{-13}$ & $2 \times 10^{-10}$ \\
\hline \multicolumn{5}{|l|}{ Inhalation } \\
\hline Whole Body & $4 \times 10^{-8}$ & $7 \times 10^{-5}$ & $5 \times 10^{-8}$ & $1 \times 10^{-5}$ \\
\hline Lungs & $1 \times 10^{-5}$ & $4 \times 10^{-3}$ & $3 \times 10^{-5}$ & $1 \times 10^{-2}$ \\
\hline Bone & $4 \times 10^{-7}$ & $1 \times 10^{-4}$ & $8 \times 10^{-7}$ & $2 \times 10^{-4}$ \\
\hline Thyroid & 0 & 0 & 0 & 0 \\
\hline
\end{tabular}




\section{REFERENCES FOR SECTION III}

1. Seismic Analysis of the Purex Facility Process Building, ARH-R-220, URS/John A. Blume and Associates, Engineers, San Francisco, California, December 1976.

2. Additional Seismic Analyses of the Purex Facility Process Building, RHO-R-3, URS/John A. Blume and Associates, Engineers, San Francisco, California, October 1977.

3. Conservatism of $\mathrm{N}$ Reactor Design Criteria for Earthquake Protection, DUN 5143, H. S. Davis, Douglas United Nuclear, Inc., Richland, Washington, December 1968.

4. Seismic Review of 291-A Filter Cells 1 and 2, ARH-R-216, URS/John A. BTume and Associates, Engineers, San Francisco, California, June 1976.

5. Tritium Control Technology, WASH-1269, Monsanto Research-Mound Laboratory for Division of Operational Safety, December 1973, p. 414.

6. J. Eichhorn, "Carefully - Mists Can Explode", Petroleum Refiner 34; pp. 194-196, 1955.

7. Fire Protection Handbook, 13th Edition, National Fire Protection Association, 1969, p. 5-26.

8. R. 0. Gumprecht, Mathematical Basis of Computer Code RIBD, Douglas United Nuclear, Inc., Richland, Washington, June 1968.

9. J. Mishima and L. C. Schwendiman, Some Experimental Measurements of Airborne Uranium (Representing Plutonium) in Transportation Accidents, BNWL-1732, Battel7e, Pacific Northwest Laboratories, Richland, Washington, August 1973. 
U.S. Department of Energy

Richland Operations Office

\section{J. Elgert (15)}

Rockwell Hanford Operations

D. C. Bartholomew

B. F. Campbe 11

D. J. Cockeram

R. R. Eqqleston

R. J. Gimera

R. D. Hammond

W. M. Harty, Sr.

W. F. Heine

J. E. Kinzer

L. M. Knights

H. P. Shaw

R. Shropshire

R. W. Szempruch

Central Files

Rockwell Document Services 